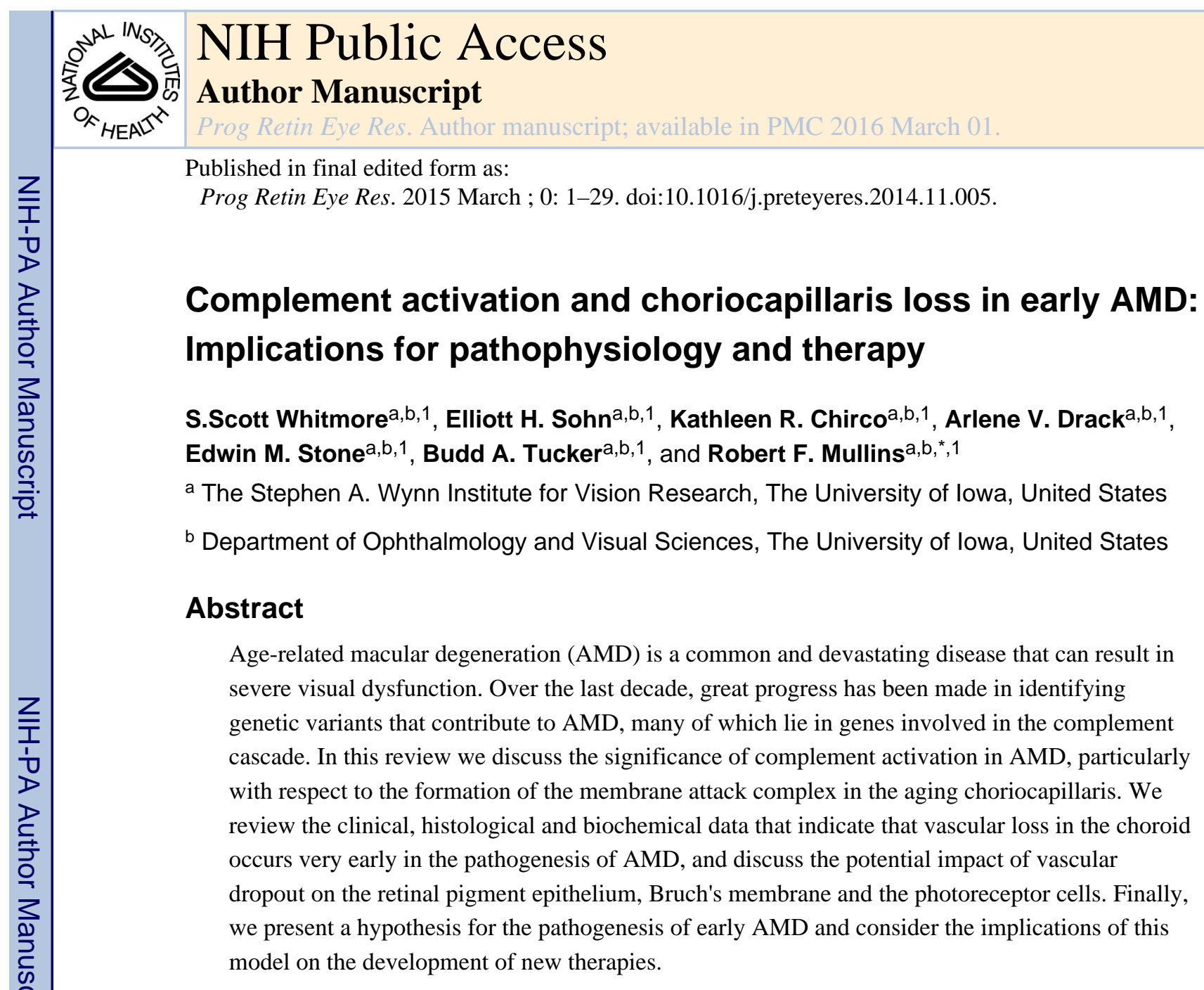

\title{
Keywords
}

Age-related macular degeneration; Choroidmacula; Complement system; Endothelial cells; Choriocapillaris; Pathophysiology

\section{Age-related macular degeneration}

\subsection{Overview of AMD}

Age-related macular degeneration (AMD) is the leading cause of irreversible vision loss in the elderly, affecting millions in the US alone (Friedman et al., 2004). Its etiology is complex in nature and consists of pathologic degeneration of the central retina, termed the macula (Latin: spot), associated with current or imminent vision loss due to advanced age. The macula and its foveal center, the area with highest density of cone photoreceptor cells, mediate fine visual acuity allowing for activities like driving and recognizing faces. Onset of

\footnotetext{
(C) 2014 Elsevier Ltd. All rights reserved.

* Corresponding author. Department of Ophthalmology and Visual Sciences, The Stephen A. Wynn Institute for Vision Research, The University of Iowa, 4130 MERF, 375 Newton Rd, Iowa City, IA 52242, United States..

${ }^{1}$ Percentage of work contributed by each author in the production of the manuscript is as follows: Whitmore: $25 \%$, Sohn: $11 \%$,

Chirco: 10\%, Drack: 7\%, Stone: 7\%, Tucker: 10\%, Mullins: $30 \%$.

Uncited reference

Cruickshanks et al., 2001.
} 
AMD typically occurs after age 50 and prevalence increases with advancing age. Vision loss associated with AMD adversely affects quality of life (Mangione et al., 1999) as patients have a higher incidence of depression (Casten and Rovner, 2013) and activity often becomes limited due to fear of falling (van Landingham et al., 2014; Wang et al., 2012b). The socioeconomic burden from AMD on health care systems (Brechner et al., 2011; Coleman and $\mathrm{Yu}, 2008$ ), family members, and caretakers is substantial (Gupta et al., 2007; Soubrane et al., 2007).

Broadly, AMD is grouped into three primary forms that are determined from ophthalmoscopic examination: early nonexudative ('dry'); late non-exudative ('atrophic'); and exudative or neovascular ('wet'). Patients with early dry AMD typically have little to no central vision loss but exhibit drusen and/or retinal pigment epithelial (RPE) changes in the macula. Permanent scotoma correlate to areas of cell loss in geographic atrophy (GA) associated with the more advanced form of dry AMD. Decreased visual acuity occurs when GA involves the fovea but it usually takes years (to decades) after diagnosis of early AMD to occur. Dry AMD is the default pathway for AMD and currently has no cure. A minority of AMD patients will convert to the wet form, in which choroidal neovascularization (CNV) leaks fluid, exudate, and/or hemorrhages under the retina causing acute vision loss. Intravitreal anti-vascular endothelial growth factor (VEGF) treatments stabilize most eyesand improve vision in some-but requires repeated administration that can last years.

\subsection{Classification of AMD}

Proposed clinical grading schemes for AMD are based on funduscopic examination of the macula (Bird et al., 1995; Davis et al., 2005; Ferris et al., 2005; Klein et al., 1991; Ferris et al., 2013). As a high proportion of elderly have at least a few small, hard drusen without subsequent development of vision threatening macular degeneration, the term age-related maculopathy has been used to encompass all forms of pathologic changes in the macula associated with advanced age.

In 1995, an International Consortium classified the various forms of age-related maculopathy and proposed a system based on a standard grid using stereoscopic $30^{\circ}$ fundus photographs centered on the fovea (Bird et al., 1995; Klein et al., 1991):

- grading of drusen is performed based on morphology, size, extent, and location

- hyperpigmentation and hypopigmentation of the RPE is noted by presence and location

- GA is distinctly different from hypopigmentation of the retina (discussed below) but accounts for presence, location, and area covered

- neovascular AMD looks at typifying features (e.g. subretinal hemorrhage, retinal pigment epithelial detachment), location, and area covered by the CNV. Presence of CNV reclassifies any eye with GA as neovascular AMD (Bird et al., 1995).

The age-related eye disease study (AREDS) group subsequently proposed a phenotypic scoring system (full (Davis et al., 2005) and simplified (Ferris et al., 2005)) for AMD severity that approximates 5 year risk of developing advanced AMD. The AREDS report no. 
8 (Age-Related Eye Disease Study Research Group, 2001) detailed which patients are most likely to have a significant risk reduction in developing CNV with AREDS-formula vitamins (see subsequent section) by stratifying dry AMD into the following categories:

1. None or $\sim 5-15$ small ( $\$ 33 \mu \mathrm{m}$ sized) drusen without pigment abnormalities

2. >15 small drusen or at least 1 intermediate $(63-125 \mu \mathrm{m})$ druse

3. $~ 20$ intermediate drusen or at least 1 large $(\geq 125 \mu \mathrm{m})$ druse; no drusen needed if non-center involving GA is present

4. Second eye with advanced AMD (CNV or center-involving GA)

This classification is notable to practicing clinicians because the recommendation for starting AREDS-formula vitamins in a patient with AMD was found to be significant for patients in category 3 or greater. Experiments suggesting a mechanism of action for AREDS-formula vitamins are discussed in Section 3 below.

The above-described classifications for AMD are based solely on ophthalmoscopic findings on clinical examination or manual grading of fundus photographs, potentially failing to detect relevant subretinal pathology observable using more recent high-resolution imaging modalities. In addition, an active area of investigation is drusen detection using automated analysis of fundus photos and/or OCT images (Niemeijer et al., 2007; Quellec et al., 2011a, 2011b).

\subsection{Early AMD and drusen}

Pathological changes involving choroid, Bruch's membrane (BrM), RPE, and photoreceptor cells have all been implicated in early and late stages of AMD.

As noted above, early AMD is characterized by RPE pigmentation abnormalities and the presence of drusen. Drusen are ophthalmoscopically visible lesions, characterized by appearance (Fig. 1). Their size, number, density, and fluorescence are highly symmetric between eyes within an individual (Barondes et al., 1990). Hard drusen tend to be well delineated and less than $63 \mu \mathrm{m}$ (i.e. small). Soft drusen can have distinct or indistinct borders and can range from small to large ( $\geq 125 \mu \mathrm{m})$ in size. Soft indistinct drusen are more prevalent in the temporal and superior quadrants whereas pigmentary changes occur more frequently in the superior and nasal quadrants of the macula (Wang et al., 1996).

Histologically, drusen accumulate within Bruch's membrane, between the RPE basal lamina and the inner collagenous layer of Bruch's membrane (Russell et al., 2000), following Hogan's five layer definition of Bruch's membrane (Hogan et al., 1971).

A very substantial fraction of formed drusen components consists of esterified cholesterol and phosphatidylcholine, components likely released by the RPE (Wang et al., 2010a). Additional components include complement proteins, apolipoproteins, MHC antigens and other pro-inflammatory molecules (Hageman et al., 2001; Crabb et al., 2002; Johnson et al., 2001; Mullins et al., 2000). As noted by Curcio and colleagues, the genetic contribution to AMD of genes involved in lipid trafficking and processing (discussed below) is consistent with the lipid composition of drusen, and has important implications for AMD pathogenesis (Pikuleva and Curcio, 2014). 
Size and number of soft drusen carry the greatest prognostic significance for vision loss from AMD (Davis et al., 2005; Ferris et al., 2005). Additional risk factors for progression to advanced AMD include confluence of drusen within $1600 \mu \mathrm{m}$ of the foveal center, RPE alterations and slow choroidal filling on fluorescein angiography (Holz et al., 1994). Hard drusen, common to elderly, by themselves do not characterize AMD (Bird et al., 1995).

Drusen are sometimes misnamed with variants due to their high prevalence in elderly eyes and similar appearance on funduscopic examination. Cuticular drusen, best seen in the early arteriovenous phase of the fluorescein angiogram as a 'starry sky' appearance, look clinically similar to hard drusen. First described by Gass (Gass et al., 1985), histologically they are similar to typical drusen (Russell et al., 2000). Cuticular drusen are common in patients with missense mutations in fibulin-5 and those with high-risk Tyr402His alleles in complement factor H (CFH) (Grassi et al., 2007; Stone et al., 2004). Subretinal drusenoid deposits, also known as reticular pseudodrusen and reticular drusen, look clinically similar to soft, confluent drusen, but are readily distinguished from typical drusen by their appearance internal to the RPE (i.e., between the RPE and photoreceptor cells) on OCT and histology (Arnold et al., 1995; Zweifel et al., 2010a, 2010b).

The importance of photoreceptor cell integrity in visual function is highlighted in eyes with advanced dry AMD, where vision loss is commonly known to be associated with areas overlying geographic atrophy (Hogan, 1972; Sarks, 1976). In these cases, photoreceptor loss is thought to be due to atrophy of the underlying RPE. Three notable studies using OCT to characterize photoreceptor cells in eyes with GA confirmed loss of photoreceptors in these regions. Notably, for a number of eyes there appeared to be significant photoreceptor cell loss in areas overlying intact RPE that were clinically normal (Bearelly et al., 2009; Fleckenstein, 2008; Wolf-Schnurrbusch et al., 2008). The disposition of the choroid was not determined in these patients.

Interestingly, rod-mediated dark adaptation changes occur early in age-related maculopathy (Owsley et al., 2007). Delay in rod-mediated dark adaptation has also been seen in elderly adults with normal fundus examinations and known risk factors for AMD, including elevated CRP (discussed below) (Owsley et al., 2014). It appears that photoreceptor cell (particularly rods) loss occurs in the AMD disease process, although this has been suggested to follow the accumulation of subRPE deposits (Jackson et al., 2014).

\subsection{Advanced AMD: geographic atrophy}

GA is clinically defined as any sharply delineated, roughly round or oval areas of hypopigmentation or apparent absence of RPE in which choroidal vessel are more visible than in surrounding areas for at least $175 \mu \mathrm{m}$ in diameter (Bird et al., 1995) (Fig. 2). The Beaver Dam Study found the 15 year incidence of developing GA in eyes with early AMD is $13.5 \%$ (Klein et al., 2007). While the incidence of neovascular AMD was higher than that of pure GA in young persons, the incidence of GA was 4 times that of neovascular AMD in persons $>85$ year of age. GA can be diagnosed by ophthalmoscopic examination but measurement and monitoring for progression requires photography, autofluorescence, and/or OCT imaging (Kanagasingam et al., 2014). Annual growth rate of GA per year is $1.78 \mathrm{~mm}^{2}$ but can vary based on a number of factors including size/ number of drusen and baseline 
size of lesion. Visual acuity is often decreased prior to development of GA, and a decline of over 4 ETDRS lines may be seen on average over 5 years (Lindblad et al., 2009).

GA is often observed after collapse of pigment epithelial detachments (Casswell et al., 1985; Cukras et al., 2010), areas of drusen regression, and hypopigmentation and hyperpigmentation (Klein et al., 2008). Histology of human donors with GA show thinning or absence of the RPE, atrophy of the choriocapillaris, and degeneration of overlying photoreceptors (Sarks et al., 1988). Both photoreceptor loss (Bird et al., 2014) and choroidal thinning (Sohn et al., 2014b) have been observed in GA maculas outside of the area of atrophy. Early studies of giant cells, macrophages, and other immunocompetent cells in atrophic AMD foreshadowed later developments linking the immune system to AMD (Penfold et al., 1986, 1985).

There is currently no treatment for GA itself, though patients may have a risk reduction in CNV with AREDS formulation vitamins (Age-Related Eye Disease Study 2 Research Group, 2013; Age-Related Eye Disease Study Research Group, 2001). There are a number of clinicaltrials underway for GA that includes visual cycle modulation [NCT01802866 on clinicaltrials.gov], doxycycline [NCT 01782989 on clinicaltrials.gov], complement inhibition such as anti-factor D (Do and Pieramici, 2014), and cell-based transplantation. Since GA involves loss of multiple tissue layers, cell replacement therapy is likely to require a complex reconstruction.

\subsection{Advanced AMD: choroidal neovascularization}

Neovascular AMD is defined as the presence of choroidal vascularization (CNV), which can manifest clinically as exudate, intraretinal fluid, subretinal fluid and/or hemorrhage (Fig. 3). It may also manifest as pigment epithelial detachment and disciform scarring. Prevalence is estimated at $10 \%$ of eyes with AMD (Ferris et al., 1984).

Patients often present with blurred vision and distortion (Fine et al., 1986) and, if properly counseled and compliant, may notice changes detectable by Amsler grid home-monitoring (Folk, 1985) or by peripheral hyperacuity perimetry (AREDS2-HOME Study Research Group et al., 2014).

Untreated, visual decline secondary to CNV can be devastating and was the most frequent cause of legal blindness in the elderly (Ferris et al., 1984; Friedman et al., 2004). The most frequently identified modifiable risk factor for advanced AMD is cigarette smoking (Seddon et al., 1996); however, associations have been made with genetics (see below), obesity (Howard et al., 2014), diet (Age-Related Eye Disease Study Research Group, 2001; Eye Disease Case-Control Study Group, 1993; Seddon et al., 2003), and cardiovascular risk factors (Hyman et al., 2000). AREDS-formula vitamins are recommended to patients with at least category 3 nonneovascular AMD to reduce the risk of CNV by approximately $30 \%$ (Age-Related Eye Disease Study 2 Research Group, 2013; Age-Related Eye Disease Study Research Group, 2001).

Prior to the widespread use of OCT (Huang et al., 1991) approximately 10-15 years ago, fluorescein angiography was a mainstay for diagnostic imaging as this determined treatment

Prog Retin Eye Res. Author manuscript; available in PMC 2016 March 01. 
eligibility for Macular Photocoagulation Study (MPS) laser (Macular Photocoagulation Study Group, 1982, 1993). OCT is now routinely performed to diagnosis and follow treated eyes with CNV due to its high sensitivity, ease of use, and rapid fluid detection in the retina, sub-retinal and sub-RPE space (Keane et al., 2012).

Outcomes of eyes sustaining CNV have improved dramatically since the advent of antiVEGF therapy 8 years ago (Brown et al., 2006; Rosenfeld et al., 2006, 2005). Intravitreal injections of ranibizumab, bevacizumab (CATT Research Group et al., 2011) or aflibercept (Bakall et al., 2013; Heier et al., 2012) are standard of care for neovascular AMD and have prevented visual impairment and legal blindness in a significant number of patients (Bressler et al., 2011). Photodynamic therapy is also an FDA approved treatment for CNV (Treatment of Age-related Macular Degeneration With Photodynamic Therapy (TAP) Study Group, 1999; Verteporfin In Photodynamic Therapy Study Group, 2001) but is usually employed only in anti-VEGF injection-resistant cases (Tozer et al., 2013).

\section{Genetics of AMD}

\subsection{Background}

AMD is a complex disease, with both environmental (e.g., diet and smoking) (Age-Related Eye Disease Study Research Group, 2001; Seddon et al., 1994, 2001b; Christen et al., 1996; SanGiovanni et al., 2007; Seddon et al., 1996; Vingerling et al., 1996) and genetic risk factors. The notion that AMD is an inherited disease was discussed at least as early as the 1970s, when Gass noted the similarities between clearly familial drusen and "senile" drusen (Gass, 1973). Consistent with this idea, the rates of AMD have been found to vary widely between different ethnic groups (Congdon et al., 2004; Grassi et al., 2006). The proportion of AMD risk attributable to one's ancestry has previously been estimated at between 45 and $70 \%$ (Seddon et al., 2005) with environmental exposures comprising the remainder of the risk.

Prior to the completion of a map of the human genome, candidate gene approaches were employed to identify rare, highly penetrant variants associated with AMD (Stone et al., 2004). These included attempts to extend discoveries of genes associated with rare, early onset Mendelian forms of macular degeneration such as Stargardt disease (Allikmets et al., 1997; Guymer et al., 2001), Sorsby fundus dystrophy (Weber et al., 1994; Tymms, 1999), auto-somal dominant radial drusen (Heon et al., 1996) and Best disease (Seddon et al., 2001a; Lotery et al., 2000), reviewed in (Sohn et al., 2013). Whether variants in Mendelian maculopathy genes cause a detectable fraction of AMD has been somewhat controversial in the field.

In addition to candidate gene studies, genome-wide scans, using available molecular markers, revealed a risk locus in AMD patients on chromosome 1q (Klein et al., 1998; Weeks et al., 2001). The identity of the variant(s) and responsible gene(s) would be confirmed after the creation of new tools from the human genome project.

With the success of the human genome project and the identification of millions of relatively common single nucleotide polymorphisms (SNPs) that differ between individuals, the

Prog Retin Eye Res. Author manuscript; available in PMC 2016 March 01. 
feasibility of discovering genetic associations using genome wide association studies became much greater. In 2005, four essentially simultaneous papers were published ( 3 in Science and one in Proceedings of the National Academy of Science) identifying a SNP in complement factor $\mathrm{H}(\mathrm{CFH})$ as a major genetic risk factor for AMD (Edwards et al., 2005; Haines et al., 2005; Klein et al., 2005; Hageman et al., 2005). Other studies soon followed supporting the CFH finding (Zareparsi et al., 2005), and also implicating variants in LOC387715 (later named ARMS2 for age-related maculopathy susceptibility 2) as the second major genetic risk locus for AMD (Jakobsdottir et al., 2005; Rivera, 2005). With these two major risk loci identified, a host of replication studies followed along with candidate gene approaches focused on the complement pathway (i.e., the molecular pathway that includes $\mathrm{CFH}$ ).

To date, the most comprehensive meta-analysis of thirty-three AMD cohorts identified nineteen loci as associated with AMD at genome-wide significance (Fritsche et al., 2013). The following section summarizes our knowledge of the CFH, ARMS2, and other AMD associated loci and explores potential impact on AMD pathogenesis.

\subsection{Complement factor $H$}

The discovery of $\mathrm{CFH}$ as the chromosome 1 risk factor in AMD was a major paradigm shift in our thinking about this disease. In many ways, the CFH variant is the "perfect storm" for molecular genetics. The difference in frequency between cases and controls is very high-in initial studies, the allele frequency for the risk allele was nearly twice as high in cases as controls, indicating a large effect size. Second, the risk allele is common in the initially studied populations (an overall frequency of $\sim 38 \%$ ). These two features made the detection of the risk allele possible in even a relatively small series of cases and controls (Edwards et al., 2005), whereas SNPs with smaller effect size and lower frequency require thousands of cases and controls (e.g. (Fritsche et al., 2013)). Third, the observation that the variant is in a member of the complement system was consistent with previous histopathologic studies that noted that complement system genes were excellent candidates for AMD, given the appearance of these components in drusen (Johnson et al., 2000; Mullins et al., 2000, 2001). Finally, the main variant (that encodes a tyrosine to histidine substitution) was itself very plausibly functional, in contrast to the vast majority of SNPs identified in association studies that are in intergenic regions or in non-coding sequences of genes.

The $\mathrm{CFH}$ gene encodes the full length $\mathrm{CFH}$ protein, composed of twenty complement control protein (CCP) domains, and the shorter splice-isoform CFH-like 1 (CFHL-1), composed of CCP1-7. CCP1-4 and CCP19-20 bind C3b, the pro-inflammatory breakdown product of C3. CCP6-8 and CCP16-20 bind C-reactive protein (CRP) (Okemefuna et al., 2010), and CCP7 and CCP20 bind malondialde-hyde (Weismann et al., 2011). While both CCP6-8 and CCP19-20 can bind sulfated GAGs, CCP6-8 preferentially binds heparan sulfate in Bruch's membrane while CCP20 binds heparan sulfate in glomerular basement membrane of the kidneys (reviewed in (Langford-Smith et al., 2013)). The Y402H polymorphism lies within CCP7, whereas variants associated with kidney disease are primarily found in CCP19-20. 
Within the CFH locus, the rs 10737680 single-nucleotide polymorphism (SNP) was most strongly associated with AMD in the recent meta-analysis (Fritsche et al., 2013); however, this SNP was not in linkage disequilibrium with rs1061170, the well-studied tyrosine to histidine change at position 402 in the pro-peptide (Y402H polymorphism) (Fritsche et al., 2013), consistent with previous reports. CFH risk alleles also show stronger association with AMD in individuals of European ancestry (Fritsche et al., 2013). Moreover, the frequency of the $\mathrm{Y} 402 \mathrm{H}$ allele does not correlate well with the frequency of AMD across ethnicities, even when considering other risk factors for AMD, suggesting that other genetic factors may modify the impact of this allele in disease pathogenesis (Grassi et al., 2006). As efficacy of complement activation appears to be influenced by several variants in complement components (Heurich et al., 2011), determining population frequencies of these variants in multiple ethnicities may explain the non-correlation between $\mathrm{Y} 402 \mathrm{H}$ frequency and AMD prevalence across ethnicities.

The $\mathrm{Y} 402 \mathrm{H}$ genotype has been shown to enhance systemic complement activation. Markers of chronic complement activation, $\mathrm{C} 3 \mathrm{~d}$ and $\mathrm{Ba}$, were strongly elevated in plasma of AMDaffected individuals compared with age-matched controls, and to a lesser extent C3a, C5a, and SC5b-9 (Scholl et al., 2008). Furthermore, the $C F H$ risk genotypes increase systemic complement activation independent of AMD diagnosis (Scholl et al., 2008). Analysis of joint risk between pairs of loci identified $C F H$ and $C 2-C F B$ as significant after multiple hypothesis testing correction (Fritsche et al., 2013). Systemic complement activation as measured by increased complement breakdown products $(\mathrm{C} 3 \mathrm{~d} / \mathrm{C} 3 \mathrm{~b}$ ratio) was associated with the $C F H$ risk alleles (Smailhodzic et al., 2012). As discussed below, individuals homozygous for the $\mathrm{Y} 402 \mathrm{H}$ polymorphism show increased choroidal C-reactive protein (Johnson et al., 2006). Using a recombinant CFH protein, Ormsby et al. found that the $\mathrm{Y} 402 \mathrm{H}$ variant reduces binding of $\mathrm{CFH}$ and $\mathrm{CCP} 1-7$ (used as a proxy for CFHL-1) to CRP, with greater impairment for CCP1-7, possibly as a consequence of containing one less binding domain than the full length protein (Ormsby et al., 2008). Similarly, Y402H in both CFH and CFHL-1 reduces binding with group A streptococcal protein M6 (Ormsby et al., 2008), a protein which facilitates the streptococcal evasion from complement attack.

The Y402H risk polymorphism reduces CFH and CFHL-1's ability to bind tissue-specific glycosaminoglycan moieties in the extra-cellular matrix. Using three partial $\mathrm{CFH}$ constructs (CCP19-20, CCP6-8 402H, and CCP6-8 402Y), Clark et al. found that the CCP6-8 $402 \mathrm{Y}$ shows much greater binding affinity for Bruch's membrane than do the two other constructs (Clark et al., 2013). CFH binding to oxidation-modified products is also reduced by the $\mathrm{Y} 402 \mathrm{H}$ polymorphism. The $\mathrm{Y} 402 \mathrm{H}$ allele reduces the ability of $\mathrm{CFH}$ to bind malondialdehyde adducts, potentially reducing the clearance of apoptotic cells (Weismann et al., 2011). Similarly, the variant reduces binding of CFH to oxidized phospholipids, a possible byproduct of light exposure and strongly aerobic environment of the posterior pole (Shaw et al., 2012). The risk genotype also increases circulating oxidative phospholipid levels in non-AMD subjects (Shaw et al., 2012). The cumulative effect on CFH function is not limited to the eye, as $\mathrm{Y} 402 \mathrm{H}$ has been associated with reduced longevity in a cohort of Finnish nonagenerians (Jylhävä et al., 2009). 


\subsection{The ARMS2/HTRA1 locus}

In 2005 a second locus was identified along with CFH as strongly associated with risk for AMD (Dewan et al., 2006; Jakobsdottir et al., 2005; Rivera, 2005; Yang et al., 2006). Initially the locus was reported as spanning from PLEKHAl to HTRA1 (PRSS11); however, further studies have refined the interval. The risk haplotype contains the A69S coding change within the first exon of ARMS2 (LOC387715), a SNP within the ARMS2 intron, a complex indel overlapping the polyadenylation site in the $3^{\prime}$ UTR of ARMS2, an intergenic SNP, a SNP in the promoter of HTRAl, and a SNP in the first intron of HTRAl (Fritsche et al., 2008). Near complete linkage disequilibrium between variants within ARMS2 with variants in the promoter of and first intron of HTRAl have confounded attempts to pinpoint the causal variant within the risk haplotype (Richardson et al., 2010; Yasuma et al., 2010), although SNPs in ARMS2 have higher statistical association in a number of reports (e.g., (Anderson et al., 2010)).

HTRAl (High temperature requirement A serine peptidase 1) encodes a protease that cleaves multiple extracellular matrix proteins. Expression of HTRA1 protein in the retina has been reported to increase in AMD-affected eyes (Tuo et al., 2008), and HTRAl mRNA has been reported to be increased in AMD-affected maculas (Chan et al., 2007). HTRA1 has been implicated in TGFB mediated retinal angiogenesis in mice (Zhang et al., 2012b). The promoter SNP has been reported to increase expression of HTRA1 mRNA levels (Yang et al., 2006), but this finding was not replicated in other studies (Friedrich et al., 2011; Kanda et al., 2007). Therefore, although HTRA1, as a protease, is functionally plausible as a gene that could contribute to breakdown of Bruch's membrane, studying samples with high-risk HTRAl promoter variants has not consistently shown an effect on HTRA1 levels, raising doubts as to the functional importance of HTRA1 in AMD.

ARMS2 is a small, two exon primate-specific gene with no homology to other sequences (Rivera, 2005), and age-related macular drusen formation is linked to variants in ARMS2 and HTRAl in rhesus macaques (Francis et al., 2008). Two splicing isoforms have been reported (Wang et al., 2012a). The Ala69Ser (A69S) risk allele and the $3^{\prime}$ UTR complex indel have both been scrutinized for possible functional impacts. Like the Y402H variant in CFH, ARMS2 is an attractive candidate because the risk allele is an amino acid substitution in the putative protein. Whereas ARMS2 mRNA is present in placenta (Jakobsdottir et al., 2005; Rivera, 2005), transcriptional evidence in other tissues has been contradictory (Jakobsdottir et al., 2005; Rivera, 2005; Wang et al., 2012a, 2013). Conflicting reports have localized ARMS2 protein to the extracellular matrix of choroidal pillars (Kortvely et al., 2010), inside the mitochondria (Fritsche et al., 2008; Kanda et al., 2007) or within the cytosol (Wang et al., 2009a). These discrepancies may be due to different combinations of antibodies, cell lines, and donor tissue. Another study found that the complex deletion reduced ARMS2 mRNA stability (Fritsche et al., 2008); however, this was not replicated in (Wang et al., 2013). Knockdown of ARMS2 transcripts in ARPE-19 cells lowered expression of the proinflammatory genes C3, C5, IL-6, IL-8, and TNF-a (Zeng et al., 2013), but until localization of ARMS2 is resolved, the relevance of these findings remains uncertain. 
Until experimental systems are devised to disentangle each variant in the haplotype, the effects of ARMS2 and HTRA1 polymorphisms may best be considered as a unit. A metaanalysis of this region has shown that other variants may also contribute to AMD risk, although complete haplotype mapping for those variants was not available (Yu et al., 2013). Evidence supports a statistical interaction between smoking and the ARMS2/HTRA1 risk genotype leading to increased AMD risk (Schmidt et al., 2006). AMD-affected individuals homozygous for the ARMS2/HTRA1 risk genotype showed increased plasma carboxyethylpyrrole biomarker levels as compared to AMD-affected individuals homozygous for the non-risk genotype (Gu et al., 2009). One 2013 report found that $C F H$ and ARMS2 genotypes showed differential response to AREDS vitamin and zinc supplementation (Awh et al., 2013); however, a later report examining the same dataset did not support this conclusion, likely due to more stringent analytical criteria (Chew et al., 2014). Unlike risk genotypes of $C F H, C F B$, and $C 3$, the $A R M S 2 / H T R A 1$ risk haplotype strongly correlates with risk for bilateral AMD (Schwartz et al., 2012). Evidence for a genegene interaction between $C F H \mathrm{Y} 402 \mathrm{H}$ and ARMS2 A69S has been described in a Finnish population (Seitsonen et al., 2008).

In contrast to $C F H$ association with geographic atrophy, risk alleles in ARMS2/HTRA1 associate more strongly with choroidal neovascularization in most (Deangelis et al., 2008; Fritsche et al., 2013; Sobrin et al., 2011) but not all studies (Tuo et al., 2008). The A69S haplotype is also associated with polypoidal choroidal vasculopathy in the Japanese population (Gotoh et al., 2009, 2010), and increased expression of human HTRA1 in mouse RPE leads to a PCV-like phenotype (Jones et al., 2011).

One surprising finding, in light of the lack of known function for $A R M S 2$, is that individuals homozygous for the ARMS2/HTRAl risk haplotype show significantly elevated serum CRP levels as compared to individuals homozygous for the low-risk haplotype in a cohort of Japanese individuals over the age of 60 without evidence of AMD (Yasuma et al., 2010). The 10q locus has also been found to be associated with increased plasma complement metabolites, independent of CFH genotype (Smailhodzic et al., 2012). These results suggest that the ARMS2/HTRA1 locus may play a role in inflammation and influence the complement cascade.

\subsection{Other complement genes associated with AMD}

In addition to $C F H$ and $A R M S 2$, several other genes have been associated with risk for AMD, particularly in the complement cascade. A two-stage gene association study genotyping a total of 1287 individuals identified two haplotypes spanning $C 2$ and $C F B$ that conferred protection against AMD (Gold et al., 2006). A second study examining 2172 individuals over 60 years of age supported the two allele finding, proposing the protective haplotypes had independent evolutionary origins (Maller et al., 2006). No epistatic interaction between the $C 2-C F B$ haplotypes and either $C F H$ and $A R M S 2$ was observed (Maller et al., 2006). The 2013 meta-analysis ranked the $C 2$-CFB locus as the third strongest association by odds ratio and $p$-value and supported an interactive effect between a variant near $C 2-C F B$ and the $C F H$ locus (Fritsche et al., 2013). Two alleles of complement component three $(C 3)$, differentiated by an arginine to glycine change of amino acid 80 , 
exhibit "slow" (80R) and "fast" (80G) migration by electrophoresis. In a study of three UK cohorts totaling 1548 individuals, the $80 \mathrm{G}$ allele was shown to be significantly associated with increased AMD risk (Yates et al., 2007). The association was confirmed by later studies (Fritsche et al., 2013). A three-cohort study of 3137 individuals revealed that the $C 2$ $C F B$ protective haplotype reduced the rate of AMD progression whereas the $C 3$ risk allele increased the rate of progression to advanced AMD (Francis et al., 2009).

A two marker haplotype upstream of the CFI $3^{\prime}$ UTR was associated with AMD in a study of 2053 individuals (Fagerness et al., 2009). Further investigation failed to identify possible coding variants, suggesting that this haplotype modulates gene regulation (Fagerness et al., 2009). Meta-analysis identified another SNP in the region (rs4698775) as associated with AMD (Fritsche et al., 2013), likely tagging the same haplotype. Hughes et al. identified a protective haplotype containing a 84,682 bp deletion spanning $C F H R 3$ and $C F H R I$ by genotyping chromosome 1q23 in 173 neovascular AMD patients and 170 age-matched controls (Hughes et al., 2006). The deletion was confirmed by multiplex ligation-dependent probe amplification. Western blot revealed loss of $C F H R I$ and $C F H R 3$ in deletion haplotype homozygotes (Hughes et al., 2006). Another study of three case-control cohorts demonstrated the deletion of $C F H R I$ and $C F H R 3$ is protective against AMD (Hageman et al., 2006). The finding was also supported by a $\mathrm{CNV}$ analysis interrogating the $C F H$ and CFHRI-5 locus (Kubista et al., 2011). However, the CFHR3-CFHRI deletion lacked strong signal in meta-analysis (Fritsche et al., 2013). An examination of 35 variants in 138 extremely discordant sibling pairs identified several variants associated with AMD, including variants in $C F H R 2$, 4, and 5 (Zhang et al., 2008). However, the authors acknowledged that these variants might be in LD with the nearby $C F H$ risk allele (H. Zhang et al., 2008). Targeted re-sequencing and exome-capture experiments have identified rare variants iny $C F H$ (R1210C (Seddon et al., 2014); R53C and D90G (Yu et al., 2014)), CFI (Seddon et al., 2013), C3 (K155Q (Seddon et al., 2013; Zhan et al., 2013)), and C9 (P167S (Seddon et al., 2014); R95* (Nishiguchi et al., 2012)). Overall, the association of variants in the genes that participate in the complement system and AMD is extremely compelling.

\section{Overview of choroidal structure and function}

In view of the activation of the complement system in the aging choroid (discussed below in Section 6), a brief discussion of the structure and function of this tissue follows.

\subsection{Structure of the choroid}

The inner neural retina possesses its own vascular network that enters the eye though the optic disc and that supplies and drains the inner retina. The outer retina, including the photoreceptor cells and RPE, is nourished by the choroid.

A detailed description of the anatomy of the choroidal circulation is provided elsewhere (Hayreh, 1975). In brief, the choroid is supplied by a series of posterior ciliary arteries branching from the ophthalmic artery outside of the globe and penetrating the sclera at multiple sites. These arteries supply terminal arterioles that supply individual, nonoverlapping choriocapillaris lobules. Blood leaving the choroid collects in a series of vortex veins that return the (partially deoxygenated) blood back to the systemic circulation. 
Its most distinctive anatomical feature is the choriocapillaris, a unique, lobular capillary bed that runs in a single plane beneath the RPE. The macular region of the choriocapillaris in particular shows a honeycomb like network when viewed en face (Fig. 4). The segmental pattern of vascular elements in the macula creates "watershed zones", in which the capillaries supplied by different posterior ciliary arteries have potentially non-overlapping areas of perfusion (Hayreh, 1990).

The choriocapillaris is a very dense vessel bed, which, in comparison to most tissues, has an extremely rich vascular supply-in normal eyes, the volume occupied by the vascular lumen in this layer is greater than the volume occupied by the intercapillary septa. Choriocapillaris endothelial cells are of the fenestrated type (discussed below), particularly at the inner surface (i.e., the surface facing the RPE) (Burns and Hartz, 1992; Mancini et al., 1986). The outer layers of the choroid have been traditionally referred to as Sattler's layer (consisting of intermediate sized vessels and the intervening connective tissue, adjacent to the choriocapillaris) and Haller's layer (consisting of larger vessels that give rise to and drain the arterioles and venules of Sattler's layer, respectively, between the Haller's layer and the sclera). In contrast to the choriocapillaris, these outer layers are less distinctive from each other, without obvious landmarks, and exist in a continuum of progressively larger vessels. The division of outer choroid into Sattler's and Haller's layers is nevertheless useful in specifying geographic position.

One explanation for the very high level of perfusion of the choroid is that it may be necessary due to the enormous utilization of oxygen by the retina, particularly in the dark. Elegant functional studies in living animals have been performed in which oxygen sensors have been employed to record the partial pressure of oxygen at different depths of the choroid and retina. Studies in rats (Lau and Linsenmeier, 2012), cats (Linsenmeier and Braun, 1992), and primates (Birol et al., 2007) have shown that the $\mathrm{PO}_{2}$ drops off precipitously from the RPE to the inner retina, with the most profound depletion of $\mathrm{O}_{2}$ within the mitochondria-rich photoreceptor cell inner segments. In fact, the partial pressure of oxygen in cat inner segments approaches zero (Linsenmeier, 1986). Thus an extremely dense choriocapillaris undoubtedly facilitates the retina's very high consumption of oxygen. In conditions of hyperoxia, the $\mathrm{O}_{2}$ penetration into the retina is deeper than in normoxia (Wangsa-Wirawan and Linsenmeier, 2003).

One puzzling feature of this relationship is that the $\mathrm{PO}_{2}$ entering the choroid through the short posterior ciliary arteries and the $\mathrm{PO}_{2}$ exiting the choroid through the vortex veins is essentially equivalent-in other words, although photoreceptors utilize an enormous amount of oxygen, the extraction of oxygen from the choriocapillaris is poor (Alm and Bill, 1972; Linsenmeier and Padnick-Silver, 2000). It appears that while a very large amount of oxygen is being used by the photoreceptor cells, with the highest oxygen metabolism per gram of any tissue in the body (Ames, 1992), this utilization of oxygen does not noticeably deplete choroidal $\mathrm{O}_{2}$. The notion that the choroid is "overengineered" for $\mathrm{O}_{2}$ delivery suggests other functions for the choriocapillaris, discussed further below. 


\subsection{Immune state of the choroid}

The choriocapillaris has an unusually active baseline immune state. Molecules that in other vessel beds are activated during inflammation are constitutively expressed by choriocapillaris endothelial cells; these include intercellular adhesion molecule-1 (ICAM-1) (McLeod et al., 1995) and MHC class I antigens (Abi-Hanna et al., 1988; Goverdhan et al., 2005).

ICAM-1 is a single pass, type I transmembrane protein with a primary role in recruiting circulating monocytes and neutrophils. It is also expressed in neural retina, within the external limiting membrane and in photoreceptor rosettes in end stage AMD (Mullins et al., 2006); in diabetic retinopathy, ICAM-1 is also expressed in retinal vessels (McLeod et al., 1995). Compared to the choroidal isoform, retinal ICAM-1 is of slightly lower molecular weight owing to its relatively low degree of N-glycosylation (Mullins et al., 2006). This adhesive glycoprotein has been of interest in AMD; for example, laser ablation of Bruch's membrane in I $\mathrm{cam}^{-1-}$ mice results in smaller neovascular membranes than observed in wild type mice, suggesting a necessary role for ICAM-1 in promoting pathologic angiogenesis in AMD (Sakurai et al., 2003). In humans, the macular choriocapillaris was found to have more abundant ICAM1 protein than the extramacular choriocapillaris, suggesting a mechanism for the macular predisposition of CNV (Mullins et al., 2006). In experiments using human organ cultures, the high levels of ICAM-1 in the choriocapillaris can be further elevated in response to inflammatory stimuli such as bacterial lipopolysaccharides (Zeng et al., 2012) and complement anaphylatoxins (Skeie et al., 2010), and de novo synthesis in response to some stimuli is mitigated by the presence of soluble components of the AREDS-1 vitamin formulation (Age-Related Eye Disease Study Research Group, 2001; Zeng et al., 2012).

Choriocapillaris endothelial cells also have high baseline expression of MHC class I antigen with little or no expression of MHC class II antigens. MHC class I proteins normally display self antigens to the adaptive immune system, including presentation of viral peptides in infected cells. In addition to their role in cell recognition, studies in mice indicate that high endothelial cell expression of MHC class I supports CD8+ T cell migration into an inflamed tissue (Lozanoska-Ochser and Peakman, 2009). A baseline level of expression of MHC antigens is necessary, and loss of MHC class I antigen expression results in induction of apoptosis by natural killer cells (Parham et al., 2012). The very high expression of self MHC antigens also has repercussions for the replacement of dead choriocapillaris endothelial cells (discussed in Future Directions below).

In addition to endothelial cells, the choroid possesses several other types of transient and resident cells. These include fibro-blasts, common in connective tissues, neural crest-derived melanocytes, pericytes and smooth muscle cells, and an array of hematopoietic cells that includes mast cells, resident macrophages/ dendritic cells, and lymphocytes. Moreover, the choroid contains neurons, both derived from nerve processes that run along the oculomotor and facial cranial nerves (Schrödl et al., 2006) and a class of ganglion cells that resides entirely in the choroid (May and Lütjen-Drecoll, 2005; May et al., 2004). The innervation of the choroid includes roles for neurons that terminate on large vessel walls and that deliver 
the potent vasodilator nitric oxide ( $\mathrm{Li}$ et al., 2010) as well as those without obvious innervation of vascular elements. The role of innervation in maintaining a healthy choroid is an important and active area of study (Fitzgerald et al., 2005; Jablonski et al., 2007; Li et al., 2010; Nickla and Wallman, 2010).

\section{Molecular changes in the choroid in AMD: C-reactive protein}

One molecular clue about the pathogenesis of AMD, and how genetic risk factors may influence the course of disease, is the finding of elevated C-reactive protein (CRP) in the blood and eyes of patients with AMD and with high-risk CFH genotypes, respectively.

C-reactive protein (CRP) is a $25 \mathrm{kDa}$ protein that is assembled into a pentamer. It is a member of the group of proteins called acute phase proteins, that includes serum amyloid A component, fibrinogen, ceruloplasmin, and numerous complement proteins (Gabay and Kushner, 1999). Acute phase proteins are made in liver and represent a systemic response to infection, in which the levels of these proteins spike in the plasma in response to generalized distress. Conditions resulting in elevated CRP include bacterial infections, cell or tissue damage, and other systemic inflammatory conditions. When hepatocytes are exposed to IL-6, IL-1 or IL-17, they increase expression of CRP, which is secreted as a homo-pentamer (Eklund, 2009). CRP has functions in binding certain classes of bacteria; it was originally identified as a constituent of the serum of severely ill (but not recovering) pneumonia patients, and was named after its ability to bind a preparation of pneumococcus termed "fraction C" (Tillett and Frances, 1930).

While CRP is elevated in blood in response to severe, systemic infectious diseases, the discovery that CRP is modestly (but significantly) elevated in patients with vascular diseases has been of enormous benefit in medicine. Although a discussion of CRP in systemic vascular disease is beyond the scope of this review, it is notable that individuals with stroke, coronary artery disease, and other cardiovascular diseases show significantly increased CRP levels (Rifai and Ridker, 2001; Taubes, 2002).

Seddon and colleagues addressed the question of elevated CRP and other circulating inflammatory molecules in relation to AMD progression rate and found a significant increase in serum CRP levels as the disease progressed in AMD patients. They concluded that low-, medium-, and high-risk AMD groups correspond to $\$ 0.5 \mathrm{mg} / \mathrm{L}, 0.5-10.0 \mathrm{mg} / \mathrm{L}$, and $\geq 10.0 \mathrm{mg} / \mathrm{L}$ serum CRP concentrations, respectively (Seddon et al., 2005, 2004), although this association has not been universally reported (McGwin et al., 2005). A more recent study by Seddon and others has shown that high levels of serum CRP are associated with a higher risk of AMD, regardless of Y402H CFH genotype (Seddon et al., 2010).

Johnson and colleagues sought to determine the localization and abundance of CRP and $\mathrm{CFH}$ in the extra-macular choroid of donor eyes homozygous for the high-risk $\mathrm{Y} 402 \mathrm{H}$ genotype and donor eyes homozygous for the low-risk 402Y genotype (Johnson et al., 2006). While the localization and abundance of $\mathrm{CFH}$ was not found to differ between $C F H$ genotypes, choroidal immuno-staining of CRP was significantly higher in the $402 \mathrm{HH}$ eyes compared to the 402YY eyes, and measurements of abundance confirmed a relative increase in the level of CRP in the at-risk choroids. Interestingly, the differences observed between 
the $C F H$ homozygotes were independent of AMD status. Since the high-risk allele affects binding of CFH to CRP, possibly due to the reduced binding efficiency of CRP to CFH 402H (Laine et al., 2007), lack of CFH binding could potentially increase the proinflammatory function of CRP in choroidal tissue, contributing to AMD pathogenesis.

Interestingly, $\mathrm{CFH}$ and $\mathrm{CRP}$ have distinct, and perhaps opposite, patterns of localization in the aging eye. Bhutto and colleagues examined the distribution of CRP and CFH in macular tissue from AMD donor eyes versus age-matched control eyes, and found an inverse relationship between CRP and CFH levels in eyes with advanced AMD (Bhutto et al., 2011). In AMD, Bruch's membrane, drusen, intercapillary pillars, and choroidal vessel walls all showed increased labeling of CRP-and decreased labeling of CFH-compared to agematched controls. In regions of geographic atrophy, both CRP and CFH levels were lower in Bruch's membrane and the choriocapillaris than in healthy controls, consistent with sparse perfusion in the former. The findings of increased CRP and decreased CFH in AMD support the idea that the maculas of AMD patients have an increased inflammatory microenvironment with decreased capacity for complement inhibition.

A number of functional studies have explored the interaction of CRP with cell types involved in AMD. In ARPE-19 cells, CRP significantly increases expression of the proinflammatory cytokine IL-8, via activation of several parallel signaling pathways (eg. NF$\mathrm{kB}$ pathway), in a dose-dependent manner (Wang et al., 2010b). In the same study, CRP exposure led to increased VEGF production by ARPE-19 cells, indicating a functional effect of CRP on RPE cells. It is not clear that CRP is a major effector on RPE cells in vivo, since the RPE is rarely labeled with antibodies directed against CRP in human donor eye sections; however, CRP immunoreactivity is occasionally reported with RPE cells located over drusen (Johnson et al., 2006). Vascular endothelial cells also respond to CRP by increased expression of a pro-inflammatory repertoire of adhesion molecules. Human umbilical vein endothelial cells show dose-dependent increases in E-selectin, ICAM-1 and VCAM-1 (Pasceri et al., 2000). Khreiss and colleagues reported similar findings in coronary artery endothelial cells and determined that dissociation of CRP from a homopentamer to its monomeric form was required for the activation of endothelial cells in vitro (Khreiss et al., 2004). Whether choroidal endothelial cells show similar molecular responses has not yet been determined.

Given the well-established role of complement genes in AMD (discussed in Section 2 above), it is of particular interest that CRP is capable of activating complement. While the circulating pentameric form of CRP (pCRP) has net anti-inflammatory effects (Filep, 2009; Schwedler et al., 2006), monomeric CRP (mCRP) is capable of binding C1q and subsequently activating complement via the classic pathway (Wang et al., 2011). One stimulus for the dissociation of pCRP to mCRP is membrane lipids on platelets or apoptotic cells (Eisenhardt et al., 2009).

\section{The complement system: overview}

The complement system is a major component of the innate immune system. It is evolutionarily ancient, dating from the Cambrian era- $C 3$ and other genes that participate in 
complement activation in humans have orthologs in members of invertebrate phyla such as Cnidarians and Echinoderms (Nonaka and Kimura, 2006; Pinto et al., 2007). These molecules play roles in facilitating phagocytosis by opsonization, ligand binding, proteolysis, and chemotaxis (Clow et al., 2004; Melillo et al., 2006). At some point in phylogeny, these proteins were co-opted by the adaptive immune system (Nonaka and Yoshizaki, 2004).

Components of the complement system include a large number of circulating, extracellular matrix, and membrane-bound proteins. The system can be divided into three pathways, based on its mode of activation. These pathways are distinguished by unique combinations of surveillance sensors, triggering events, and downstream effectors. However, each pathway merges back into a common trajectory, culminating in the formation of the membrane attack complex (MAC) and, potentially, cell lysis. The complement system serves as a specialized defense unit, poised to assist other forces once the enemy is engaged (classical pathway), to guard the body against stereotypical enemies (lectin pathway), and to attack in the absence of appropriate bodyguards (alternative pathway).

The classical pathway usually responds to antigen-antibody complexes. The molecular surveillance system in this pathway is the $\mathrm{C} 1$ complex, composed of one $\mathrm{C} 1 \mathrm{q}$ molecule and two molecules each of C1r and C1s (Degn et al., 2007; Wallis et al., 2010). The C1 complex becomes activated upon binding either IgM or IgG immune complexes. Activated $\mathrm{C} 1$ complex cleaves complement components $\mathrm{C} 2$ and $\mathrm{C} 4$, producing $\mathrm{C} 2 \mathrm{a}, \mathrm{C} 2 \mathrm{~b}, \mathrm{C} 4 \mathrm{a}$, and $\mathrm{C} 4 \mathrm{~b}$. $\mathrm{C} 4 \mathrm{~b}$ and $\mathrm{C} 2 \mathrm{a}$ bind to form $\mathrm{C} 4 \mathrm{~b} 2 \mathrm{a}, \mathrm{a} \mathrm{C} 3$ convertase. $\mathrm{C} 4 \mathrm{~b} 2 \mathrm{a}$ accelerates the already spontaneous hydrolysis of $\mathrm{C} 3$ into $\mathrm{C} 3 \mathrm{a}$ and $\mathrm{C} 3 \mathrm{~b}$. $\mathrm{C} 4 \mathrm{~b} 2 \mathrm{a}$ physically binds $\mathrm{C} 3 \mathrm{~b}$, becoming a $\mathrm{C} 5$ convertase. Cleavage of $\mathrm{C} 5$ produces $\mathrm{C} 5 \mathrm{a}$ and $\mathrm{C} 5 \mathrm{~b}$. C5b accumulatively binds $\mathrm{C} 6$ and C7, allowing for insertion into the hydrophobic cell membrane. C5b-7 then bind C8, creating a small pore complex (Zalman and Muller-Eberhard, 1990). The MAC is achieved after the binding of several $\mathrm{C} 9$ molecules, forming a formidable thoroughfare through the membrane, leading to sublytic injury or lysis and death of the cell (Takano et al., 2013).

The lectin pathway recognizes molecular patterns associated with bacterial cell walls, such as mannose residues, either via mannose-binding lectin (MBL) or ficolin (Wallis et al., 2010). Once activated, MBL or ficolin binds mannose-binding lectin serine peptidases (MASPs), a set of three proteins that cleave C2 and C4 (Sekine et al., 2013). Upon cleavage of $\mathrm{C} 2$ and $\mathrm{C} 4$, the lectin pathway merges with the classical pathway (Wallis et al., 2010).

Activation of the alternative pathway follows a different approach than either the classical or lectin pathway. Under normal physiological conditions, C3 spontaneously hydrolyzes to $\mathrm{C} 3 \mathrm{a}$ and $\mathrm{C} 3 \mathrm{~b}$ in a process termed tickover (Thurman and Holers, 2006). Binding of C3b to complement factor B forms a C3 convertase, creating a C3b amplification loop. However, the catalytic activity of $\mathrm{C} 3 \mathrm{bBb}$ is blocked by the negative regulators, complement factor $\mathrm{H}$ (CFH) and complement factor I (CFI) (Bexborn et al., 2008). CFH binds to host cell extracellular matrix molecules and recruits CFI (Langford-Smith et al., 2013). CFI then inactivates $\mathrm{C} 3 \mathrm{~b}$, preventing MAC formation on the host cell surface. However, in the absence of $\mathrm{CFH}$, the amplification loop rapidly increases local $\mathrm{C} 3 \mathrm{~b}$ concentration. A second 
$\mathrm{C} 3 \mathrm{~b}$ can bind to $\mathrm{C} 3 \mathrm{bBb}$ to form $\mathrm{C} 3 \mathrm{bBb} 3 \mathrm{~b}$, a $\mathrm{C} 5$ convertase, leading to MAC formation (Thurman and Holers, 2006).

In addition to MAC formation and cell lysis, the complement cascade performs other related functions. Binding of complement components to antigen bound IgM and IgG enables opsonization, the coating of foreign cells for disposal by professional phagocytes (Flyvbjerg, 2010). The breakdown products $\mathrm{C} 3 \mathrm{a}, \mathrm{C} 4 \mathrm{a}$, and $\mathrm{C} 5 \mathrm{a}$ act as anaphylatoxins, triggering extravasation and/or degranulation of host immune cells (Flyvbjerg, 2010). The complement system also mediates debris clearance and synapse pruning (Stevens et al., 2007).

Given the proximity of target and non-target cells, Brownian jostling at the site of complement activation can lead to bystander injury as MAC may be formed on nearby host cells. To minimize these events, the complement system is carefully regulated (Zipfel and Skerka, 2009). Complement decay accelerating factor (DAF), a GPI-anchored glycoprotein encoded by $C D 55$, resides at host cell surfaces and inhibits $\mathrm{C} 4$ and $C 3$. Another glycoprotein, CD59, hinders binding of $C 9$ in the C5b-8 complex. The $\mathrm{C} 1$-inhibitor SERPING1 disables C1r, C1s, MASP-1, and MASP-2. C4 binding protein inhibits C4 among other roles. Cellular clearance of complement opsonized immune complexes can occur through complement receptor 1 (CR1/CD35). Membrane-cofactor protein (MCP/ CD46) works as a cofactor for CFI, mentioned previously. In contrast to the negative regulators, properdin (complement factor $\mathrm{P}$ ) stabilizes the $\mathrm{C} 3 \mathrm{bBb}$ complex at the cell surface, interfering with the ability of CFH-CFI to inactivate C3b (Zipfel and Skerka, 2009).

Ultimately, regardless of the initial triggering pathway, un-checked complement activation results in the formation of the $\mathrm{MAC}$, in which a radial assembly of $C 9$ molecules penetrates the plasma membrane forming a pore. The compromise of the plasma membrane floods the cell with calcium, admixing cytosolic and extracellular compartments. While cells may tolerate a degree of cell surface perforation, sufficient numbers of uncleared MAC complexes cause cell lysis.

\section{The membrane attack complex in AMD}

In light of the compelling evidence of genetic variations in AMD that affect the complement system, a survey of the complement system's activity in human macula is essential. As a framework for the goal of understanding the impact of complement in AMD, and for addressing any complex issue, one may refer to Rudyard Kipling, who wrote in Just So Stories for Little Children,

"I Keep six honest serving-men

(They taught me all I knew);

Their names are What and Where and When

And How and Why and Who."

These questions are taught to aspiring journalists as the keys to properly understanding and relating a story. In the case of the complement system in AMD, below we attempt to address some of these questions as they pertain to the membrane attack complex.

Prog Retin Eye Res. Author manuscript; available in PMC 2016 March 01. 
Where are complement complexes distributed?

One of the most physiologically important findings of complement in aging human macula is that the MAC is distributed primarily at the level of the choriocapillaris. As described previously (Hageman et al., 2005; Seth et al., 2008; Skeie et al., 2010; Mullins et al., 2014) the abundance of the MAC increases with advancing age and, compared to age-matched controls, in donors with AMD. Moreover, eyes from donors with high-risk $C F H$ genotypes have significantly elevated levels of the MAC compared to individuals with low-risk genotypes (Mullins et al., 2011a).

It is important to note that the RPE may have a better arsenal of anti-complement defenses than the choriocapillaris. Several studies have found that CD46 was robustly expressed in the RPE, whereas there are inconsistent data regarding cell surface complement inhibitors on the choriocapillaris (Ebrahimi et al., 2013; Fett et al., 2012; Vogt et al., 2006). Interestingly, reduced expression of CD46 has been described on RPE cells in eyes with advancing geographic atrophy (Ebrahimi et al., 2013; Vogt et al., 2011), suggesting that only in advancing AMD does the RPE become susceptible to complement injury, consistent with findings of occasional MAC deposition on the RPE in advanced AMD (Mullins et al., in press). It is therefore likely that the choriocapillaris relies more heavily on $\mathrm{CFH}$ for protection against complement injury than other cell types in the posterior pole and may be more sensitive to CFH dysfunction.

When is complement deposited?

The MAC is abundant in older eyes and has been consistently reported in eyes over 50 years of age by immunohistochemistry (Hageman et al., 2005; Seth et al., 2008). Using sucrose cryoprotected sections and immunofluorescent detection, we recently described that the MAC is present surprisingly early and consistently in the human macula. By 21 years of age, the MAC is frequently observed in our hands, with choroidal labeling as early as 5 years of age (Mullins et al., in press). These findings suggest that-at some level-choriocapillaris endothelial cells are exposed to MAC for decades before the development of significant drusen, RPE changes or choroidal vascular dropout. More quantitative ELISA studies, however, show a striking increase in aging with additional increases in AMD (Mullins et al., 2014). Thus, while MAC is formed at the choriocapillaris throughout life, its contribution to stress of choroidal EC dramatically increases in aging (Fig. 5).

Why is MAC distributed in aging choriocapillaris?

The striking accumulation of the MAC in the aging macula is surprising. Complement activation as a response to injury is well appreciate-dand usually occurs in response to acute injury, such as stroke (Ducruet et al., 2009). That MAC is present without any obvious damage might suggest that it plays a "housekeeping" role, or at least that at low levels it is not pathogenic. Activation of the MAC has been suggested as beneficial in some diseases of the central nervous system (Rus et al., 2006) raising the question as to whether some level of MAC be helpful in the normal macula.

Prog Retin Eye Res. Author manuscript; available in PMC 2016 March 01. 
One can speculate that a role for the MAC in the human macula is that it serves to opsonize debris from the enormous removal and degradation operation performed daily by the RPE. Each day, the RPE phagocytoses and completely digests approximately the outer $10 \%$ of the outer segment layer of the photoreceptor cells. Assuming that the average outer segment is a cylinder $1 \mu \mathrm{m}$ in diameter and $30 \mu \mathrm{m}$ in length (Forooghian et al., 2010) (assumptions which are increasingly or decreasingly accurate depending on one's position in the fundus), then the average volume of an outer segment is approximately $24 \mu \mathrm{m}^{3}$ and $10 \%$ of this value is $2.4 \mu^{3}$. With approximately 100 million photoreceptors, the volume of $240,000,000 \mu^{3}$ $(0.24 \mathrm{cc})$ needs to be completely turned over each day by a workforce of about 5 million RPE cells. The load for each RPE cell is, on average, roughly $48 \mu \mathrm{m}^{3}$ per day. During normal aging, RPE cells are lost at a rate of about $2 \%$ per decade, meaning that this load may increase with aging. Macular loss in older eyes is predicted to be higher, although cells lost in the macula are potentially replaced by migration from peripheral regions (Del Priore et al., 2002). Interestingly, rod loss and RPE loss are not well correlated (Ach et al., 2014).

While cone photoreceptor outer segments turnover less than rods, and AMD is a macular disease, this is small help to lightening the load of the RPE, since the central retina-while cone enriched-still has many millions of rods (Curcio et al., 1990).

Thus, one can envision a potentially beneficial role for MAC formation between the RPE and choroid, particularly if the degradation of outer segments by the RPE becomes slightly less perfect during aging. If the MAC is beneficial in removal of outer segment debris, then patients with genetic inability to activate MAC might be expected to show increased debris in Bruch's membrane or, perhaps, elongated outer segments as we described in Best disease (Kay et al., 2012). Experiments in this area will provide useful insights.

While it is feasible that complement activation is beneficial in turning over excess debris from the retina, the MAC increases strikingly in aging and in AMD, which we propose likely overwhelms the potential benefits.

Another consideration for why the MAC forms where it does may relate to other distinctive aspects of the biochemistry of the neural retina and the RPE. Certain classes of long chain and very long chain fatty acids are enriched in photoreceptor outer segments (Liu et al., 2010, 2013). These fatty acids, which show very limited distribution elsewhere in the body, can be converted into a distinct array of metabolites by the RPE following phagocytosis. These include both neuroprotective molecules like NPD1 (Gordon and Bazan, 2013), as well as potentially pro-inflammatory molecules like carboxy-ethyl pyrrole (CEP).

Posttranslational modification of proteins and lipids by CEP has been of particular interest to the field, based on studies by Hollyfield, Salomon, Crabb, and colleagues showing: 1) CEPmodified macromolecules at the RPE-choriocapillaris interface in AMD; 2) autoantibodies in human AMD patients with anti-CEP activity (Gu et al., 2003); 3) biological activities of CEP modified proteins that are pro-angiogenic (Ebrahem et al., 2006); and 4) recapitulation of aspects of AMD in mice immunized with CEP adducts (Hollyfield et al., 2008). These studies, taken together, suggest that a possible explanation for the choroidal deposition of MAC is due to the unique microenvironment of the aging Bruch's membrane/ choriocapillaris complex. 
How is complement activated in aging choroid?

The mechanism of complement activation in AMD is not currently understood. It has long been appreciated that the initiating stages of complement activation can occur by multiple independent pathways that all converge at the cleavage of C3 (Fig. 6). Importantly, single nucleotide polymorphisms in multiple members of the alternative and terminal complement system have been reproducibly reported as statistically elevated in AMD subjects (described above in Section 2).

The mechanism of complement activation in the choriocapillaris could in principle be any of the several activation pathways, including the classical, lectin, or alternative pathways.

Based on the compelling genetic data, as well as studies showing that the alternative complement pathway contributes to experimental choroidal neovascularization in mice (e.g., (Rohrer et al., 2012)) one may reasonably invoke the alternative pathway as the most important in AMD. Whether CRP activation of complement using the classical pathway is operative in the human macula is an area of current study.

What is the consequence of increased MAC and anaphylatoxin generation in AMD eyes?

A possible consequence of prolonged exposure of the choriocapillaris to the MAC is that bystander lysis to endothelial cells may occur. The evidence for vascular dropout in the earliest stages of AMD is addressed below. In addition, MAC activation generates small Nterminal fragments of $\mathrm{C} 3$ and $\mathrm{C} 5$ (C3a and $\mathrm{C} 5 \mathrm{a}$ ) that have inflammatory effects in the posterior pole. Receptors for $\mathrm{C} 5 \mathrm{a}$ are expressed in the choriocapillaris and treatment of human organ cultures with C5a results in increased ICAM1 expression (Skeie et al., 2010). The genetic ablation of the $\mathrm{C} 3 \mathrm{a}$ and $\mathrm{C} 5 \mathrm{a}$ receptors in mice is protective against experimental choroidal neovascularization (Nozaki et al., 2006). Stimulation of T-cells with C5a increases production of IL-17 (Liu et al., 2011), a molecule that is cytotoxic to the RPE and is implicated in AMD (Ardeljan et al., 2014). Thus, direct cytolysis of the choriocapillaris endothelium as well as a pro-inflammatory shift in the extracellular microenviroment are both potential outcomes of MAC formation that are harmful to the choroid, RPE, and photoreceptor cells.

\section{Choroidal vascular loss in early AMD}

As discussed in the previous section, MAC is deposited in the aging choriocapillaris with higher levels in eyes with AMD. In this context, understanding the extent to which choriocapillaris undergoes degeneration in early and advanced AMD is necessary.

\subsection{Histological studies}

Ramrattan et al., in a large morphometric study using paraffin embedded, hematoxylin-eosin stained sections of human maculas, quantified elements of the choroid in a series of 95 eyes with and without AMD (Ramrattan et al., 1994). These authors found that the length of intact choriocapillaris per length of Bruch's membrane over which choriocapillaris measurements were collected significantly decreased in AMD, consistent with choriocapillaris dropout. While this capillary loss was most striking in eyes with geographic 
atrophy and disciform scarring, 9 eyes in the study with basal laminar deposits (i.e., early dry AMD) also showed significantly decreased choriocapillaris density. Further, choriocapillaris ghost vessels have been associated with basal linear deposit and sub-retinal drusenoid deposit (Curcio et al., 2013). In contrast, Spraul and colleagues used similar methods to study 80 donor eyes (19 of which had atrophic AMD) and detected an increased vascular density in the eyes with AMD, although large vessel density was found to be lower in AMD (Spraul et al., 1996). One possible reason for the discrepancies between different reports relying on hematoxylin-eosin stained sections is that choriocapillaris ghost vessels (discussed below) may not be readily distinguished from healthy vessels in the absence of markers of viable endothelium or sufficient resolution to thoroughly assess the quality of the vasculature. Acellular choroidal capillaries or ghost vessels were generally not discussed in these reports. Thus, even a very well powered study that lacks sufficient ability to distinguish an empty from a lined capillary lumen will not provide sufficient information about the state of the choroid.

One solution to this limitation is the use of transmission electron microscopy, to provide sufficient resolution to unambiguously identify vascular loss. In a large histopathologic series, Sarks performed light and electron microscopic analysis and noted hyalinization and expansion of the extracellular matrix of intercapillary pillars with accompanying loss of choriocapillaris (Sarks, 1976). She further noted that as AMD advances, "the space previously occupied by the capillary" becomes "filled with collagen and various cells," with a significant decrease in the area of viable capillaries beneath Bruch's membrane prior to gross atrophy (Sarks, 1978). Biesemeier et al. performed quantitative histology on a series of 35 eyes (12 atrophic or neovascular AMD and 23 controls). These authors noted that there was substantial loss $(27 \%)$ of the choriocapillaris in areas with intact RPE in AMD compared to controls. The selective loss of the choriocapillaris, compared to the RPE, was most notable in dry, early AMD (Biesemeier et al., 2014).

An alternative approach to transmission electron microscopy is the use of molecular markers that can identify endothelial cells based on their profile of expressed epitopes. Markers of viable EC include proteins like CD31/PECAM1 and CD34 (Lutty et al., 2010), as well as endogenous alkaline phosphatase activity. The endogenous alkaline phosphatase activity of human choroid has been used to great effect to characterize the choroidal vasculature in health and disease in whole mount approaches developed by the Lutty laboratory (Lutty and McLeod, 2005; McLeod et al., 2009; McLeod and Lutty, 1994). Our laboratory has largely employed the fucose-binding lectin, Ulex europaeus agglutinin-I (UEA-I), to assess the human choroidal vasculature using epi-fluorescence microscopy (Mullins et al., 2011b). Each of these markers has some limitations. We found that a subset of capillary endothelial cells loses CD34 expression and that this phenotype change occurs as a function of age. Moreover, the same cells that lose CD34 expression retain both UEA-I-binding glycoconjugates and alkaline phosphatase activity, indicating that morphometric studies relying on CD34 expression to mark viable endothelium may underrepresent the actual number of cells (Sohn et al., 2014a). Alkaline phosphatase activity and UEA-I affinity are species specific, and neither of these markers robustly identifies choroidal endothelium in 
non-human primates (Otsuji et al., 2002), so these approaches in humans are not generalizable to other species.

Using a modified version of their alkaline phosphatase method, the Lutty group performed partial bleaching of melanin to allow simultaneous quantification of RPE pigment and alkaline phosphatase reaction product. These investigators provided evidence for loss of choriocapillaris endothelial cells beneath an intact RPE monolayer in 3 donors with choroidal neovascularization, whereas 5 donors with geographic atrophy showed predominant RPE loss (with a very narrowed, but viable, choriocapillaris). These results suggest that different end-stages of AMD exhibit different rates of loss of RPE and choriocapillaris. The finding that the endothelium dies adjacent to CNV may seem paradoxical, since in a simplistic situation, overgrowth of the choroid would be expected in $\mathrm{CNV}$. However, acute injury of choroidal endothelial cells results in increased expression of pro-angiogenic genes, linking acute injury with angiogenesis (unpublished data).

We have sought to understand the relationship between RPE and choriocapillaris health in eyes with early AMD. To address this question we performed morphometric experiments on the choroidal vasculature and drusen in a series of 45 human donor maculae from 45 donors. Eyes were selected to include early AMD $(n=21)$ and age-matched controls $(n=24)$. Masked samples were sectioned and labeled with UEA-I lectin and anti-CD45 antibody. Cross sectional areas of choriocapillaris lumens, number of ghost vessels per unit length, and combined subRPE drusen and basal deposits (not readily distinguished on frozen sections) were quantified. After unmasking the collected data, we determined that there is a statistically significant, inverse relationship between the cross sectional area of deposits and the vascular density of the choriocapillaris. Somewhat surprisingly, measurement of RPE height in the same samples showed no significant difference in RPE as drusen volume increased (Fig. 7).

One question raised by the observation that lower capillary density is related to higher drusen density is whether the lower vascular density is due to loss of capillaries or a congenitally less robust choriocapillaris in eyes that will later develop drusen. To address this, we also quantified ghost vessels in the same donor set. Ghost vessels were defined as UEA-I negative, hypofluorescent cavities between two intercapillary pillars (Fig. 8). A direct relationship was found between drusen and choriocapillaris ghost vessels. Because ghost vessels indicate formerly occupied capillaries, we suggested that this relationship is most likely due to capillary loss, rather than a congenitally lower vascular density in individuals prone to develop drusen.

\subsection{Gene expression}

Vascular dropout as a feature of early AMD is also seen in molecular studies of affected and control human donor eyes. To investigate the effects of early AMD on gene expression in human RPE/choroid, we compared gene expression between nine early AMD eyes, exhibiting macular drusen and/or RPE changes, and seven control eyes with a recent ophthalmological exam negative for AMD, using Affymetrix Human Exon ST 1.0 arrays (Whitmore et al., 2013). To disentangle the relative changes within RPE and choriocapillaris, we performed Gene Set Enrichment Analysis (GSEA) using pre-defined 
RPE-specific and endothelium-associated gene sets, assuming that the cross-tissue contribution to either set would be negligible. The endothelium-associated gene set manifested lower expression in the early AMD samples as compared to controls (GSEA qvalue $<0.1$ ) with a slight increase in RPE-specific gene expression. This finding is consistent with morphologic findings of loss of endothelial cells in early AMD. We restratified the data based on $C F H$ Y204H risk genotype (11 high-risk, YH/HH samples; five low-risk, YY samples) and found thirty-five genes to be modestly differentially expressed between cases and controls (raw $p$ value $<0.01$ and at least \pm 1.5 fold change) though none were significant after false discovery rate correction. Nevertheless, several genes, such as $D C N$ (fold change AMD vs. control 2.19), TIMPI (fold change AMD vs. control -2.03), and ADAMTS9 (fold change AMD vs. control -2.61), suggest potential functional links between $C F H$ genotype and matrix remodeling and angiogenesis (Whitmore et al., 2013).

\subsection{Proteomics}

Interestingly, these histological and molecular findings are also consistent with proteomic studies from the Crabb laboratory, using different samples and different techniques. In a well-powered study, Yuan et al. isolated Bruch's membrane/choroid from a large number of human maculas assigned as either controls $(n=25)$ or different AMD classes $(n=24)$. The authors found that AMD maculas showed decreased abundance of proteins such as carbonic anhydrase 4, VWF, HLA-A and Plasmalemmal Vesicle Associated Protein-1 (Yuan et al., 2010)-all proteins that are highly enriched in the choroid (Hageman et al., 1991; Goverdhan et al., 2005). These authors also found a slightly increased level of RPE65 in their AMD samples (Yuan et al., 2010), presumably attributable to remaining RPE debris or RPEderived material in Bruch's membrane.

\subsection{Clinical studies}

Finally, in vivo assessment of blood flow in AMD has also been performed and is supportive of early loss of choriocapillaris in AMD. Pauleikhoff and colleagues measured choroidal filling using fluorescein and indocyanine green angiography in eyes with early AMD, and found slower kinetics of choroidal perfusion (a prolonged choroidal filling phase), consistent with vascular loss in these eyes (Pauleikhoff et al., 1999), an observation also made by Hayreh on fluorescein angiography (Hayreh, 1990). The Grunwald lab, using laser Doppler flowmetry, has quantified the movement of blood through the subfoveal choroid in eyes with early and advanced AMD and demonstrated significantly reduced blood volume and blood flow in association with extent of drusen, using linear regression (Berenberg et al., 2012). Elegant novel OCT approaches are now allowing the in vivo dissection of different layers of choroid (Zhang et al., 2012a). Although not yet widely studied, in one case when applied to a patient with geographic atrophy, choriocapillaris dropout was observed more diffusely than the area of RPE loss (Kim et al., 2013). Studies on additional patients will be needed to determine if this is a generalizable feature of geographic atrophy. Thus, in addition to histological observations, quantitative measurements of blood flow and microvascular structure in living AMD patients supports the notion that vascular changes occur in AMD prior to end stage disease.

Drusen are spatially associated with non-perfused choroid. 
At least as early as Friedman et al. (1963), some investigators have concluded that drusen do not form in a random fashion, but instead are distributed in association with underlying vascular structures. In his initial report, Friedman observed on whole mounted choroids that drusen were more frequently associated with Bruch's membrane overlying collecting venules. Sarks made a similar observation on the nonrandom distribution of drusen with the choroid; in ultrastructural preparations of AMD eyes, she noted that the smallest drusen often form over intercapillary pillars that contain debris, with root-like extensions into the choroid which she referred to as "entrapment sites" (Sarks et al., 1999). These studies were extended by Lengyel et al., who quantified the subset of drusen that autofluoresce in whole mounts and observed that these drusen show a preferential accumulation over intercapillary pillars (Lengyel et al., 2004). In morphometric studies, we found that the vascular density beneath drusen is approximately one half of the density between drusen (Mullins et al., 2011b).

Moreover, these spatial findings appear to be related to ghost vessels as well, although this is has been more difficult to establish statistically. As discussed above, maculas with more ghost vessels had significantly more subRPE deposits than eyes with fewer ghost vessels (Mullins et al., 2011b). We have further frequently observed that small drusen are often localized to regions of Bruch's membrane directly overlying ghost vessels (Fig. 9).

A final area of choroidal change in AMD that is becoming more widely appreciated is the change in choroidal thickness observed in different pathologic states. While previous studies of choroidal filling were possible using indocyanine green angiography (Slakter et al., 1995; Staurenghi and Flower, 2002), and while ICG continues to offer unique and valuable insights (e.g., (Giani et al., 2012)), the interpretation of the resulting data is often difficult. With the development of enhanced depth imaging OCT, it is now relatively straightforward to collect quantitative measures of choroidal thickness in living patients non-invasively (Spaide et al., 2008).

Choroidal thinning has been observed in human patients in normal aging and in eyes with AMD-in one study, choroids with early AMD were found to be more than $20 \%$ thinner than in age-matched control eyes, whereas fellow eyes in patients with polypoidal choroidal vasculopathy had choroids that were $69 \%$ thicker than the unaffected contralateral eye (Chung et al., 2011). Changes in choroidal thickness have been described in other pathologic conditions, and is remarkable in myopia (see for example, (Nickla and Wallman, 2010)) and central serous chorioretinopathy (Jirarattanasopa et al., 2012). In addition, Spaide recently described a clinical entity characterized by severe choroidal thinning, referred to as "agerelated choroidal atrophy" (Spaide, 2009).

Moreover, the study of human donors eyes and living patients indicates that the subfoveal choroid in geographic atrophy is significantly thinner than in control donor eyes. Whether this choroidal atrophy precedes or results from RPE degeneration in GA is not well understood. However, our donor eye studies suggest that eyes with geographic atrophy have choroidal thinning even in areas remote from the central GA (Fig. 10), so if RPE injury is primary the RPE exerts its effects millimeters from its site of degeneration. 
Choroidal thickness is susceptible to diurnal variations and environmental changes (e.g., related to water intake (Arora et al., 2012)), and these changes are on the order of a few micrometers to $30 \mu \mathrm{m}$, whereas the differences in some disease states may vary by well over $100 \mu \mathrm{m}$. Thus, the profound choroidal atrophy observed in many AMD patients with GA is most likely due to innate differences in the vascular, cellular and/or extracellular matrix elements of the choroid. What accounts for these differences is poorly understood.

We sought to determine whether eyes with high-risk genotypes in the $\mathrm{CFH}$ gene ( $\mathrm{Y} 402 \mathrm{H}$ allele, discussed above) have altered vascularity of the choroid. Specifically, choroidal thickness was quantified in 100 donor eyes. These experiments revealed that maculas from patients homozygous for the high-risk $\mathrm{Y} 402 \mathrm{H}$ genotype in the $C F H$ gene had significantly thinner choroids than those with low-risk genotypes (Mullins et al., in press). While the cellular and molecular basis of choroidal thinning is not completely understood, and events in the choriocapillaris may not be well reflected in the overall choroidal thickness, this study suggest a potential role for complement activation in atrophy of the choroid.

\section{Possible consequences of vascular loss in AMD}

\subsection{Hypoxia}

The most obvious consequence of depleting a major vascular supply is that the supported tissue may become hypoxic, with the well-characterized array of molecular and cellular responses (Stitt et al., 2011). Several of these processes, such as increased ICAM1 and a role for VEGF upregulation (Ablonczy et al., 2014) have been proposed in AMD. Hypoxia is an attractive pathway for AMD pathogenesis. It is consistent with the observed vascular loss in early AMD and is a stimulus that promotes angiogenesis, a critical process in end stage, neovascular AMD.

As discussed above, elegant experiments by Linsenmeier have shown that the neural retina consumes a very large amount of oxygen. A small decrease in perfusion might therefore be expected to be quite harmful to the photoreceptor cells, as suggested in the case of retinal detachment (Wang and Linsenmeier, 2007). Somewhat perplexing in this context is the observations that patients with Best disease can exhibit a subfoveal vitelliform lesion that is several times the thickness of the outer nuclear layer and yet retain good (20/25) cone vision for decades (Kay et al., 2012). It is possible that partial protection from hypoxia is offered by the modestly lower oxygen consumption reported in foveal (compared to perifoveal) primate photoreceptor cells (Birol et al., 2007). Moreover, in early AMD, rod loss is more notable than cone loss (Curcio, 2001) and rods appear to be more susceptible to mild ischemia than cones (Brunette et al., 1986), which may be consistent with the dark adaptometry findings in early AMD discussed above.

To date, gene expression studies of AMD eyes have not reported finding altered hypoxia pathways (Newman et al., 2012; Whitmore et al., 2013). It is possible that, due to the "overengineering" of the choroid described above, the retina does not experience major hypoxia with significant choriocapillaris dropout. In any case, further study is required to determine whether hypoxia is a major factor in the pathogenesis of early AMD.

Prog Retin Eye Res. Author manuscript; available in PMC 2016 March 01. 


\subsection{Impaired thermoregulation}

One interesting role for the choroid that has been suggested is that its large amount of flow participates in thermal regulation of the RPE and retina (Parver, 1991). The microvasculature in other tissues, especially the dermis of the skin, have well appreciated functions in thermoregulation, in which dilation leads to shedding of excess heat through the skin and vasoconstriction conserves heat. The choriocapillaris itself rather resembles a radiator or a cooling coil, particularly in the macular region (Fig. 4). The very high degree of metabolic activity by both the photoreceptor cells and the RPE is expected to have considerable heat as a byproduct. Moreover, although the absorption of stray photonspreventing light scattering and phototransduction in off target photoreceptor cells-is one of many critical functions of the RPE, this absorption of energy undoubtedly raises the temperature of the posterior pole.

Interestingly, raising the temperature of RPE cells in vitro leads to increased synthesis of a number of extracellular matrix molecules, including thrombospondin and tropoelastin (Sekiyama et al., 2012). The possibility that increased heat increases expression of extracellular matrix proteins in vivo might explain the formation of matrix-rich, basal laminar deposits, which are increased in aging and AMD (Sarks et al., 2007) and further increased in eyes with choriocapillaris dropout. Thus, altered temperature regulation, due to loss of choriocapillaris, could contribute to increased Bruch's membrane thickening and basal laminar deposits in AMD (Fig. 11). In addition, since mitochondrial function is highly dependent on temperature (Brooks et al., 1971), a small difference in temperature in the posterior pole could exacerbate phenotypes of AMD attributable to altered mitochondrial function.

Formally showing a role for the choroid in thermoregulation has been challenging. Temporarily clamping the choroidal (and retinal) circulation is possible using a device like an ophthalmodynamometer to raise the intraocular pressure above the blood pressure. In seminal studies in primates, Parver and colleagues raised the intraocular pressure in nonhuman primates by elevating the height of a fluid reservoir and measured temperature in the retina during intense light exposure. In the maculas of animals exposed to a bright light source, the retinal temperature increased as a function of intraocular pressure over the course of $\geq 1$ min (Parver et al., 1980). This change of slightly over one degree Celsius, while subtle, does suggest the choroid can cool the retina. Whether longer term loss of choroidal flow would be sufficient to raise the temperature to similar levels as those observed by Sekiyama et al. remains to be determined.

\subsection{Impaired clearance of Bruch's membrane debris}

One hypothesis for the relationship between drusen and vascular loss is that there is a loss of endothelial cell uptake in early AMD. Endothelial cells are not generally considered to be major phagocytic cells, and debris in Bruch's membrane may be predominantly removed by professional phagocytes (Forrester, 2003; Skeie and Mullins, 2009). Endothelial cells may remove material by endocytosis (using machinery that includes both fluid phase and receptor mediated mechanisms) to deliver material to the lysosomes, or by transcytosis, in which material is transferred across the endothelial cell using caveolae or other organelles. 
Endothelial cells are rarely observed removing material that requires formation of a phagosome. However, debris smaller than an organelle may be regularly cleared by a healthy choriocapillaris. Monkey (Tserentsoodol et al., 2006) and human (Fig. 12) choriocapillaris EC express low density lipoprotein receptor, and may therefore be involved in uptake of LDL. Overlay experiments, in which fluores-cent LDL is supplied to sections or organ cultures, shows that while the majority of LDL binding activity is present in choroidal macrophages, choriocapillaris also binds LDL. Whether the uptake of LDL in vivo is from the lumen to Bruch's membrane, from Bruch's membrane to the lumen, or bidirectional, is not well appreciated. Experiments in rats and primates show that LDL is trafficked from the vasculature through the choroid and into the RPE and photo-receptor cells (Tserentsoodol et al., 2006). On the other hand, we have found that human organ cultures, presented with fluorescent LDL on the abluminal surface, bind LDL (Fig. 12). If choroidal EC move lipid cargoes from Bruch's membrane into the blood, then clearly loss of choriocapillary EC by MAC injury or any other mechanism could promote the build up of lipid in Bruch's membrane.

The idea that endothelial cells can mobilize lipids from a high concentration in a tissue (such as Bruch's membrane) to a lower concentration (in the blood) should not be considered highly unusual. In adipose tissue, under conditions of low insulin, lipases hydrolyze triglycerides to glycerol and free fatty acids, the latter of which are then delivered to the vascular lumen by resident endothelial cells (Thompson et al., 2010). While the details of the molecular mechanism(s) of abluminal to luminal transport of lipids has not been thoroughly investigated, it is interesting that endothelial cells in obese mice show a loss of fenestrations in obese, compared to lean, mice (Cao et al., 2001); this ultrastructural finding is particularly interesting in light of the loss of choriocapillaris fenestrae in human eyes adjacent to GA (McLeod et al., 2009) and in otherwise non-specified AMD (Biesemeier et al., 2014). It is possible that the choriocapillaris assists in clearing lipids from Bruch's membrane using a similar mechanism to the loading of capillaries in adipose tissue. This is an area for future investigation.

There is additionally structural evidence that choriocapillary EC regulate Bruch's membrane composition by elaborating podosome-like organelles into Bruch's membrane. Such structures have been exquisitely demonstrated by Guymer and colleagues in hamster choroid using freeze fracture and conventional transmission electron microscopy and have also been shown in human donor eyes (Guymer et al., 2004) (see also Fig. 13). Extracellular, actin rich projections called podosomes or invadosomes in other tissues sequester matrix metalloproteinases and are required for normal ocular development and function (Mao et al., 2009).

The notion that healthy choriocapillaris serves as an active site of removal of debris is further buttressed by the studies of where drusen form topographically in aging eyes. As discussed above, studies by Lengyel et al. (2004), Sarks et al. (1999) and Mullins et al. (2011b) show increased drusen formation in association with areas without flow. Moreover, findings that drusen density increases as a function of density of ghost vessels support the notion that it is vascular non-perfusion, not the structure of the intercapillary pillar itself, that promotes the localized formation of drusen.

Prog Retin Eye Res. Author manuscript; available in PMC 2016 March 01. 
Clearance of material released by the RPE is especially important in the aging macula.

Curcio and colleagues have provided a detailed characterization of the "oil spill in Bruch's membrane", i.e., the age-related accumulation of lipoprotein-like particles and lipids in the inner layers of Bruch's membrane (reviewed in (Curcio et al., 2010, 2009, 2011)).

Transmission electron microscopy and the quick-freeze/deep-etch method were used to examine the ultrastructure of macular Bruch's membrane in four donor eyes from young (27, 41 yo) and older (76, 78 yo) donors (Ruberti et al., 2003). Lipid-rich particles were present in older donors in the lipid wall region between the elastic layer and inner collagen layer of Bruch's membrane. These particles exhibited an exterior shell and solid interior and were on average $80 \mathrm{~nm}$ in diameter, larger than the weave of collagen fibers in the basal lamina of the RPE (Ruberti et al., 2003). To determine possible sources of membranous debris observed in Bruch's membrane, these authors used osmiumtannic acidparaphenylenediamine and transmission electron microscopy to interrogate basal deposits and drusen in 20 donor eyes with preserved extracellular lipid (Curcio et al., 2005). Membranous debris found in basal laminar deposits ranged from 80 to $200 \mathrm{~nm}$ in diameter and was arranged in linear tracks or aggregations. In basal linear deposits and drusen, pathognomonic signs of AMD, lipids appeared in solid particles or neutral lipid pools (Curcio et al., 2005). Additional studies of sixteen human maculas revealed that lipoproteinlike particles, small granules, and membrane-like structures form the basic structural motifs of more complex lipid inclusions (Huang et al., 2007). The particles themselves remain relatively constant in size across age (Huang et al., 2008). Lipoprotein-like particles in human donor Bruch's membrane-choroids are high in esterified cholesteryl, contain retinol equivalents, but are compositionally more like low density lipo-proteins of plasma than that of photoreceptors (Wang et al., 2009b).

RT-PCR, Western blotting, and immunohistochemical studies suggest that RPE expresses many of the components necessary for lipoprotein processing and secretion. These enzymes include microsomal triglyceride transfer protein (required for lipoprotein assembly), the unedited isoform of apolipoprotein B (apoB-100), sterol o-acyltransferase 1 (ACAT-1, implicated in fatty acid ester formation) (Li et al., 2005b), lecithin cholesterolacyltransferase (LCAT), and its cofactor apoA-I (Li et al., 2005a). The composition and morphology of lipoprotein-like particles in Bruch's membrane are distinct from plasma lipoproteins, further supporting RPE production (Li et al., 2005a).

Given the distinct composition of lipoprotein-like particles in Bruch's membrane, their agerelated accumulation, and their likely production in the RPE, Curcio and colleagues have proposed that the pathogenesis of age-related maculopathy parallels the response-toretention model of atherosclerosis: the accumulation of lipids in Bruch's membrane inhibits transport to and from the RPE while lipid oxidation creates a pro-inflammatory environment, eventually leading to the recruitment of professional phagocytes and neovascularization (Curcio et al., 2011).

Indeed, the release of material into a surrogate Bruch's membrane (although with no flow beneath it) has been observed in vitro and proposed as a model of drusen formation (Johnson et al., 2011). The accumulation of this material over an extended period of time congeals into the lipid wall discussed above. Moreover, basal linear deposits, a defining histological 
finding in AMD (Curcio and Millican, 1999; Sarks, 1976), is comprised of vesicular lipid pro-files (Curcio and Millican, 1999). Functionally, this material contributes to loss of hydraulic conductivity across the Bruch's membrane/choroid (Starita et al., 1996). While this material is most likely expelled by the RPE, impaired uptake of lipoproteins from the injured or dedifferentiated choriocapillaris may contribute to its accumulation (discussed above).

\section{Choriocapillaris phenotype change in aging and AMD}

While there are unifying features of EC everywhere in the body (such as tube formation), EC show considerable anatomical, molecular and functional heterogeneity, both between tissues and within a tissue in different states. These differences may be significant in the pathogenesis of AMD and are briefly discussed below.

Structurally, it has long been appreciated that endothelial cells in the central nervous system (e.g., brain and retina), which comprise an element of the blood brain/blood retinal barrier, are the "continuous" type in which neurons are protected from circulating factors and specific uptake by the endothelium is required. In contrast, liver endothelial cells are sinusoidal, with discontinuous basal lamina and large (micrometer-sized) spaces between adjacent endothelial cells, allowing hepatocytes to seamlessly release newly synthesized plasma proteins into the systemic circulation. Fenestrated capillaries, such as those seen in renal glomerulus, are transitional between sinusoidal and continuous capillaries, with thin walls and diaphragmed openings on the order of 60-80 nm (Stan et al., 2012), depending on method of quantification and topographic region (Sugita et al., 1982). The two vascular beds of the posterior pole are comprised of capillaries of the continuous (retina) and fenestrated (choroid) type. In healthy eyes, retinal EC invariably have associated pericytes and astrocytes that help comprise the inner blood retinal barrier (Hosoya and Tomi, 2005), whereas pericytes in the choriocapillaris are much less abundant (Tilton et al., 1985) (Fig. 14). These structural distinctions between retinal and choroidal endothelial cells are born out by mRNA expression studies (Browning et al., 2012), proteomics (Zamora et al., 2007) and functional experiments as well (Stewart et al., 2011).

Even within a vascular bed, there is heterogeneity of the endothelium. This is notable in choroid, in which the glycosphingolipid anchored enzyme, carbonic anhydrase IV, is localized to the choriocapillaris but is absent in the EC of intermediate and large caliber vessels (Hageman et al., 1991). In addition, MHC class I antigens, highly expressed in choroidal EC, are more abundantly expressed in choriocapillaris EC compared to large choroidal EC, whereas von Willebrand factor is more highly expressed in large vessels (Goverdhan et al., 2005).

In addition to regional variations in EC structure and function, EC can alter their structure and function in normal aging and pathologic states. This is very notable in retina, in which diabetic changes-including de novo expression of ICAM1-have been extensively documented (McLeod et al., 1995).

Less is appreciated about the molecular changes occurring in diseased choriocapillaris. As demonstrated by McLeod et al. (2009) and Biesemeier et al. (2014), choroidal EC dedifferentiation is an event that occurs in advanced AMD, with loss of fenestrae. We 
recently found that normal aging is associated with loss of expression of the cell surface protein CD34 on otherwise normal choriocapillaris EC in human eyes (Sohn et al., 2014a); mining of publically available data sets (Chen et al., 2008; Newman et al., 2012) reveals an overall loss of CD34 expression in aged mouse and human eyes (Sohn et al., 2014a). CD34 is a protein that may act as "molecular Teflon", serving (among the complex set of leukocyte-endothelial cell interactions) as a mechanism to inhibit transmigration of circulating leukocytes (Nielsen and McNagny, 2008). Thus in normal aging of the choriocapillaris, one tool of the vasculature to limit inflammation is attenuated.

In more extreme situations, choroidal endothelial cells can further alter their phenotype. In a lectin histochemical screen of normal and pathologic vasculature in human eyes, we found that soybean agglutinin binding glycoconjugates were upregulated on the cell surface of neovascular endothelial cells, whereas these molecules were largely absent from normal choroid (Mullins et al., 2005). Since these soybean agglutinin binding glycoconjugates are extractable with organic solvents, they are most likely cell surface glycolipids. In addition, antibodies directed against integrin alpha-v beta- 5 heterodimers have been reported to be abundantly expressed on pathologic endothelium in CNVMs but not on normal endothelial cells (Friedlander et al., 1996).

Thus, in both normal aging and end stage, neovascular AMD, choroidal EC can alter their phenotype. The molecular basis and the mechanistic importance of these changes to macular pathophysiology remains to be determined, although sublytic complement mediated injury could be a contributing factor.

\section{Model for AMD pathogenesis}

In our view, the notion that MAC leads to choriocapillaris dropout and the subsequent sequelae of AMD is very attractive and fits the most genetic, anatomical, clinical, molecular, and biochemical data. Specifically, we envision the following pathophysiologic series of events (Fig. 15): First, the complement system is activated at the Bruch's membrane/ choriocapillaris zone of the human eye. This deposition is more pronounced in the macula than the periphery (Hageman et al., 2005), which may account for the macular predilection of degeneration. The possible purpose and mechanism of complement activation, probably through the alternative pathway, is not fully appreciated. With increasing age, the deposition of MAC accelerates but without major damage to the choriocapillaris or RPE. Due to its altered interactions with CFI, CRP, heparin or other moieties, $\mathrm{CFH}$ molecules harboring a histidine instead of a tyrosine at residue 402 are less efficient at inhibiting the terminal complement pathway. As a result, eyes that are homozygous for the high-risk $\mathrm{CFH}$ genotypes $\mathrm{Y} 402 \mathrm{H}$ generate more MAC complexes in the choroid regardless of age, compared to eyes with low-risk genotypes (Mullins et al., 2011a). At the generation of each MAC complex, a molecule of C5a is released, resulting in increased expression of VEGF by the RPE (Nozaki et al., 2006), upregulation of ICAM-1 on the choriocapillaris (Skeie et al., 2010) and leukocyte recruitment and activation (Liu et al., 2011). In conjunction with these data, our findings that AREDS vitamins inhibit monocyte-EC interactions and suppress de novo expression of ICAM1 in human choroid organ cultures suggests a mechanism whereby AREDS vitamins may protect against AMD progression (Zeng et al., 2012).

Prog Retin Eye Res. Author manuscript; available in PMC 2016 March 01. 
These potentially early events account for the histological observation in human eyes of elevated MAC and increased macrophage (Cherepanoff et al., 2010) and other leukocyte populations (Ezzat et al., 2008; Murinello et al., 2014) in the choroid. While the inflammatory circulating cells are present in increased numbers in the choroid in both dry AMD as well as in choroidal neovascular membranes (Grossniklaus et al., 2002), their precise contribution to pathology of the posterior pole is not well understood. However, it is notable that macrophages may be a source of proangiogenic molecules such as VEGF (Grossniklaus et al., 2002) and angiogenin (Pavlov et al., 2014) and can themselves synthesize additional complement molecules (Rutar et al., 2014), and cytokines that are cytotoxic to neural retina and RPE, such as IL-17, which is elevated in AMD maculas (Ardeljan et al., 2014).

In addition to its role in promoting the inflammatory milieu, the main function of the membrane attack complex is cytolysis. There are a number of reasons to suspect that the creation of MAC leads to choriocapillaris loss. As noted above, the MAC is present from an early age and is localized to the choriocapillaris. This pattern of deposition is consistent across studies and in different laboratories (for example, (Hageman et al., 2005; Seth et al., 2008; Skeie et al., 2010)) and has been sufficiently reproducibly observed that there is little doubt that choriocapillaris is the main site of MAC deposition. Choroidal endothelial cells are susceptible to MAC mediated cell death (unpublished data) and may be more at risk to MAC lysis due to more limited repertoire of complement inhibiting cell surface molecules, compared to the RPE. Evidence for pronounced loss of the choriocapillaris has been documented in AMD using a variety of different methodologies, discussed above. During aging, the normal turnover of endothelial cells is also impaired, such that the replacement of lost endothelium becomes less efficient over several decades (Wang and Bennet, 2012).

We feel that since MAC is capable of inducing cell death and is robustly present at the level of the choriocapillaris, it is the most likely "smoking gun" for endothelial cell death in the choriocapillaris. Whether choriocapillaris loss occurs in AMD due to MAC or some other mechanism, it is clear that this damage occurs.

These changes are also occurring in the context of reduced regulatory potential from the central nervous system-decreased parasympathetic innervation of the choroid has been described in aging in both pigeons (Fitzgerald et al., 2005) and man (Jablonski et al., 2007).

Although we believe the most pronounced changes are occurring at the level of the microvasculature of the choroid, pathology of large vessels has also been suggested based on measurements of scleral rigidity, with increased resistance in the vortex veins, reflux and damage to the choriocapillaris and, ultimately, RPE atrophy (Friedman et al., 1989).

As discussed above, all of these changes in the choroid are accompanied by age-related release of RPE-derived lipid into Bruch's membrane. If the choriocapillaris has a normal role in clearance of this material, dead or dysfunctional endothelial cells fail to remove this debris, resulting in the focal accumulation of lipid that will ultimately form drusen and basal deposits.

Prog Retin Eye Res. Author manuscript; available in PMC 2016 March 01. 
Thus, we propose that a choroid-first hypothesis for the pathogenesis of AMD synthesizes genetic, immunohistochemical, morphometric, molecular, biochemical, functional, and clinical (OCT) data. A cartoon depiction of the events leading to RPE and photoreceptor atrophy is shown in Fig. 15.

Post hoc ergo propter hoc? The most obvious objection to this model is that-while we can observe choriocapillaris loss in advance of RPE loss-it remains challenging to formally demonstrate the cause and effect relationship between deposits in Bruch's membrane and choriocapillaris loss by histology alone. One might argue that drusen form without respect to the disposition of the choriocapillaris, but that the presence of even small drusen, once established, causes a loss of trophic support for the choriocapillaris from the RPE, with subsequent atrophy of the former.

Indeed, RPE-derived VEGF is necessary for the maintenance of the choriocapillaris. Elegant genetic and biochemical studies in mice have shown that immune neutralization (Ford et al., 2011), conditional ablation of soluble VEGF isoforms (Saint-Geniez et al., 2009), and specific deletion of the VEGF gene in RPE cells results in choriocapillaris dedifferentiation (including changes in gene expression and loss of fenestrations) and atrophy (Kurihara et al., 2012). Thus, an intact and functional RPE cell layer is essential for the persistent function of the choriocapillaris.

Studies of developing human eyes have shown that, while the deeper choroidal vessels develop by angiogenesis, the cells of the presumptive choriocapillaris proliferate and differentiate in situ through a process called hemovasculogenesis (Allende et al., 2006; Hasegawa et al., 2007; Lutty et al., 2010). In this process, both the EC and hematopoietic cells are formed locally from the same mesenchymal progenitors. In mouse, secretion of VEGF by the RPE precedes even pigmentation of the RPE by 2 days (Saint-Geniez et al., 2006). In terms of understanding the relationship between the RPE and choriocapillaris, it is therefore significant that vasculogenesis implies that the choriocapillaris is never NOT under influence of the RPE.

In light of this relationship, it is difficult to rule out that the loss of the choriocapillaris may be due to Bruch's membrane changes that interfere with RPE trophic support. Thus, even though loss of choriocapillaris occurs in advance of RPE loss, establishing the primacy of choriocapillaris loss over RPE dysfunction will require additional experiments.

While the relationship between drusen and ghost vessels might feasibly be due to loss of trophic support by the RPE, we propose that the association of drusen with both ghost vessels and inter-capillary pillars is of high significance to model building. Choriocapillaris pillars cannot be readily attributed to a dependency on trophic support from the RPE. In other words, the two choroidal structures associated with drusen-intercapillary pillars and ghost vessels-have the common features of no flow and no viable endothelial cell.

Further work clearly needs to be performed to clarify the chicken-egg question of whether the vascular loss that occurs in early AMD precedes, or follows, the formation of Bruch's membrane deposits. Experiments to ablate the choriocapillaris in model organisms will be very helpful for providing new information about the timing of these events. Although mice

Prog Retin Eye Res. Author manuscript; available in PMC 2016 March 01. 
have not, to date, been shown to develop what a strict human pathologist would unreservedly call "drusen", there are a number of models that show Bruch's membrane abnormalities and accumulation of subRPE material (e.g., (Malek et al., 2005); see the thorough review by Pennesi et al. (2012)). Ablation of different populations of choroidal endothelial cells and studying the downstream effect on temperature, hypoxia and lipid accumulation in Bruch's membrane will shed new light on this question. These studies are underway.

\section{Future directions}

The notion that AMD is a disease with its earliest molecular and cellular events at the level of choriocapillaris endothelial cells has important ramifications for both how existing interventions work and how new therapies should be developed. We envision that several major areas of investigation are necessary.

One discipline that is seeing exciting developments is the improved ability to image the choroid. Early studies, limited to fundus exam, were hampered by the ophthalmologist's inability to consistently image the choroid beneath the RPE pigment but were still able to provide some insight into choroidal pathophysiology. Current state of the art imaging modalities and algorithms are opening the previously closed door to this crucial vascular tissue.

As discussed above, retina clinics can now routinely assess choroidal thickness, using EDIOCT (recently reviewed in (Skondra et al., 2012)). This field is seeing exponential growth in manuscripts pertaining to choroidal thickness in retinal diseases like AMD, central serous chorioretinopathy, as well as glaucoma and diabetic retinopathy (reviewed in (Mrejen and Spaide, 2013)).

While larger vascular elements of the choroid have been revealed using these modalities, assessment of the choriocapillaris has remained a major challenge due to the resolution of current instruments. We recently addressed this challenge by quantifying the "choriocapillaris equivalent thickness" as the distance between resolvable large vessels of the choroid and the clearly-visible Bruch's membrane using an automated 3D algorithm (Zhang et al., 2012a). In addition, the development of novel modalities such as swept source OCT and phase variance OCT is beginning to provide images of the choroidal microvasculature and revealing previously invisible changes in the choroid in central serous chorioretinopathy (Ferrara et al., 2014) and in advance of geographic atrophy (Schwartz et al., 2014). The ongoing development of these tools, and their implementation in AMD and with respect to different genotypes, will be a major step forward in understanding the timing of events involving photoreceptor cells, the RPE and the choroid in AMD.

In terms of therapeutic directions, this model of AMD pathogenesis also offers several important considerations. For patients with early AMD who still have a functional and intact choriocapillaris, rescuing the endangered endothelium from ongoing injury from the complement system may be of great benefit from limiting capillary dropout and buttressing the macula against further damage. Experiments showing that AREDS vitamins are antiinflammatory in the human choriocapillaris suggest a mechanism by which this intervention 
is beneficial in AMD (Zeng et al., 2012). Studies by the Rohrer et al. (2012) and KumarSingh (Lipo et al., 2013) laboratories have made excellent progress in advancing potential therapies for AMD that attenuate complement activation, using both small molecule and gene therapy based approaches (e.g., (Birke et al., 2014)). A prediction of this model is that therapies that inhibit complement activation in the posterior pole, if applied early enough, will prevent choriocapillaris loss, deposition of material in Bruch's membrane, and RPE atrophy.

A second major implication of the notion that the choriocapillaris is lost early in AMD is related to stem cell replacement therapy. Eyes with advanced AMD show loss of the interdependent layers of photoreceptor cells, RPE and choriocapillaris. While considerable effort has been turned toward the generation of RPE cells for therapy in AMD, and excellent progress is being made in the generation of photoreceptor cells for the treatment of inherited retinal diseases, relatively little effort has gone into the replacement of choriocapillaris endothelial cells. Although the neural retina, when healthy, enjoys somewhat of an immune privileged status, we and others have argued that in retinal diseases (and especially AMD) the blood retinal barrier is severely compromised (Tucker et al., 2014). However, even if the host can tolerate retina and even RPE cells following allogenic transplant, the active baseline immune state of the choriocapillaris, and its constant exposure to the immune system, will require careful matching of MHC alleles. In the ideal case, autologous iPSCderived endothelial cells expressing host MHC class I alleles will be used to replace choriocapillaris cells lost to complement mediated cytolysis. In the case of advanced AMD, with atrophy of photoreceptor cells, RPE and choriocapillaris, modular reassembly of the missing cell layers may be required.

\section{Conclusion}

In summary, the choriocapillaris is a unique and vital support structure for the macular retina and RPE. It is the key site of MAC deposition and undergoes degenerative changes early in association with AMD pathogenesis. We propose that a comprehensive treatment strategy for early and late AMD will need to include defense and repair of this fundamentally important tissue.

\section{Acknowledgments}

The authors wish to thank the Iowa Lions Eye Bank and the many eye donors and their families who have thoughtfully donated their tissues to the benefit of everyone affected by eye diseases. We also wish to acknowledge the excellent technical assistance of Ms. Megan Riker, Mr. Miles Flamme-Wiese, Dr. Shemin Zeng, Dr. Grefachew Workamelahu, Mr. Christopher Barnard, Ms. Olivia Gibbs, and Mr. Michael Moriarty. Supported in part by the National Eye Institute grants EY-016822 (EMS) and EY-024605 (RFM/BAT), the National Institutes of Health grant 1DP2OD007483 (BAT), the Elmer and Sylvia Sramek Charitable Foundation, and the Hansjoerg E.J.W. Kolder M.D., Ph.D. Professorship for Best Disease Research.

Supported

Supported in part by the National Eye Institute grants EY-016822 (EMS) and EY-024605 (RFM/BAT), the National Institutes of Health grant 1DP2OD007483 (BAT), the Elmer and Sylvia Sramek Charitable Foundation, and the Martin and Ruth Carver Chair in Ocular Cell Biology.

Prog Retin Eye Res. Author manuscript; available in PMC 2016 March 01. 


\section{Abbreviations}

$\begin{array}{ll}\text { AMD } & \text { age-related macular degeneration } \\ \text { AREDS } & \text { age-related eye disease study } \\ \text { CCP } & \text { complement control protein domain } \\ \text { CFH } & \text { complement factor H (gene or protein) } \\ \text { CNV } & \text { choroidal neovascularization } \\ \text { CNVM(s) } & \text { choroidal neovascular membrane(s) } \\ \text { CRP } & \text { C-reactive protein } \\ \text { GA } & \text { geographic atrophy } \\ \text { iPSC(s) } & \text { induced pluripotent stem cell(s) } \\ \text { ICAM-1 } & \text { intercellular adhesion molecule-1 } \\ \text { MAC } & \text { membrane attack complex } \\ \text { OCT } & \text { optical coherence tomography } \\ \text { RPE } & \text { retinal pigment epithelium } \\ \text { SNP } & \text { single nucleotide polymorphism }\end{array}$

\section{References}

Abi-Hanna D, Wakefield D, Watkins S. HLA antigens in ocular tissues. I. In vivo expression in human eyes. Transplantation. 1988; 45:610-613. [PubMed: 3347938]

Ablonczy Z, Dahrouj M, Marneros AG. Progressive dysfunction of the retinal pigment epithelium and retina due to increased VEGF-A levels. FASEB J. 2014; 28:2369-2379. http://dx.doi.org/ 10.1096/fj.13-248021. [PubMed: 24558195]

Age-Related Eye Disease Study 2 Research Group. Lutein + zeaxanthin and omega-3 fatty acids for age-related macular degeneration: the Age-Related Eye Disease Study 2 (AREDS2) randomized clinical trial. JAMA. 2013; 309:2005-2015. http://dx.doi.org/10.1001/jama.2013.4997. [PubMed: 23644932]

Age-Related Eye Disease Study Research Group. A randomized, placebo-controlled, clinical trial of high-dose supplementation with vitamins $\mathrm{C}$ and $\mathrm{E}$, beta carotene, and zinc for age-related macular degeneration and vision loss: AREDS report no. 8. Arch. Ophthalmol. 2001; 119:1417-1436. [PubMed: 11594942]

Allende A, Madigan MC, Provis JM. Endothelial cell proliferation in the choriocapillaris during human retinal differentiation. Br. J. Ophthalmol. 2006; 90:1046-1051. http://dx.doi.org/10.1136/ bjo.2006.092080. [PubMed: 16613918]

Allikmets R, Shroyer NF, Singh N, Seddon JM, Lewis RA, Bernstein PS, Peiffer A, Zabriskie NA, Li Y, Hutchinson A, Dean M, Lupski JR, Leppert M. Mutation of the Stargardt disease gene (ABCR) in age-related macular degeneration. Science. 1997; 277:1805-1807. [PubMed: 9295268]

Alm A, Bill A. The oxygen supply to the retina. II. Effects of high intraocular pressure and of increased arterial carbon dioxide tension on uveal and retinal blood flow in cats. A study with radioactively labelled microspheres including flow determinations in brain and some other tissues. Acta Physiol. Scand. 1972; 84:306-319. http://dx.doi.org/10.1111/j.1748-1716.1972.tb05182.x. [PubMed: 4553229] 
Ames A. Energy requirements of CNS cells as related to their function and to their vulnerability to ischemia: a commentary based on studies on retina. Can. J. Physiol. Pharmacol. 1992; 70(Suppl. 1):S158-S164. [PubMed: 1295666]

Anderson DH, Radeke MJ, Gallo NB, Chapin EA, Johnson PT, Curletti CR, Hancox LS, Hu J, Ebright JN, Malek G, Hauser MA, Rickman CB, Bok D, Hageman GS, Johnson LV. The pivotal role of the complement system in aging and age-related macular degeneration: hypothesis re-visited. Prog. Retin. Eye Res. 2010; 29:95-112. http://dx.doi.org/10.1016/j.preteyeres.2009.11.003. [PubMed: 19961953]

AREDS2-HOME Study Research Group. Chew EY, Clemons TE, Bressler SB, Elman MJ, Danis RP, Domalpally A, Heier JS, Kim JE, Garfinkel R. Randomized trial of a home monitoring system for early detection of choroidal neovascularization Home Monitoring of the Eye (HOME) study. Ophthalmology. 2014; 121:535-544. http://dx.doi.org/10.1016/j.ophtha.2013.10.027. [PubMed: 24211172]

Ardeljan D, Wang Y, Park S, Shen D, Chu XK, Yu C-R, Abu-Asab M, Tuo J, Eberhart CG, Olsen TW, Mullins RF, White G, Wadsworth S, Scaria A, Chan C-C. Interleukin-17 retinotoxicity is prevented by gene transfer of a soluble interleukin-17 receptor acting as a cytokine blocker: implications for age-related macular degeneration. PLoS One. 2014; 9:e95900. http://dx.doi.org/ 10.1371/journal.pone.0095900. [PubMed: 24780906]

Arnold JJ, Sarks SH, Killingsworth MC, Sarks JP. Reticular pseudodrusen. A risk factor in age-related maculopathy. Retina. 1995; 15:183-191. [PubMed: 7569344]

Arora KS, Jefferys JL, Maul EA, Quigley HA. Choroidal thickness change after water drinking is greater in angle closure than in open angle eyes. Investig. Ophthalmol. Vis. Sci. 2012; 53:63936402. http://dx.doi.org/10.1167/iovs.12-10224. [PubMed: 22918644]

Awh CC, Lane A-M, Hawken S, Zanke B, Kim IK. CFH and ARMS2 genetic polymorphisms predict response to antioxidants and zinc in patients with age-related macular degeneration. Ophthalmology. 2013; 120:2317-2323. http:// dx.doi.org/10.1016/j.ophtha.2013.07.039. [PubMed: 23972322]

Bakall B, Folk JC, Boldt HC, Sohn EH, Stone EM, Russell SR, Mahajan VB. Aflibercept therapy for exudative age-related macular degeneration resistant to bevacizumab and ranibizumab. Am. J. Ophthalmol. 2013; 156:15-22. e1. http://dx.doi.org/10.1016/j.ajo.2013.02.017. [PubMed: 23706500]

Barondes M, Pauleikhoff D, Chisholm IC, Minassian D, Bird AC. Bilaterality of drusen. Br. J. Ophthalmol. 1990; 74:180-182. [PubMed: 2322518]

Bearelly S, Chau FY, Koreishi A, Stinnett SS, Izatt JA, Toth CA. Spectral domain optical coherence tomography imaging of geographic atrophy margins. Ophthalmology. 2009; 116:1762-1769. http://dx.doi.org/10.1016/j.ophtha.2009.04.015. [PubMed: 19643488]

Berenberg TL, Metelitsina TI, Madow B, Dai Y, Ying G-S, Dupont JC, Grunwald L, Brucker AJ, Grunwald JE. The association between drusen extent and foveolar choroidal blood flow in agerelated macular degeneration. Retina (Philadelphia, Pa.). 2012; 32:25-31. http://dx.doi.org/ 10.1097/IAE.0b013-3182150483.

Bexborn F, Andersson PO, Chen H, Nilsson B, Ekdahl KN. The tick-over theory revisited: formation and regulation of the soluble alternative complement $\mathrm{C} 3$ convertase $(\mathrm{C} 3(\mathrm{H} 2 \mathrm{O}) \mathrm{Bb})$. Mol. Immunol. 2008; 45:2370-2379. http://dx.doi.org/10.1016/j.molimm.2007.11.003. [PubMed: 18096230]

Bhutto IA, Baba T, Merges C, Juriasinghani V, McLeod DS, Lutty GA. C-reactive protein and complement factor $\mathrm{H}$ in aged human eyes and eyes with age-related macular degeneration. $\mathrm{Br}$. $\mathrm{J}$. Ophthalmol. 2011; 95:1323-1330. http://dx.doi.org/10.1136/bjo.2010.199216. [PubMed: 21633121]

Biesemeier, A.; Biesemeier, A.; Taubitz, T.; Taubitz, T.; Julien, S.; Julien, S.; Yoeruek, E.; Yoeruek, E.; Schraermeyer, U.; Schraermeyer, U. Neurobiol. 2014. p. 1-42.Accepted Manuscript Aging http://dx.doi.org/10.1016/ j.neurobiolaging.2014.05.003

Bird AC, Bressler NM, Bressler SB, Chisholm IH, Coscas G, Davis MD, de Jong PT, Klaver CC, Klein BE, Klein R. An international classification and grading system for age-related maculopathy and age-related macular degeneration. The International ARM Epidemiological Study Group. Surv. Ophthalmol. 1995; 39:367-374. 
Bird AC, Phillips RL, Hageman GS. Geographic atrophy: a histopatho-logical assessment. JAMA Ophthalmol. 2014; 132:338-345. http://dx.doi.org/10.1001/jamaophthalmol.2013.5799. [PubMed: 24626824]

Birke MT, Lipo E, Adhi M, Birke K, Kumar-Singh R. AAV-mediated expression of human PRELP inhibits complement activation, choroidal neovascularization and deposition of membrane attack complex in mice. Gene Ther. 2014; 21:507-513. http://dx.doi.org/10.1038/gt.2014.24. [PubMed: 24670995]

Birol G, Wang S, Budzynski E, Wangsa-Wirawan ND, Linsenmeier RA. Oxygen distribution and consumption in the macaque retina. Am. J. Physiol. Heart Circ. Physiol. 2007; 293:H1696-H1704. http://dx.doi.org/10.1152/ajpheart.00221.2007. [PubMed: 17557923]

Brechner RJ, Rosenfeld PJ, Babish JD, Caplan S. Pharmacotherapy for neovascular age-related macular degeneration: an analysis of the $100 \% 2008$ medicare fee-for-service part B claims file. Am. J. Ophthalmol. 2011; 151:887-895. e1. http://dx.doi.org/10.1016/j.ajo.2010.11.017. [PubMed: 21310390]

Bressler NM, Doan QV, Varma R, Lee PP, Suñer IJ, Dolan C, Danese MD, Yu E, Tran I, Colman S. Estimated cases of legal blindness and visual impairment avoided using ranibizumab for choroidal neovascularization: non-Hispanic white population in the United States with age-related macular degeneration. Arch. Ophthalmol. 2011; 129:709-717. http://dx.doi.org/10.1001/archophthalmol. 2011.140. [PubMed: 21670337]

Brooks GA, Brooks GA, Hittelman KJ, Hittelman KJ, Faulkner JA, Faulkner JA, Beyer RE, Beyer RE. Temperature, skeletal muscle mitochondrial functions, and oxygen debt. Am. J. Physiol. 1971; 220:1053-1059. [PubMed: 4323901]

Brown DM, Kaiser PK, Michels M, Soubrane G, Heier JS, Kim RY, Sy JP, Schneider S, ANCHOR Study Group. Ranibizumab versus verteporfin for neovascular age-related macular degeneration. N. Engl. J. Med. 2006; 355:1432-1444. http://dx.doi.org/10.1056/NEJMoa062655. [PubMed: 17021319]

Browning AC, Halligan EP, Stewart EA, Swan DC, Dove R, Samaranayake GJ, Amoaku WM. Comparative gene expression profiling of human umbilical vein endothelial cells and ocular vascular endothelial cells. Br. J. Ophthalmol. 2012; 96:128-132. http://dx.doi.org/10.1136/ bjophthalmol-2011-300572. [PubMed: 22028475]

Brunette JR, Grassi MA, Olivier P, Fingert JH, Zaharia M, Scheetz TE, Blondeau P, Roos BR, Lafond G, Ritch R, West SK, Kawase K, Shire AM, Mullins RF, Stone EM. Rod-cone differences in response to retinal ischemia in rabbit. Doc. Ophthalmol. 1986; 63:359-365. [PubMed: 3803167]

Burns MS, Hartz MJ. The retinal pigment epithelium induces fenestration of endothelial cells in vivo. Curr. Eye Res. 1992; 11:863-873. [PubMed: 1424729]

Cao R, Brakenhielm E, Wahlestedt C, Thyberg J, Cao Y. Leptin induces vascular permeability and synergistically stimulates angiogenesis with FGF-2 and VEGF. Proc. Natl. Acad. Sci. U. S. A. 2001; 98:6390-6395. http://dx.doi.org/10.1073/pnas.101564798. [PubMed: 11344271]

Casswell AG, Kohen D, Bird AC. Retinal pigment epithelial detachments in the elderly: classification and outcome. Br. J. Ophthalmol. 1985; 69:397-403. [PubMed: 2408659]

Casten RJ, Rovner BW. Update on depression and age-related macular degeneration. Curr. Opin. Ophthalmol. 2013; 24:239-243. http://dx.doi.org/10.1097/ICU.0b013-32835f8-55. [PubMed: 23429599]

CATT Research Group. Martin DF, Maguire MG, Ying G-S, Grunwald JE, Fine SL, Jaffe GJ. Ranibizumab and bevacizumab for neovascular age-related macular degeneration. N. Engl. J. Med. 2011; 364:1897-1908. http://dx.doi.org/10.1056/NEJMoa1102673. [PubMed: 21526923]

Chan C-C, Shen D, Zhou M, Ross RJ, Ding X, Zhang K, Green WR, Tuo J. Human HtrA1 in the archived eyes with age-related macular degeneration. Trans. Am. Ophthalmol. Soc. 2007; 105:9297. Discussion 97-8. [PubMed: 18427598]

Chen H, Liu B, Lukas TJ, Neufeld AH. The aged retinal pigment epithelium/choroid: a potential substratum for the pathogenesis of age-related macular degeneration. PLoS One. 2008; 3:e2339. http://dx.doi.org/10.1371/journal.pone.0002339. [PubMed: 18523633]

Prog Retin Eye Res. Author manuscript; available in PMC 2016 March 01. 
Cherepanoff S, McMenamin P, Gillies MC, Kettle E, Sarks SH. Bruch's membrane and choroidal macrophages in early and advanced age-related macular degeneration. Br. J. Ophthalmol. 2010; 94:918-925. http://dx.doi.org/10.1136/bjo.2009.165563. [PubMed: 19965817]

Chew, EY.; Klein, ML.; Clemons, TE.; Agron, E.; Ratnapriya, R.; Edwards, AO.; Fritsche, LG.; Swaroop, A.; Abecasis, GR.; Age-Related Eye Disease Study Research Group. No clinically significant association between CFH and ARMS2 genotypes and response to Nutritional Supplements: AREDS report number 38.. Ophthalmology. 2014. http://dx.doi.org/10.1016/ j.ophtha.2014.05.008

Christen WG, Glynn RJ, Manson JE, Ajani UA, Buring JE. A prospective study of cigarette smoking and risk of age-related macular degeneration in men. JAMA. 1996; 276:1147-1151. [PubMed: 8827967]

Chung SE, Kang SW, Lee JH, Kim YT. Choroidal thickness in polypoidal choroidal vasculopathy and exudative age-related macular degeneration. Ophthalmology. 2011; 118:840-845. http:// dx.doi.org/10.1016/j.ophtha.2010.09.012. [PubMed: 21211846]

Clark SJ, Ridge LA, Herbert AP, Hakobyan S, Mulloy B, Lennon R, Würzner R, Morgan BP, Uhrín D, Bishop PN, Day AJ. Tissue-specific host recognition by complement factor $\mathrm{H}$ is mediated by differential activities of its glycosaminoglycan-binding regions. J. Immunol. 2013; 190:20492057. http://dx.doi.org/10.4049/jimmunol.1201751. [PubMed: 23365078]

Clow LA, Raftos DA, Gross PS, Smith LC. The sea urchin complement homologue, SpC3, functions as an opsonin. J. Exp. Biol. 2004; 207:2147-2155. [PubMed: 15143147]

Coleman AL, Yu F. Eye-related medicare costs for patients with age-related macular degeneration from 1995 to 1999. Ophthalmology. 2008; 115:18-25. http://dx.doi.org/10.1016/j.ophtha. 2007.04.016. [PubMed: 17572499]

Congdon N, O'Colmain B, Klaver CCW, Klein R, Muñoz B, Friedman DS, Kempen J, Taylor HR, Mitchell P, Eye Diseases Prevalence Research Group. Causes and prevalence of visual impairment among adults in the United States. Arch. Ophthalmol. 2004; 122:477-485. http://dx.doi.org/ 10.1001/archopht.122.4.477. [PubMed: 15078664]

Crabb JW, Miyagi M, Gu X, Shadrach K, West KA, Sakaguchi H, Kamei M, Hasan A, Yan L, Rayborn ME, Salomon RG, Hollyfield JG. Drusen proteome analysis: an approach to the etiology of age-related macular degeneration. Proc. Natl. Acad. Sci. U. S. A. 2002; 99:14682-14687. http:// dx.doi.org/10.1073/pnas.222551899. [PubMed: 12391305]

Cruickshanks KJ, Klein R, Klein BE, Nondahl DM. Sunlight and the 5-year incidence of early agerelated maculopathy: the beaver dam eye study. Arch. Ophthalmol. 2001; 119:246-250. [PubMed: 11176987]

Cukras C, Agron E, Klein ML, Ferris FL, Chew EY, Gensler G, Wong WT, Age-Related Eye Disease Study Research Group. Natural history of drusenoid pigment epithelial detachment in age-related macular degeneration: age-related eye disease study report no. 28. Ophthalmology. 2010; 117:489-499. http://dx.doi.org/10.1016/j.ophtha.2009.12.002. [PubMed: 20079925]

Curcio CA. Photoreceptor topography in ageing and age-related maculopathy. Eye (Lond.). 2001; 15:376-383. http://dx.doi.org/10.1038/eye.2001.140. [PubMed: 11450761]

Curcio CA, Johnson M, Huang J-D, Rudolf M. Aging, age-related macular degeneration, and the response-to-retention of apolipoprotein B-containing lipoproteins. Prog. Retin. Eye Res. 2009; 28:393-422. http://dx.doi.org/10.1016/j.preteyeres.2009.08.001. [PubMed: 19698799]

Curcio CA, Johnson M, Huang J-D, Rudolf M. Apolipoprotein B-containing lipoproteins in retinal aging and age-related macular degeneration. J. Lipid Res. 2010; 51:451-467. http://dx.doi.org/ 10.1194/jlr.R002238. [PubMed: 19797256]

Curcio CA, Johnson M, Rudolf M, Huang J-D. The oil spill in ageing Bruch membrane. Br. J. Ophthalmol. 2011; 95:1638-1645. http://dx.doi.org/10.1136/bjophthalmol-2011-300344. [PubMed: 21890786]

Curcio CA, Messinger JD, Sloan KR, McGwin G, Medeiros NE, Spaide RF. Subretinal drusenoid deposits in non-neovascular age-related macular degeneration: morphology, prevalence, topography, and biogenesis model. Retina (Philadelphia, Pa.). 2013; 33:265-276. http://dx.doi.org/ 10.1097/IAE.0b013-31827-25-0.

Prog Retin Eye Res. Author manuscript; available in PMC 2016 March 01. 
Curcio CA, Millican CL. Basal linear deposit and large drusen are specific for early age-related maculopathy. Arch. Ophthalmol. 1999; 117:329-339. [PubMed: 10088810]

Curcio CA, Presley JB, Millican CL, Medeiros NE. Basal deposits and drusen in eyes with age-related maculopathy: evidence for solid lipid particles. Exp. Eye Res. 2005; 80:761-775. http://dx.doi.org/ 10.1016/j.exer.2004.09.017. [PubMed: 15939032]

Curcio CA, Sloan KR, Kalina RE, Hendrickson AE. Human photoreceptor topography. J. Comp. Neurol. 1990; 292:497-523. http://dx.doi.org/10.1002/cne.902920402. [PubMed: 2324310]

Davis MD, Gangnon RE, Lee L-Y, Hubbard LD, Klein BEK, Klein R, Ferris FL, Bressler SB, Milton RC, Age-Related Eye Disease Study Group. The age-related eye disease study severity scale for age-related macular degeneration: AREDS report No. 17. Arch. Ophthalmol. 2005; 123:14841498. http://dx.doi.org/10.1001/archopht.123.11.1484. [PubMed: 16286610]

Deangelis MM, Ji F, Adams S, Morrison MA, Harring AJ, Sweeney MO, Capone A, Miller JW, Dryja TP, Ott J, Kim IK. Alleles in the HtrA serine peptidase 1 gene alter the risk of neovascular agerelated macular degeneration. Ophthalmology. 2008; 115:1209-1215. e7. http://dx.doi.org/ 10.1016/j.ophtha.2007.10.032. [PubMed: 18164066]

Degn SE, Thiel S, Jensenius JC. New perspectives on mannan-binding lectin-mediated complement activation. Immunobiology. 2007; 212:301-311. http://dx.doi.org/10.1016/j.imbio.2006.12.004. [PubMed: 17544815]

Del Priore LV, Kuo Y-H, Tezel TH. Age-related changes in human RPE cell density and apoptosis proportion in situ. Investig. Ophthalmol. Vis. Sci. 2002; 43:3312-3318. [PubMed: 12356840]

Dewan A, Driscoll JJ, Zeng F, Liu M, Chowdhury RD, Zhang M, Hartman S, Xu Y, Zhang SS-M, Xu H, Liu DTL, Zhao C, Tam POS, Chan WM, Lam DSC, Snyder M, Barnstable C, Pang CP, Hoh J. HTRA1 promoter polymorphism in wet age-related macular degeneration. Science. 2006; 314:989-992. http://dx.doi.org/10.1126/science.1133807. [PubMed: 17053108]

Do DV, Pieramici DJ, van Lookeren Campagne M, Beres T, Friesenhahn M, Zhang Y, Strauss EC, Phase Ia Investigators. A phase ia dose-escalation study of the anti-factor D monoclonal antibody fragment FCFD4514S in patients with geographic atrophy. Retina (Philadelphia, Pa.). 2014; 34:313-320. http://dx.doi.org/10.1097/IAE.0b013-3182979ddd.

Ducruet AF, Zacharia BE, Hickman ZL, Grobelny BT, Yeh ML, Sosunov SA, Connolly ES. The complement cascade as a therapeutic target in intra-cerebral hemorrhage. Exp. Neurol. 2009; 219:398-403. http://dx.doi.org/10.1016/j.expneurol.2009.07.018. [PubMed: 19632224]

Ebrahem Q, Renganathan K, Sears J, Vasanji A, Gu X, Lu L, Salomon RG, Crabb JW, Anand-Apte B. Carboxyethylpyrrole oxidative protein modifications stimulate neovascularization: Implications for age-related macular degeneration. Proc. Natl. Acad. Sci. U. S. A. 2006; 103:13480-13484. http://dx.doi.org/10.1073/pnas.0601552103. [PubMed: 16938854]

Ebrahimi KB, Fijalkowski N, Cano M, Handa JT. Decreased membrane complement regulators in the retinal pigmented epithelium contributes to age-related macular degeneration. J. Pathol. 2013; 229:729-742. http://dx.doi.org/10.1002/path.4128. [PubMed: 23097248]

Edwards AO, Ritter R, Abel KJ, Manning A, Panhuysen C, Farrer LA. Complement factor H polymorphism and age-related macular degeneration. Science. 2005; 308:421-424. http:// dx.doi.org/10.1126/science.1110189. [PubMed: 15761121]

Eisenhardt SU, Habersberger J, Murphy A, Chen Y-C, Woollard KJ, Bassler N, Qian H, Zur Muhlen von C, Hagemeyer CE, Ahrens I, Chin-Dusting J, Bobik A, Peter K. Dissociation of pentameric to monomeric C-reactive protein on activated platelets localizes inflammation to atherosclerotic plaques. Circ. Res. 2009; 105:128-137. http://dx.doi.org/10.1161/CIRCRESAHA.108.190611. [PubMed: 19520972]

Eklund CM. Proinflammatory cytokines in CRP baseline regulation. Adv. Clin. Chem. 2009; 48:111136. [PubMed: 19803417]

Eye Disease Case-Control Study Group. Antioxidant status and neovascular age-related macular degeneration. Arch. Ophthalmol. 1993; 111:104-109. [PubMed: 7678730]

Ezzat MK, Hann CR, Vuk-Pavlovic S, Pulido JS. Immune cells in the human choroid. Br. J. Ophthalmol. 2008; 92:976-980. http://dx.doi.org/10.1136/bjo.2007.129742. [PubMed: 18577650]

Fagerness JA, Fagerness JA, Maller JB, Maller JB, Neale BM, Neale BM, Reynolds RC, Reynolds RC, Daly MJ, Daly MJ, Seddon JM, Seddon JM. Variation near complement factor I is associated 
with risk of advanced AMD. Eur. J. Hum. Genet. 2009; 17:100-104. http://dx.doi.org/10.1038/ ejhg.2008.140. [PubMed: 18685559]

Ferrara D, Mohler KJ, Waheed N, Adhi M, Liu JJ, Grulkowski I, Kraus MF, Baumal C, Hornegger J, Fujimoto JG, Duker JS. En face enhanced-depth swept-source optical coherence tomography features of chronic central serous chorioretinopathy. Ophthalmology. 2014; 121:719-726. http:// dx.doi.org/10.1016/j.ophtha.2013.10.014. [PubMed: 24289918]

Ferris FL, Davis MD, Clemons TE, Lee L-Y, Chew EY, Lindblad AS, Milton RC, Bressler SB, Klein R, Age-Related Eye Disease Study (AREDS) Research Group. A simplified severity scale for agerelated macular degeneration: AREDS report no. 18. Arch. Ophthalmol. 2005; 123:1570-1574. http://dx.doi.org/10.1001/archopht.123.11.1570. [PubMed: 16286620]

Ferris FL, Fine SL, Hyman L. Age-related macular degeneration and blindness due to neovascular maculopathy. Arch. Ophthalmol. 1984; 102:1640-1642. [PubMed: 6208888]

Ferris FL, Wilkinson CP, Bird A, Chakravarthy U, Chew E, Csaky K, Sadda SR, Beckman Initiative for Macular Research Classification Committee. Clinical classification of age-related macular degeneration. Ophthalmology. 2013; 120:844-851. http://dx.doi.org/10.1016/j.ophtha. 2012.10.036. [PubMed: 23332590]

Fett AL, Hermann MM, Muether PS, Kirchhof B, Fauser S. Immunohistochemical localization of complement regulatory proteins in the human retina. Histol. Histopathol. 2012; 27:357-364. [PubMed: 22237713]

Filep JG. Platelets affect the structure and function of C-reactive protein. Circ. Res. 2009; 105:109111. http://dx.doi.org/10.1161/CIRCRESAHA.109.202010. [PubMed: 19608987]

Fine AM, Elman MJ, Ebert JE, Prestia PA, Starr JS, Fine SL. Earliest symptoms caused by neovascular membranes in the macula. Arch. Ophthalmol. 1986; 104:513-514. [PubMed: 2420316]

Fitzgerald MEC, Tolley E, Jackson B, Zagvazdin YS, Cuthbertson SL, Hodos W, Reiner A. Anatomical and functional evidence for progressive age-related decline in parasympathetic control of choroidal blood flow in pigeons. Exp. Eye Res. 2005; 81:478-491. http://dx.doi.org/10.1016/ j.exer.2005.03.008. [PubMed: 15935343]

Fleckenstein M, Charbel Issa P, Helb H-M, Schmitz-Valckenberg S, Finger RP, Scholl HPN, Loeffler KU, Holz FG. High-resolution spectral domain-OCT imaging in geographic atrophy associated with age-related macular degeneration. Investig. Ophthalmol. Vis. Sci. 2008; 49:4137-4144. http://dx.doi.org/10.1167/iovs.08-1967. [PubMed: 18487363]

Flyvbjerg A. Diabetic angiopathy, the complement system and the tumor necrosis factor superfamily. Nat. Rev. Endocrinol. 2010; 6:94-101. http://dx.doi.org/10.1038/nrendo.2009.266. [PubMed: 20098449]

Folk JC. Aging macular degeneration. Clinical features of treatable disease. Ophthalmology. 1985; 92:594-602. [PubMed: 2409501]

Ford KM, Saint-Geniez M, Walshe T, Zahr A, D'Amore PA. Expression and role of VEGF in the adult retinal pigment epithelium. Investig. Ophthalmol. Vis. Sci. 2011; 52:9478-9487. http://dx.doi.org/ 10.1167/iovs.11-8353.

Forooghian F, Stetson PF, Meyer SA, Chew EY, Wong WT, Cukras C, Meyerle CB, Ferris FL. Relationship between photoreceptor outer segment length and visual acuity in diabetic macular edema. Retina (Philadelphia, Pa.). 2010; 30:63-70. http://dx.doi.org/10.1097/IAE. 0b013-3181bd2c5a.

Forrester JV. Macrophages eyed in macular degeneration. Nat. Med. 2003; 9:1350-1351. http:// dx.doi.org/10.1038/nm1103-1350. [PubMed: 14595424]

Francis PJ, Appukuttan B, Simmons E, Landauer N, Stoddard J, Hamon S, Ott J, Ferguson B, Klein M, Stout JT, Neuringer M. Rhesus monkeys and humans share common susceptibility genes for agerelated macular disease. Hum. Mol. Genet. 2008; 17:2673-2680. http://dx.doi.org/10.1093/hmg/ ddn167. [PubMed: 18535016]

Francis PJ, Hamon SC, Ott J, Weleber RG, Klein ML. Polymorphisms in C2, CFB and C3 are associated with progression to advanced age related macular degeneration associated with visual loss. J. Med. Genet. 2009; 46:300-307. http://dx.doi.org/10.1136/jmg.2008.062737. [PubMed: 19015224] 
Friedlander M, Theesfeld CL, Sugita M, Fruttiger M, Thomas MA, Chang S, Cheresh DA. Involvement of integrins alpha $v$ beta 3 and alpha $v$ beta 5 in ocular neovascular diseases. Proc. Natl. Acad. Sci. U. S. A. 1996; 93:9764-9769. [PubMed: 8790405]

Friedman DS, O'Colmain BJ, Muñoz B, Tomany SC, McCarty C, de Jong PTVM, Nemesure B, Mitchell P, Kempen J, Eye Diseases Prevalence Research Group. Prevalence of age-related macular degeneration in the United States. Arch. Ophthalmol. 2004; 122:564-572. http:// dx.doi.org/10.1001/archopht.122.4.564. [PubMed: 15078675]

Friedman E, Ivry M, Ebert E, Glynn R, Gragoudas E, Seddon J. Increased scleral rigidity and agerelated macular degeneration. Ophthalmology. 1989; 96:104-108. [PubMed: 2919041]

Friedman E, Smith TR, Kuwabara T. Senile choroidal vascular patterns and drusen. Arch. Ophthalmol. 1963; 69:220-230. [PubMed: 13959793]

Friedrich U, Myers CA, Fritsche LG, Milenkovich A, Wolf A, Corbo JC, Weber BHF. Risk- and nonrisk-associated variants at the 10q26 AMD locus influence ARMS2 mRNA expression but exclude pathogenic effects due to protein deficiency. Hum. Mol. Genet. 2011; 20:1387-1399. http:// dx.doi.org/10.1093/hmg/ddr020. [PubMed: 21252205]

Fritsche LG, Chen W, Schu M, Yaspan BL, Yu Y, Thorleifsson G, Zack DJ, Arakawa S, Cipriani V, Ripke S, Igo RP, Buitendijk GHS, Sim X, Weeks DE, Guymer RH, Merriam JE, Francis PJ, Hannum G, Agarwal A, Armbrecht AM, Audo I, Aung T, Barile GR, Benchaboune M, Bird AC, Bishop PN, Branham KE, Brooks M, Brucker AJ, Cade WH, Cain MS, Campochiaro PA, Chan CC, Cheng C-Y, Chew EY, Chin KA, Chowers I, Clayton DG, Cojocaru R, Conley YP, Cornes BK, Daly MJ, Dhillon B, Edwards AO, Evangelou E, Fagerness J, Ferreyra HA, Friedman JS, Geirsdottir A, George RJ, Gieger C, Gupta N, Hagstrom SA, Harding SP, Haritoglou C, Heckenlively JR, Holz FG, Hughes G, Ioannidis JPA, Ishibashi T, Joseph P, Jun G, Kamatani Y, Katsanis N, N Keilhauer C, Khan JC, Kim IK, Kiyohara Y, Klein BEK, Klein R, Kovach JL, Kozak I, Lee CJ, Lee KE, Lichtner P, Lotery AJ, Meitinger T, Mitchell P, Mohand-Saïd S, Moore AT, Morgan DJ, Morrison MA, Myers CE, Naj AC, Nakamura Y, Okada Y, Orlin A, Ortube MC, Othman MI, Pappas C, Park KH, Pauer GJT, Peachey NS, Poch O, Priya RR, Reynolds R, Richardson AJ, Ripp R, Rudolph G, Ryu E, Sahel J-A, Schaumberg DA, Scholl HPN, Schwartz SG, Scott WK, Shahid H, Sigurdsson H, Silvestri G, Sivakumaran TA, Smith RT, Sobrin L, Souied EH, Stambolian DE, Stefansson H, Sturgill-Short GM, Takahashi A, Tosakulwong N, Truitt BJ, Tsironi EE, Uitterlinden AG, van Duijn CM, Vijaya L, Vingerling JR, Vithana EN, Webster AR, Wichmann H-E, Winkler TW, Wong TY, Wright AF, Zelenika D, Zhang M, Zhao L, Zhang K, Klein ML, Hageman GS, Lathrop GM, Stefansson K, Allikmets R, Baird PN, Gorin MB, Wang JJ, Klaver CCW, Seddon JM, Pericak-Vance MA, Iyengar SK, Yates JRW, Swaroop A, Weber BHF, Kubo M, Deangelis MM, Léveillard T, Thorsteinsdottir U, Haines JL, Farrer LA, Heid IM, Abecasis GR, AMD Gene Consortium. Seven new loci associated with age-related macular degeneration. Nat. Genet. 2013; 45:433-439. 439e1-2. http://dx.doi.org/10.1038/ng.2578. [PubMed: 23455636]

Fritsche LG, Loenhardt T, Janssen A, Fisher SA, Rivera A, Keilhauer CN, Weber BHF. Age-related macular degeneration is associated with an unstable ARMS2 (LOC387715) mRNA. Nat. Genet. 2008; 40:892-896. http://dx.doi.org/10.1038/ng.170. [PubMed: 18511946]

Gabay C, Kushner I. Acute-phase proteins and other systemic responses to inflammation. N. Engl. J. Med. 1999; 340:448-454. http://dx.doi.org/10.1056/NEJM199902113400607. [PubMed: 9971870]

Gass JD, Jallow S, Davis B. Adult vitelliform macular detachment occurring in patients with basal laminar drusen. Am. J. Ophthalmol. 1985; 99:445-459. [PubMed: 3985082]

Gass JDM. Drusen and disciform macular detachment and degeneration. Arch. Ophthalmol. 1973; 90:206-217. [PubMed: 4738143]

Giani A, Pellegrini M, Carini E, Peroglio Deiro A, Bottoni F, Staurenghi G. The dark atrophy with indocyanine green angiography in Stargardt disease. Investig. Ophthalmol. Vis. Sci. 2012; 53:3999-4004. http://dx.doi.org/10.1167/iovs.11-9258. [PubMed: 22589445]

Gold B, Merriam JE, Zernant J, Hancox LS, Taiber AJ, Gehrs K, Cramer K, Neel J, Bergeron J, Barile GR, Smith RT, AMD Genetics Clinical Study Group. Hageman GS, Dean M, Allikmets R. Variation in factor B (BF) and complement component 2 (C2) genes is associated with agerelated macular degeneration. Nat. Genet. 2006; 38:458-462. http://dx.doi.org/10.1038/ng1750. [PubMed: 16518403] 
Gordon WC, Bazan NG. Curr. Eye Res. 2013; Mediator lipidomics in ophthalmology: targets for modulation in inflammation, neuroprotection and nerve regeneration.38:995-1005. http:// dx.doi.org/10.3109/02713683.2013.827211. [PubMed: 23981028]

Gotoh N, Nakanishi H, Hayashi H, Yamada R, Otani A, Tsujikawa A, Yamashiro K, Tamura H, Saito M, Saito K, Iida T, Matsuda F, Yoshimura N. ARMS2 (LOC387715) variants in Japanese patients with exudative age-related macular degeneration and polypoidal choroidal vasculopathy. Am. J. Ophthalmol. 2009; 147:1037-1041. 1041, e1-2. http://dx.doi.org/10.1016/j.ajo. 2008.12.036. [PubMed: 19268887]

Gotoh N, Yamashiro K, Nakanishi H, Saito M, Iida T, Yoshimura N. Haplotype analysis of the ARMS2/HTRA1 region in Japanese patients with typical neovascular age-related macular degeneration or polypoidal choroidal vasculopathy. Jpn. J. Ophthalmol. 2010; 54:609-614. http:// dx.doi.org/10.1007/s10384-010-0865-2. [PubMed: 21191724]

Goverdhan SV, Howell MW, Mullins RF, Osmond C, Hodgkins PR, Self J, Avery K, Lotery AJ. Association of HLA class I and class II polymorphisms with age-related macular degeneration. Investig. Ophthalmol. Vis. Sci. 2005; 46:1726-1734. http://dx.doi.org/10.1167/iovs.04-0928. [PubMed: 15851575]

Grassi MA, Fingert JH, Scheetz TE, Roos BR, Ritch R, West SK, Kawase K, Shire AM, Mullins RF, Stone EM. Ethnic variation in AMD-associated complement factor $\mathrm{H}$ polymorphism p.Tyr402His. Hum. Mutat. 2006; 27:921-925. http://dx.doi.org/10.1002/humu.20359. [PubMed: 16865697]

Grassi MA, Folk JC, Scheetz TE, Taylor CM, Sheffield VC, Stone EM. Complement factor H polymorphism p.Tyr402His and cuticular Drusen. Arch. Ophthalmol. 2007; 125:93-97. http:// dx.doi.org/10.1001/archopht.125.1.93. [PubMed: 17210858]

Grossniklaus HE, Ling JX, Wallace TM, Dithmar S, Lawson DH, Cohen C, Elner VM, Elner SG, Sternberg P. Macrophage and retinal pigment epithelium expression of angiogenic cytokines in choroidal neovascularization. Mol. Vis. 2002; 8:119-126. [PubMed: 11979237]

Gu J, Pauer GJT, Yue X, Narendra U, Sturgill GM, Bena J, Gu X, Peachey NS, Salomon RG, Hagstrom SA, Crabb JW, Clinical Genomic and Proteomic AMD Study Group. Assessing susceptibility to age-related macular degeneration with proteomic and genomic biomarkers. Mol. Cell. Proteomics. 2009; 8:1338-1349. http://dx.doi.org/10.1074/mcp.M800453-MCP200. [PubMed: 19202148]

Gu X, Meer SG, Miyagi M, Rayborn ME, Hollyfield JG, Crabb JW, Salomon RG. Carboxyethylpyrrole protein adducts and autoantibodies, biomarkers for age-related macular degeneration. J. Biol. Chem. 2003; 278:42027-42035. http://dx.doi.org/10.1074/ jbc.M305460200. [PubMed: 12923198]

Gupta OP, Brown GC, Brown MM. Age-related macular degeneration: the costs to society and the patient. Curr. Opin. Ophthalmol. 2007; 18:201-205. http://dx.doi.org/10.1097/ICU. 0b013-32810c8df4. [PubMed: 17435426]

Guymer RH, Bird AC, Hageman GS. Cytoarchitecture of choroidal capillary endothelial cells. Investig. Ophthalmol. Vis. Sci. 2004; 45:1660-1666. [PubMed: 15161823]

Guymer RH, Heon E, Lotery AJ, Munier FL, Schorderet DF, Baird PN, McNeil RJ, Haines H, Sheffield VC, Stone EM. Variation of codons 1961 and 2177 of the Stargardt disease gene is not associated with age-related macular degeneration. Arch. Ophthalmol. 2001; 119:745-751. [PubMed: 11346402]

Hageman GS, Anderson DH, Johnson LV, Hancox LS, Taiber AJ, Hardisty LI, Hageman JL, Stockman HA, Borchardt JD, Gehrs KM, Smith RJH, Silvestri G, Russell SR, Klaver CCW, Barbazetto I, Chang S, Yannuzzi LA, Barile GR, Merriam JC, Smith RT, Olsh AK, Bergeron J, Zernant J, Merriam JE, Gold B, Dean M, Allikmets R. A common haplotype in the complement regulatory gene factor $\mathrm{H}(\mathrm{HF} 1 / \mathrm{CFH})$ predisposes individuals to age-related macular degeneration. Proc. Natl. Acad. Sci. U. S. A. 2005; 102:7227-7232. http://dx.doi.org/10.1073/ pnas.0501536102. [PubMed: 15870199]

Hageman GS, Hancox LS, Taiber AJ, Gehrs KM, Anderson DH, Johnson LV, Radeke MJ, Kavanagh D, Richards A, Atkinson J, Meri S, Bergeron J, Zernant J, Merriam J, Gold B, Allikmets R, Dean M, AMD Clinical Study Group. Extended haplotypes in the complement factor H (CFH) and $\mathrm{CFH}-$ related (CFHR) family of genes protect against age-related macular degeneration: 
characterization, ethnic distribution and evolutionary implications. Ann. Med. 2006; 38:592-604. [PubMed: 17438673]

Hageman GS, Luthert PJ, Victor Chong NH, Johnson LV, Anderson DH, Mullins RF. An integrated hypothesis that considers drusen as bio-markers of immune-mediated processes at the RPEBruch's membrane interface in aging and age-related macular degeneration. Prog. Retin. Eye Res. 2001; 20:705-732. [PubMed: 11587915]

Hageman GS, Zhu XL, Waheed A, Sly WS. Localization of carbonic anhydrase IV in a specific capillary bed of the human eye. Proc. Natl. Acad. Sci. U. S. A. 1991; 88:2716-2720. [PubMed: 1901414]

Haines JL, Hauser MA, Schmidt S, Scott WK, Olson LM, Gallins P, Spencer KL, Kwan SY, Noureddine M, Gilbert JR, Schnetz-Boutaud N, Agarwal A, Postel EA, Pericak-Vance MA. Complement factor $\mathrm{H}$ variant increases the risk of age-related macular degeneration. Science. 2005; 308:419-421. http://dx.doi.org/10.1126/science.1110359. [PubMed: 15761120]

Hasegawa T, McLeod DS, Bhutto IA, Prow T, Merges CA, Grebe R, Lutty GA. The embryonic human choriocapillaris develops by hemo-vasculogenesis. Dev. Dyn. 2007; 236:2089-2100. http:// dx.doi.org/10.1002/dvdy.21231. [PubMed: 17654716]

Hayreh SS. Segmental nature of the choroidal vasculature. Br. J. Ophthalmol. 1975; 59:631-648. [PubMed: 812547]

Hayreh SS. In vivo choroidal circulation and its watershed zones. Eye (Lond.). 1990; 4(Pt 2):273-289. http://dx.doi.org/10.1038/eye.1990.39. [PubMed: 2199236]

Heier JS, Brown DM, Chong V, Korobelnik J-F, Kaiser PK, Nguyen QD, Kirchhof B, Ho A, Ogura Y, Yancopoulos GD, Stahl N, Vitti R, Berliner AJ, Soo Y, Anderesi M, Groetzbach G, Sommerauer B, Sandbrink R, Simader C, Schmidt-Erfurth U, VIEW 1 and VIEW 2 Study Groups. Intravitreal aflibercept (VEGF trap-eye) in wet age-related macular degeneration. Ophthalmology. 2012; 119:2537-2548. http://dx.doi.org/10.1016/j.ophtha.2012.09.006. [PubMed: 23084240]

Heon E, Buitendijk GHS, Piguet B, Rochtchina E, Munier F, Myers C, Sneed SR, van Duijn CM, Morgan CM, Lee KE, Forni S, Klein BEK, Pescia G, Meuer SM, Schorderet D, de Jong PTVM, Taylor CM, Holliday EG, Streb LM, Tan AG, Wiles CD, Uitterlinden AG, Nishimura DY, Sivakumaran TS, Sheffield VC, Attia J, Stone EM, Hofman A, Mitchell P, Vingerling JR, Iyengar SK, Janssens ACJW, Wang JJ, Klein R, Klaver CCW. Linkage of autosomal dominant radial drusen (malattia leventinese) to chromosome 2p16-21. Arch. Ophthalmol. 1996; 114:193198. [PubMed: 8573024]

Heurich M, Martínez-Barricarte R, Francis NJ, Roberts DL, Rodríguez de Cordoba S, Morgan BP, Harris CL. Common polymorphisms in C3, factor B, and factor $\mathrm{H}$ collaborate to determine systemic complement activity and disease risk. Proc. Natl. Acad. Sci. U. S. A. 2011; 108:87618766. http://dx.doi.org/10.1073/pnas.1019338108. [PubMed: 21555552]

Hogan MJ. Role of the retinal pigment epithelium in macular disease. Trans. Am. Acad. Ophthalmol. Otolaryngol. 1972; 76:64-80. [PubMed: 5024602]

Hogan, MJ.; Alvarado, JA.; Weddell, JE. An Atlas and Textbook. WB Saunders; Philadelphia, PA.: 1971. Histology of the Human Eye..

Hollyfield JG, Bonilha VL, Rayborn ME, Yang X, Shadrach KG, Lu L, Ufret RL, Salomon RG, Perez VL. Oxidative damage-induced inflammation initiates age-related macular degeneration. Nat. Med. 2008; 14:194-198. http://dx.doi.org/10.1038/nm1709. [PubMed: 18223656]

Holz FG, Wolfensberger TJ, Piguet B, Gross-Jendroska M, Wells JA, Minassian DC, Chisholm IH, Bird AC. Bilateral macular drusen in age-related macular degeneration. Prognosis and risk factors. Ophthalmology. 1994; 101:1522-1528. [PubMed: 8090455]

Hosoya K-I, Tomi M. Advances in the cell biology of transport via the inner blood-retinal barrier: establishment of cell lines and transport functions. Biol. Pharm. Bull. 2005; 28:1-8. [PubMed: 15635153]

Howard KP, Klein BEK, Lee KE, Klein R. Measures of body shape and adiposity as related to incidence of age-related eye diseases: observations from the Beaver Dam Eye Study. Investig. Ophthalmol. Vis. Sci. 2014; 55:2592-2598. http://dx.doi.org/10.1167/iovs.13-13763. [PubMed: 24667857]

Prog Retin Eye Res. Author manuscript; available in PMC 2016 March 01. 
Huang D, Swanson EA, Lin CP, Schuman JS, Stinson WG, Chang W, Hee MR, Flotte T, Gregory K, Puliafito CA. Optical coherence tomography. Science. 1991; 254:1178-1181. [PubMed: 1957169]

Huang J-D, Curcio CA, Johnson M. Morphometric analysis of lipoprotein-like particle accumulation in aging human macular Bruch's membrane. Investig. Ophthalmol. Vis. Sci. 2008; 49:27212727. http://dx.doi.org/10.1167/iovs.07-1196. [PubMed: 18296655]

Huang J-D, Presley JB, Chimento MF, Curcio CA, Johnson M. Age-related changes in human macular Bruch's membrane as seen by quick-freeze/deep-etch. Exp. Eye Res. 2007; 85:202-218. http:// dx.doi.org/10.1016/j.exer.2007.03.011. [PubMed: 17586493]

Hughes AE, Orr N, Esfandiary H, Diaz-Torres M, Goodship T, Chakravarthy U. A common CFH haplotype, with deletion of CFHR1 and CFHR3, is associated with lower risk of age-related macular degeneration. Nat. Genet. 2006; 38:1173-1177. http://dx.doi.org/10.1038/ng1890. [PubMed: 16998489]

Hyman L, Schachat AP, He Q, Leske MC. Hypertension, cardiovascular disease, and age-related macular degeneration. Age-Related macular degeneration risk factors study group. Arch. Ophthalmol. 2000; 118:351-358. [PubMed: 10721957]

Jablonski MM, Iannaccone A, Reynolds DH, Gallaher P, Allen S, Wang X, Reiner A. Age-related decline in VIP-positive parasympathetic nerve fibers in the human submacular choroid. Investig. Ophthalmol. Vis. Sci. 2007; 48:479-485. http://dx.doi.org/10.1167/iovs.06-0972. [PubMed: 17251439]

Jackson GR, Scott IU, Kim IK, Quillen DA, Iannaccone A, Edwards JG. Diagnostic sensitivity and specificity of dark adaptometry for detection of age-related macular degeneration. Investig. Ophthalmol. Vis. Sci. 2014; 55:1427-1431. http://dx.doi.org/10.1167/iovs.13-13745. [PubMed: 24550363]

Jakobsdottir J, Conley YP, Weeks DE, Mah TS, Ferrell RE, Gorin MB. Susceptibility genes for agerelated maculopathy on chromosome 10q26. Am. J. Hum. Genet. 2005; 77:389-407. http:// dx.doi.org/10.1086/444437. [PubMed: 16080115]

Jirarattanasopa P, Ooto S, Tsujikawa A, Yamashiro K, Hangai M, Hirata M, Matsumoto A, Yoshimura N. Assessment of macular choroidal thickness by optical coherence tomography and angiographic changes in central serous chorioretinopathy. Ophthalmology. 2012; 119:16661678. http://dx.doi.org/10.1016/j.ophtha.2012.02.021. [PubMed: 22521082]

Johnson LV, Forest DL, Banna CD, Radeke CM, Maloney MA, Hu J, Spencer CN, Walker AM, Tsie MS, Bok D, Radeke MJ, Anderson DH. Cell culture model that mimics drusen formation and triggers complement activation associated with age-related macular degeneration. Proc. Natl. Acad. Sci. U. S. A. 2011; 108:18277-18282. http://dx.doi.org/10.1073/pnas.1109703108. [PubMed: 21969589]

Johnson LV, Leitner WP, Staples MK, Anderson DH. Complement activation and inflammatory processes in drusen formation and age related macular degeneration. Exp. Eye Res. 2001; 73:887-896. http://dx.doi.org/10.1006/exer.2001.1094. [PubMed: 11846519]

Johnson LV, Ozaki S, Staples MK, Erickson PA, Anderson DH. A potential role for immune complex pathogenesis in drusen formation. Exp. Eye Res. 2000; 70:441-449. http://dx.doi.org/10.1006/ exer.1999.0798. [PubMed: 10865992]

Johnson PT, Betts KE, Radeke MJ, Hageman GS, Anderson DH, Johnson LV. Individuals homozygous for the age-related macular degeneration risk-conferring variant of complement factor $\mathrm{H}$ have elevated levels of CRP in the choroid. Proc. Natl. Acad. Sci. U. S. A. 2006; 103:17456-17461. http://dx.doi.org/10.1073/pnas.0606234103. [PubMed: 17079491]

Jones A, Kumar S, Zhang N, Tong Z, Yang J-H, Watt C, Anderson J, Amrita, Fillerup H, McCloskey M, Luo L, Yang Z, Ambati B, Marc R, Oka C, Zhang K, Fu Y. Increased expression of multifunctional serine protease, HTRA1, in retinal pigment epithelium induces polypoidal choroidal vasculopathy in mice. Proc. Natl. Acad. Sci. U. S. A. 2011; 108:14578-14583. http:// dx.doi.org/10.1073/pnas.1102853108. [PubMed: 21844367]

Jylhävä J, Eklund C, Jylhä M, Hervonen A, Lehtimäki T, Karhunen P, Hurme M. Complement factor $\mathrm{H}$ 402His variant confers an increased mortality risk in Finnish nonagenarians: the vitality $90+$ study. Exp. Gerontol. 2009; 44:297-299. http://dx.doi.org/10.1016/j.exger.2008.10.006. [PubMed: 19000922] 
Kanagasingam Y, Bhuiyan A, Abràmoff MD, Smith RT, Goldschmidt L, Wong TY. Progress on retinal image analysis for age related macular degeneration. Prog. Retin. Eye Res. 2014; 38:2042. http://dx.doi.org/10.1016/j.preteyeres.2013.10.002. [PubMed: 24211245]

Kanda A, Chen W, Othman M, Branham KEH, Brooks M, Khanna R, He S, Lyons R, Abecasis GR, Swaroop A. A variant of mitochondrial protein LOC387715/ARMS2, not HTRA1, is strongly associated with age-related macular degeneration. Proc. Natl. Acad. Sci. U. S. A. 2007; 104:16227-16232. http://dx.doi.org/10.1073/pnas.0703933104. [PubMed: 17884985]

Kay CN, Abràmoff MD, Mullins RF, Kinnick TR, Lee K, Eyestone ME, Chung MM, Sohn EH, Stone EM. Three-dimensional distribution of the vitelliform lesion, photoreceptors, and retinal pigment epithelium in the macula of patients with best vitelliform macular dystrophy. Arch. Ophthalmol. 2012; 130:357-364. http://dx.doi.org/10.1001/archophthalmol.2011.363. [PubMed: 22084158]

Keane PA, Patel PJ, Liakopoulos S, Heussen FM, Sadda SR, Tufail A. Evaluation of age-related macular degeneration with optical coherence tomography. Surv. Ophthalmol. 2012; 57:389-414. http://dx.doi.org/10.1016/j.survophthal.2012.01.006. [PubMed: 22898648]

Khreiss T, József L, Potempa LA, Filep JG. Conformational rearrangement in C-reactive protein is required for proinflammatory actions on human endothelial cells. Circulation. 2004; 109:20162022. http://dx.doi.org/10.1161/01.CIR.0000125527.41598.68. [PubMed: 15051635]

Kim, DY.; Fingler, J.; Zawadzki, RJ.; Park, SS.; Morse, LS.; Schwartz, DM.; Fraser, SE.; Werner, JS. Optical imaging of the chorioretinal vasculature in the living human eye.. Proc. Natl. Acad. Sci. U. S. A. 2013. http://dx.doi.org/10.1073/pnas.1307315110

Klein ML, Ferris FL, Armstrong J, Hwang TS, Chew EY, Bressler SB, Chandra SR, AREDS Research Group. Retinal precursors and the development of geographic atrophy in age-related macular degeneration. Ophthalmology. 2008; 115:1026-1031. http://dx.doi.org/10.1016/j.ophtha. 2007.08.030. [PubMed: 17981333]

Klein ML, Schultz DW, Edwards A, Matise TC, Rust K, Berselli CB, Trzupek K, Weleber RG, Ott J, Wirtz MK, Acott TS. Age-related macular degeneration. Clinical features in a large family and linkage to chromosome 1q. Arch. Ophthalmol. 1998; 116:1082-1088. [PubMed: 9715689]

Klein R, Davis MD, Magli YL, Segal P, Klein BE, Hubbard L. The Wisconsin age-related maculopathy grading system. Ophthalmology. 1991; 98:1128-1134. [PubMed: 1843453]

Klein R, Klein BEK, Knudtson MD, Meuer SM, Swift M, Gangnon RE. Fifteen-year cumulative incidence of age-related macular degeneration: the Beaver Dam Eye Study. Ophthalmology. 2007; 114:253-262. http://dx.doi.org/10.1016/j.ophtha.2006.10.040. [PubMed: 17270675]

Klein RJ, Zeiss C, Chew EY, Tsai JY, Sackler RS. Complement factor H polymorphism in age-related macular degeneration. Science. 2005; 308:385-389. http://dx.doi.org/10.1126/science.1109557. [PubMed: 15761122]

Kortvely E, Hauck SM, Duetsch G, Gloeckner CJ, Kremmer E, Alge-Priglinger CS, Deeg CA, Ueffing M. ARMS2 is a constituent of the extracellular matrix providing a link between familial and sporadic age-related macular degenerations. Investig. Ophthalmol. Vis. Sci. 2010; 51:79-88. http://dx.doi.org/10.1167/iovs.09-3850. [PubMed: 19696174]

Kubista KE, Tosakulwong N, Wu Y, Ryu E, Roeder JL, Hecker LA, Baratz KH, Brown WL, Edwards AO. Copy number variation in the complement factor H-related genes and age-related macular degeneration. Mol. Vis. 2011; 17:2080-2092. [PubMed: 21850184]

Kurihara T, Westenskow PD, Bravo S, Aguilar E, Friedlander M. Targeted deletion of Vegfa in adult mice induces vision loss. J. Clin. Investig. 2012; 122:4213-4217. http://dx.doi.org/10.1172/ JCI65157. [PubMed: 23093773]

Laine M, Jarva H, Seitsonen S, Haapasalo K, Lehtinen MJ, Lindeman N, Anderson DH, Johnson PT, Järvelä I, Jokiranta TS, Hageman GS, Immonen I, Meri S. Y402H polymorphism of complement factor $\mathrm{H}$ affects binding affinity to C-reactive protein. J. Immunol. 2007; 178:3831-3836. [PubMed: 17339482]

Langford-Smith, A.; Keenan, TDL.; Clark, SJ.; Bishop, PN.; Day, AJ. The role of complement in agerelated macular degeneration: heparan sulphate, a ZIP code for complement factor H? J. Innate Immun.. 2013. http://dx.doi.org/10.1159/000356513.

Lau JCM, Linsenmeier RA. Oxygen consumption and distribution in the Long-Evans rat retina. Exp. Eye Res. 2012; 102:50-58. http://dx.doi.org/10.1016/j.exer.2012.07.004. [PubMed: 22828049] 
Lengyel I, Tufail A, Hosaini HA, Luthert P, Bird AC, Jeffery G. Association of drusen deposition with choroidal intercapillary pillars in the aging human eye. Investig. Ophthalmol. Vis. Sci. 2004; 45:2886-2892. http://dx.doi.org/10.1167/iovs.03-1083. [PubMed: 15326099]

Li C, Fitzgerald MEC, Ledoux MS, Gong S, Ryan P, Del Mar N, Reiner A. Projections from the hypothalamic paraventricular nucleus and the nucleus of the solitary tract to prechoroidal neurons in the superior salivatory nucleus: pathways controlling rodent choroidal blood flow. Brain Res. 2010; 1358:123-139. http://dx.doi.org/10.1016/j.brainres.2010.08.065. [PubMed: 20801105]

Li C-M, Chung BH, Presley JB, Malek G, Zhang X, Dashti N, Li L, Chen J, Bradley K, Kruth HS, Curcio CA. Lipoprotein-like particles and cholesteryl esters in human Bruch's membrane: initial characterization. Investig. Ophthalmol. Vis. Sci. 2005a; 46:2576-2586. http://dx.doi.org/10.1167/ iovs.05-0034. [PubMed: 15980251]

Li C-M, Presley JB, Zhang X, Dashti N, Chung BH, Medeiros NE, Guidry C, Curcio CA. Retina expresses microsomal triglyceride transfer protein: implications for age-related maculopathy. J. Lipid Res. 2005b; 46:628-640. http://dx.doi.org/10.1194/jlr.M400428-JLR200. [PubMed: 15654125]

Lindblad AS, Lloyd PC, Clemons TE, Gensler GR, Ferris FL, Klein ML, Armstrong JR, Age-Related Eye Disease Study Research Group. Change in area of geographic atrophy in the Age-Related Eye Disease Study: AREDS report number 26. Arch. Ophthalmol. 2009; 127:1168-1174. http:// dx.doi.org/10.1001/archophthalmol.2009.198. [PubMed: 19752426]

Linsenmeier RA. Effects of light and darkness on oxygen distribution and consumption in the cat retina. J. Gen. Physiol. 1986; 88:521-542. [PubMed: 3783124]

Linsenmeier RA, Braun RD. Oxygen distribution and consumption in the cat retina during normoxia and hypoxemia. J. Gen. Physiol. 1992; 99:177-197. [PubMed: 1613482]

Linsenmeier RA, Padnick-Silver L. Metabolic dependence of photoreceptors on the choroid in the normal and detached retina. Investig. Ophthalmol. Vis. Sci. 2000; 41:3117-3123. [PubMed: 10967072]

Lipo E, Cashman SM, Kumar-Singh R. Aurintricarboxylic acid inhibits complement activation, membrane attack complex, and choroidal neovascularization in a model of macular degeneration. Investig. Ophthalmol. Vis. Sci. 2013; 54:7107-7114. http://dx.doi.org/10.1167/iovs.13-12923. [PubMed: 24106121]

Liu A, Chang J, Lin Y, Shen Z, Bernstein PS. Long-chain and very long-chain polyunsaturated fatty acids in ocular aging and age-related macular degeneration. J. Lipid Res. 2010; 51:3217-3229. http://dx.doi.org/10.1194/jlr.M007518. [PubMed: 20688753]

Liu A, Terry R, Lin Y, Nelson K, Bernstein PS. Comprehensive and sensitive quantification of longchain and very long-chain polyunsaturated fatty acids in small samples of human and mouse retina. J. Chromatogr. A. 2013; 1307:191-200. http://dx.doi.org/10.1016/j.chroma.2013.07.103. [PubMed: 23938082]

Liu B, Wei L, Meyerle C, Tuo J, Sen HN, Li Z, Chakrabarty S, Agrón E, Chan C-C, Klein ML, Chew E, Ferris F, Nussenblatt RB. Complement component C5a promotes expression of IL-22 and IL-17 from human T cells and its implication in age-related macular degeneration. J. Transl. Med. 2011; 9:1-12. http://dx.doi.org/10.1186/1479-5876-9-111. [PubMed: 21762495]

Lotery AJ, Munier FL, Fishman GA, Weleber RG, Jacobson SG, Affatigato LM, Nichols BE, Schorderet DF, Sheffield VC, Stone EM. Allelic variation in the VMD2 gene in best disease and age-related macular degeneration. Investig. Ophthalmol. Vis. Sci. 2000; 41:1291-1296. [PubMed: 10798642]

Lozanoska-Ochser B, Peakman M. Level of major histocompatibility complex class I expression on endothelium in non-obese diabetic mice influences CD8 T cell adhesion and migration. Clin. Exp. Immunol. 2009; 157:119-127. http://dx.doi.org/10.1111/j.1365-2249.2009.03940.x. [PubMed: 19659777]

Lutty GA, Hasegawa T, Baba T, Grebe R, Bhutto I, McLeod DS. Development of the human choriocapillaris. Eye. 2010; 24:408-415. http://dx.doi.org/10.1038/eye.2009.318. [PubMed: 20075975]

Lutty GA, McLeod DS. Phosphatase enzyme histochemistry for studying vascular hierarchy, pathology, and endothelial cell dysfunction in retina and choroid. Vis. Res. 2005; 45:3504-3511. http://dx.doi.org/10.1016/j.visres.2005.08.022. [PubMed: 16213000] 
Macular Photocoagulation Study Group. Argon laser photocoagulation for senile macular degeneration. Results of a randomized clinical trial. Arch. Ophthalmol. 1982; 100:912-918. [PubMed: 7046707]

Macular Photocoagulation Study Group. Laser photocoagulation of subfoveal neovascular lesions of age-related macular degeneration. Updated findings from two clinical trials. Arch. Ophthalmol. 1993; 111:1200-1209. [PubMed: 7689827]

Malek G, Johnson LV, Mace BE, Saloupis P, Schmechel DE, Rickman DW, Toth CA, Sullivan PM, Bowes Rickman C. Apolipoprotein E allele-dependent pathogenesis: a model for age-related retinal degeneration. Proc. Natl. Acad. Sci. U. S. A. 2005; 102:11900-11905. http://dx.doi.org/ 10.1073/pnas.0503015102. [PubMed: 16079201]

Maller J, George S, Purcell S, Fagerness J, Altshuler D, Daly MJ, Seddon JM. Common variation in three genes, including a noncoding variant in $\mathrm{CFH}$, strongly influences risk of age-related macular degeneration. Nat. Genet. 2006; 38:1055-1059. http://dx.doi.org/10.1038/ng1873. [PubMed: 16936732]

Mancini MA, Frank RN, Keirn RJ, Kennedy A, Khoury JK. Does the retinal pigment epithelium polarize the choriocapillaris? Investig. Ophthalmol. Vis. Sci. 1986; 27:336-345. [PubMed: 3949463]

Mangione CM, Gutierrez PR, Lowe G, Orav EJ, Seddon JM. Influence of age-related maculopathy on visual functioning and health-related quality of life. Am. J. Ophthalmol. 1999; 128:45-53. [PubMed: 10482093]

Mao M, Thedens DR, Chang B, Harris BS, Zheng QY, Johnson KR, Donahue LR, Anderson MG. The podosomal-adaptor protein SH3PXD2B is essential for normal postnatal development. Mamm. Genome. 2009; 20:462-475. http://dx.doi.org/10.1007/s00335-009-9210-9. [PubMed: 19669234]

May CA, Lütjen-Drecoll E. Choroidal ganglion cells in prenatal, young, and middle-aged human donor eyes. Curr. Eye Res. 2005; 30:667-672. http://dx.doi.org/10.1080/02713680590968231. [PubMed: 16109647]

May CA, Neuhuber W, Lütjen-Drecoll E. Immunohistochemical classification and functional morphology of human choroidal ganglion cells. Investig. Ophthalmol. Vis. Sci. 2004; 45:361367. [PubMed: 14744873]

McGwin G, Hall TA, Xie A, Owsley C. The relation between C reactive protein and age related macular degeneration in the Cardiovascular Health Study. Br. J. Ophthalmol. 2005; 89:11661170. http://dx.doi.org/10.1136/bjo.2005.067397. [PubMed: 16113374]

McLeod DS, Grebe R, Bhutto I, Merges C, Baba T, Lutty GA. Relationship between RPE and choriocapillaris in age-related macular degeneration. Investig. Ophthalmol. Vis. Sci. 2009; 50:4982-4991. http://dx.doi.org/10.1167/iovs.09-3639. [PubMed: 19357355]

McLeod DS, Lefer DJ, Merges C, Lutty GA. Enhanced expression of intracellular adhesion molecule-1 and P-selectin in the diabetic human retina and choroid. Am. J. Pathol. 1995; 147:642-653. [PubMed: 7545873]

McLeod DS, Lutty GA. High-resolution histologic analysis of the human choroidal vasculature. Investig. Ophthalmol. Vis. Sci. 1994; 35:3799-3811. [PubMed: 7928177]

Melillo D, Sfyroera G, De Santis R, Graziano R, Marino R, Lambris JD, Pinto MR. First identification of a chemotactic receptor in an invertebrate species: structural and functional characterization of Ciona intestinalis C3a receptor. J. Immunol. 2006; 177:4132-4140. [PubMed: 16951378]

Mrejen S, Spaide RF. Optical coherence tomography: imaging of the choroid and beyond. Surv. Ophthalmol. 2013; 58:387-429. http://dx.doi.org/10.1016/j.survophthal.2012.12.001. [PubMed: 23916620]

Mullins RF, Aptsiauri N, Hageman GS. Structure and composition of drusen associated with glomerulonephritis: implications for the role of complement activation in drusen biogenesis. Eye (Lond.). 2001; 15:390-395. http://dx.doi.org/10.1038/eye.2001.142. [PubMed: 11450763]

Mullins RF, Dewald AD, Streb LM, Wang K, Kuehn MH, Stone EM. Elevated membrane attack complex in human choroid with high risk complement factor H genotypes. Exp. Eye Res. 2011a; 93:3. http://dx.doi.org/10.1016/j.exer.2011.06.015.

Mullins RF, Grassi MA, Skeie JM. Glycoconjugates of choroidal neovascular membranes in agerelated macular degeneration. Mol. Vis. 2005; 11:509-517. [PubMed: 16052166] 
Mullins RF, Johnson MN, Faidley EA, Skeie JM, Huang J. Choriocapillaris vascular dropout related to density of drusen in human eyes with early age-related macular degeneration. Investig. Ophthalmol. Vis. Sci. 2011b; 52:1606-1612. http://dx.doi.org/10.1167/iovs.10-6476. [PubMed: 21398287]

Mullins RF, Russell SR, Anderson DH, Hageman GS. Drusen associated with aging and age-related macular degeneration contain proteins common to extracellular deposits associated with atherosclerosis, elastosis, amyloidosis, and dense deposit disease. FASEB J. 2000; 14:835-846. [PubMed: 10783137]

Mullins RF, Skeie JM, Malone EA, Kuehn MH. Macular and peripheral distribution of ICAM-1 in the human choriocapillaris and retina. Mol. Vis. 2006; 12:224-235. [PubMed: 16604055]

Mullins RF, Schoo DP, Sohn EH, Flamme-Wiese MJ, Workamelahu G, Johnston RM, Wang K, Tucker BA, Stone EM. The membrane attack complex in aging human choriocapillaris: relationship to macular degeneration and choroidal thinning. Am. J. Pathol. 2014; 184 http:// dx.doi.org/10.1016/j.ajpath.2014.07.017.

Murinello S, Mullins RF, Lotery AJ, Perry VH, Teeling JL. Fc $\gamma$ receptor upregulation is associated with immune complex inflammation in the mouse retina and early age-related macular degeneration. Investig. Ophthalmol. Vis. Sci. 2014; 55:247-258. http://dx.doi.org/10.1167/iovs. 13-11821. [PubMed: 24334446]

Newman AM, Gallo NB, Hancox LS, Miller NJ, Radeke CM, Maloney MA, Cooper JB, Hageman GS, Anderson DH, Johnson LV, Radeke MJ. Systems-level analysis of age-related macular degeneration reveals global biomarkers and phenotype-specific functional networks. Genome Med. 2012; 4:16. http://dx.doi.org/10.1186/gm315. [PubMed: 22364233]

Nickla DL, Wallman J. The multifunctional choroid. Prog. Retin. Eye Res. 2010; 29:144-168. http:// dx.doi.org/10.1016/j.preteyeres.2009.12.002. [PubMed: 20044062]

Nielsen JS, McNagny KM. Novel functions of the CD34 family. J. Cell Sci. 2008; 121:3683-3692. http://dx.doi.org/10.1242/jcs.037507. [PubMed: 18987355]

Niemeijer M, van Ginneken B, Russell SR, Suttorp-Schulten MSA, Abràmoff MD. Automated detection and differentiation of drusen, exudates, and cotton-wool spots in digital color fundus photographs for diabetic retinopathy diagnosis. Investig. Ophthalmol. Vis. Sci. 2007; 48:2260 2267. http://dx.doi.org/10.1167/iovs.06-0996. [PubMed: 17460289]

Nishiguchi KM, Yasuma TR, Tomida D, Nakamura M, Ishikawa K, Kikuchi M, Ohmi Y, Niwa T, Hamajima N, Furukawa K, Terasaki H. C9-R95X polymorphism in patients with neovascular age-related macular degeneration. Investig. Ophthalmol. Vis. Sci. 2012; 53:508-512. http:// dx.doi.org/10.1167/iovs.11-8425. [PubMed: 22190594]

Nonaka M, Kimura A. Genomic view of the evolution of the complement system. Immunogenetics. 2006; 58:701-713. http://dx.doi.org/10.1007/s00251-006-0142-1. [PubMed: 16896831]

Nonaka M, Yoshizaki F. Evolution of the complement system. Mol. Immunol. 2004; 40:897-902. [PubMed: 14698228]

Nozaki M, Raisler BJ, Sakurai E, Sarma JV, Barnum SR, Lambris JD, Chen Y, Zhang K, Ambati BK, Baffi JZ, Ambati J. Drusen complement components C3a and C5a promote choroidal neovascularization. Proc. Natl. Acad. Sci. U. S. A. 2006; 103:2328-2333. http://dx.doi.org/ 10.1073/pnas.0408835103. [PubMed: 16452172]

Okemefuna AI, Nan R, Miller A, Gor J, Perkins SJ. Complement factor H binds at two independent sites to C-reactive protein in acute phase concentrations. J. Biol. Chem. 2010; 285:1053-1065. http://dx.doi.org/10.1074/jbc.M109.044529. [PubMed: 19850925]

Ormsby RJ, Ranganathan S, Tong JC, Griggs KM, Dimasi DP, Hewitt AW, Burdon KP, Craig JE, Hoh J, Gordon DL. Functional and structural implications of the complement factor $\mathrm{H} \mathrm{Y} 402 \mathrm{H}$ polymorphism associated with age-related macular degeneration. Investig. Ophthalmol. Vis. Sci. 2008; 49:1763-1770. http://dx.doi.org/10.1167/iovs.07-1297. [PubMed: 18263814]

Otsuji T, McLeod DS, Hansen B, Lutty G. Immunohistochemical staining and morphometric analysis of the monkey choroidal vasculature. Exp. Eye Res. 2002; 75:201-208. [PubMed: 12137765]

Owsley C, Huisingh C, Jackson GR, Curcio CA, Szalai AJ, Dashti N, Clark M, Rookard K, McCrory MA, Wright TT, Callahan MA, Kline LB, Witherspoon CD, McGwin G. Associations between abnormal rod-mediated dark adaptation and health and functioning in older adults with normal

Prog Retin Eye Res. Author manuscript; available in PMC 2016 March 01. 
macular health. Investig. Ophthalmol. Vis. Sci. 2014; 55:4776-4789. http://dx.doi.org/10.1167/ iovs.14-14502. [PubMed: 24854857]

Owsley C, McGwin G, Jackson GR, Kallies K, Clark M. Cone- and rod-mediated dark adaptation impairment in age-related maculopathy. Ophthalmology. 2007; 114:1728-1735. http://dx.doi.org/ 10.1016/j.ophtha.2006.12.023. [PubMed: 17822978]

Parham P, Norman PJ, Abi-Rached L, Hilton HG, Guethlein LA. Review: immunogenetics of human placentation. Placenta. 2012; 33(Suppl. 1):S71-S80. http://dx.doi.org/10.1016/j.placenta. 2011.11.020. [PubMed: 22177321]

Parver LM, Auker C, Carpenter DO. Choroidal blood flow as a heat dissipating mechanism in the macula. Am. J. Ophthalmol. 1980; 89:641-646. [PubMed: 6769334]

Parver LM. Temperature modulating action of choroidal blood flow. Eye (Lond.). 1991; 5(Pt 2):181185. http://dx.doi.org/10.1038/eye.1991.32. [PubMed: 2070878]

Pasceri V, Willerson JT, Yeh ET. Direct proinflammatory effect of C-reactive protein on human endothelial cells. Circulation. 2000; 102:2165-2168. [PubMed: 11056086]

Pauleikhoff D, Spital G, Radermacher M, Brumm GA, Lommatzsch A, Bird AC. A fluorescein and indocyanine green angiographic study of choriocapillaris in age-related macular disease. Arch. Ophthalmol. 1999; 117:1353-1358. [PubMed: 10532443]

Pavlov N, Frendo J-L, Guibourdenche J, Degrelle SA, Evain-Brion D, Badet J. Angiogenin expression during early human placental development; association with blood vessel formation. Biomed. Res. Int. 2014; 2014:781632. http://dx.doi.org/10.1155/2014/781632. [PubMed: 25093183]

Penfold PL, Killingsworth MC, Sarks SH. Senile macular degeneration: the involvement of immunocompetent cells. Graefes Arch. Clin. Exp. Ophthalmol. 1985; 223:69-76. [PubMed: 2408968]

Penfold PL, Killingsworth MC, Sarks SH. Senile macular degeneration. The involvement of giant cells in atrophy of the retinal pigment epithelium. Investig. Ophthalmol. Vis. Sci. 1986; 27:364-371. [PubMed: 3949464]

Pennesi ME, Neuringer M, Courtney RJ. Animal models of age related macular degeneration. Mol. Asp. Med. 2012; 33:487-509. http://dx.doi.org/10.1016/j.mam.2012.06.003.

Pikuleva IA, Curcio CA. Cholesterol in the retina: the best is yet to come. Prog. Retin. Eye Res. 2014; 41:64-89. http://dx.doi.org/10.1016/j.preteyeres.2014.03.002. [PubMed: 24704580]

Pinto MR, Melillo D, Giacomelli S, Sfyroera G, Lambris JD. Ancient origin of the complement system: emerging invertebrate models. Adv. Exp. Med. Biol. 2007; 598:372-388. http:// dx.doi.org/10.1007/978-0-387-71767-8_26. [PubMed: 17892225]

Quellec G, Russell SR, Scheetz TE, Stone EM, Abr amoff MD. Computational quantification of complex fundus phenotypes in age-related macular degeneration and Stargardt disease. Investig. Ophthalmol. Vis. Sci. 2011a; 52:2976-2981. http://dx.doi.org/10.1167/iovs.10-6232. [PubMed: 21310908]

Quellec G, Russell SR, Seddon JM, Reynolds R, Scheetz T, Mahajan VB, Stone EM, Abràmoff MD. Automated discovery and quantification of image-based complex phenotypes: a twin study of drusen phenotypes in age-related macular degeneration. Investig. Ophthalmol. Vis. Sci. 2011b; 52:9195-9206. http://dx.doi.org/10.1167/iovs.10-6793. [PubMed: 22039249]

Ramrattan RS, van der Schaft TL, Mooy CM, de Bruijn WC, Mulder PG, de Jong PT. Morphometric analysis of Bruch's membrane, the choriocapillaris, and the choroid in aging. Investig. Ophthalmol. Vis. Sci. 1994; 35:2857-2864. [PubMed: 8188481]

Richardson AJ, Islam FMA, Aung KZ, Guymer RH, Baird PN. An inter-genic region between the tagSNP rs3793917 and rs11200638 in the HTRA1 gene indicates association with age-related macular degeneration. Investig. Ophthalmol. Vis. Sci. 2010; 51:4932-4936. http://dx.doi.org/ 10.1167/iovs.09-5114. [PubMed: 20445115]

Rifai N, Ridker PM. High-sensitivity C-reactive protein: a novel and promising marker of coronary heart disease. Clin. Chem. 2001; 47:403-411. [PubMed: 11238289]

Rivera A. Hypothetical LOC387715 is a second major susceptibility gene for age-related macular degeneration, contributing independently of complement factor $\mathrm{H}$ to disease risk. Hum. Mol. Genet. 2005; 14:3227-3236. http://dx.doi.org/10.1093/hmg/ddi353. [PubMed: 16174643] 
Rohrer B, Coughlin B, Bandyopadhyay M, Holers VM. Systemic human CR2-targeted complement alternative pathway inhibitor ameliorates mouse laser-induced choroidal neovascularization. J. Ocul. Pharmacol. Ther. 2012; 28:402-409. http://dx.doi.org/10.1089/jop.2011.0212. [PubMed: 22309197]

Rosenfeld PJ, Brown DM, Heier JS, Boyer DS, Kaiser PK, Chung CY, Kim RY, MARINA Study Group. Ranibizumab for neovascular age-related macular degeneration. N. Engl. J. Med. 2006; 355:1419-1431. http://dx.doi.org/10.1056/NEJMoa054481. [PubMed: 17021318]

Rosenfeld PJ, Moshfeghi AA, Puliafito CA. Optical coherence tomography findings after an intravitreal injection of bevacizumab (avastin) for neovascular age-related macular degeneration. Ophthalmic Surg. Lasers Imaging. 2005; 36:331-335. [PubMed: 16156152]

Ruberti JW, Curcio CA, Millican CL, Menco BPM, Huang J-D, Johnson M. Quick-freeze/deep-etch visualization of age-related lipid accumulation in Bruch's membrane. Investig. Ophthalmol. Vis. Sci. 2003; 44:1753-1759. [PubMed: 12657618]

Rus H, Cudrici C, David S, Niculescu F. The complement system in central nervous system diseases. Autoimmunity. 2006; 39:395-402. http://dx.doi.org/10.1080/08916930600739605. [PubMed: 16923539]

Russell SR, Mullins RF, Schneider BL, Hageman GS. Location, substructure, and composition of basal laminar drusen compared with drusen associated with aging and age-related macular degeneration. Am. J. Ophthalmol. 2000; 129:205-214. [PubMed: 10682974]

Rutar M, Valter K, Natoli R, Provis JM. Synthesis and propagation of complement C3 by microglia/ monocytes in the aging retina. PLoS One. 2014; 9:e93343. http://dx.doi.org/10.1371/ journal.pone.0093343. [PubMed: 24705166]

Saint-Geniez M, Kurihara T, Sekiyama E, Maldonado AE, D'Amore PA. An essential role for RPEderived soluble VEGF in the maintenance of the choriocapillaris. Proc. Natl. Acad. Sci. U. S. A. 2009; 106:18751-18756. http://dx.doi.org/10.1073/pnas.0905010106. [PubMed: 19841260]

Saint-Geniez M, Maldonado AE, D'Amore PA. VEGF expression and receptor activation in the choroid during development and in the adult. Investig. Ophthalmol. Vis. Sci. 2006; 47:31353142. http://dx.doi.org/10.1167/iovs.05-1229. [PubMed: 16799060]

Sakurai E, Taguchi H, Anand A, Ambati BK, Gragoudas ES, Miller JW, Adamis AP, Ambati J. Targeted disruption of the CD18 or ICAM-1 gene inhibits choroidal neovascularization. Investig. Ophthalmol. Vis. Sci. 2003; 44:2743-2749. [PubMed: 12766082]

SanGiovanni JP, Chew EY, Clemons TE, Davis MD, Ferris FL, Gensler GR, Kurinij N, Lindblad AS, Milton RC, Seddon JM, Sperduto RD, Age-Related Eye Disease Study Research Group, AgeRelated Eye Disease Study Research Group. The relationship of dietary lipid intake and agerelated macular degeneration in a case-control study: AREDS report no. 20. Arch. Ophthalmol. 2007; 125:671-679. http://dx.doi.org/10.1001/archopht.125.5.671. [PubMed: 17502507]

Sarks JP, Sarks SH, Killingsworth MC. Evolution of geographic atrophy of the retinal pigment epithelium. Eye (Lond.). 1988; 2(Pt 5):552-577. http://dx.doi.org/10.1038/eye.1988.106. [PubMed: 2476333]

Sarks S, Cherepanoff S, Killingsworth M, Sarks J. Relationship of Basal laminar deposit and membranous debris to the clinical presentation of early age-related macular degeneration. Investig. Ophthalmol. Vis. Sci. 2007; 48:968-977. http://dx.doi.org/10.1167/iovs.06-0443. [PubMed: 17325134]

Sarks SH. Ageing and degeneration in the macular region: a clinico-pathological study. Br. J. Ophthalmol. 1976; 60:324-341. [PubMed: 952802]

Sarks SH. Shimizu K, Oosterhuis JA. Changes in the region of the choriocapillaris in aging and degeneration. Proc. XXIII Int. Congr., Kyoto. 19781979:228-232.

Sarks SH, Arnold JJ, Killingsworth MC, Sarks JP. Early drusen formation in the normal and aging eye and their relation to age related maculopathy: a clinicopathological study. Br. J. Ophthalmol. 1999; 83:358-368. [PubMed: 10365048]

Schmidt S, Hauser MA, Scott WK, Postel EA, Agarwal A, Gallins P, Wong F, Chen YS, Spencer K, Schnetz-Boutaud N, Haines JL, Pericak-Vance MA. Cigarette smoking strongly modifies the association of LOC387715 and age-related macular degeneration. Am. J. Hum. Genet. 2006; 78:852-864. http://dx.doi.org/10.1086/503822. [PubMed: 16642439] 
Scholl HPN, Charbel Issa P, Walier M, Janzer S, Pollok-Kopp B, Börncke F, Fritsche LG, Chong NV, Fimmers R, Wienker T, Holz FG, Weber BHF, Oppermann M. Systemic complement activation in age-related macular degeneration. PLoS One. 2008; 3:e2593. http://dx.doi.org/10.1371/ journal.pone.0002593. [PubMed: 18596911]

Schrödl F, Brehmer A, Neuhuber WL, Nickla D. The autonomic facial nerve pathway in birds: a tracing study in chickens. Investig. Ophthalmol. Vis. Sci. 2006; 47:3225-3233. http://dx.doi.org/ 10.1167/iovs.05-1279. [PubMed: 16877385]

Schwartz DM, Fingler J, Kim DY, Zawadzki RJ, Morse LS, Park SS, Fraser SE, Werner JS. Phasevariance optical coherence tomography: a technique for noninvasive angiography. Ophthalmology. 2014; 121:180-187. http://dx.doi.org/10.1016/j.ophtha.2013.09.002. [PubMed: 24156929]

Schwartz SG, Agarwal A, Kovach JL, Gallins PJ, Cade W, Postel EA, Wang G, Ayala-Haedo J, Spencer KM, Haines JL, Pericak-Vance MA, Scott WK. The ARMS2 A69S variant and bilateral advanced age-related macular degeneration. Retina. 2012; 32:1486-1491. http://dx.doi.org/ 10.1097/IAE.0b013-318240a540. [PubMed: 22481475]

Schwedler SB, Filep JG, Galle J, Wanner C, Potempa LA. C-reactive protein: a family of proteins to regulate cardiovascular function. Am. J. Kidney Dis. 2006; 47:212-222. http://dx.doi.org/ 10.1053/j.ajkd.2005.10.028. [PubMed: 16431250]

Seddon JM, Afshari MA, Sharma S, Bernstein PS, Chong S, Hutchinson A, Petrukhin K, Allikmets R. Assessment of mutations in the best macular dystrophy (VMD2) gene in patients with adult-onset foveomacular vitelliform dystrophy, age-related maculopathy, and bull's-eye maculopathy. Ophthalmology. 2001a; 108:2060-2067. [PubMed: 11713080]

Seddon JM, Ajani UA, Sperduto RD, Hiller R, Blair N, Burton TC, Farber MD, Gragoudas ES, Haller J, Miller DT. Dietary carotenoids, vitamins A, C, and E, and advanced age-related macular degeneration. Eye Disease Case-Control Study Group. JAMA. 1994; 272:1413-1420. [PubMed: 7933422]

Seddon JM, Cote J, Rosner B. Progression of age-related macular degeneration: association with dietary fat, transunsaturated fat, nuts, and fish intake. Arch. Ophthalmol. 2003; 121:1728-1737. http://dx.doi.org/10.1001/archopht.121.12.1728. [PubMed: 14662593]

Seddon JM, Gensler G, Milton RC, Klein ML, Rifai N. Association between C-reactive protein and age-related macular degeneration. JAMA. 2004; 291:704-710. http://dx.doi.org/10.1001/jama. 291.6.704. [PubMed: 14871913]

Seddon JM, Gensler G, Rosner B. C-reactive protein and CFH, ARMS2/HTRA1 gene variants are independently associated with risk of macular degeneration. Ophthalmology. 2010; 117:1560 1566. http://dx.doi.org/10.1016/j.ophtha.2009.11.020. [PubMed: 20346514]

Seddon JM, George S, Rosner B, Rifai N. Progression of age-related macular degeneration: prospective assessment of C-reactive protein, inter-leukin 6, and other cardiovascular biomarkers. Arch. Ophthalmol. 2005; 123:774-782. http://dx.doi.org/10.1001/archopht. 123.6.774. [PubMed: 15955978]

Seddon JM, Ramrattan RS, Willett WC, van der Schaft TL, Speizer FE, Mooy CM, Hankinson SE, de Bruijn WC, Mulder PG, de Jong PT. A prospective study of cigarette smoking and age-related macular degeneration in women. JAMA. 1996; 276:1141-1146. [PubMed: 8827966]

Seddon JM, Reynolds R, Yu Y, Rosner B. Three new genetic loci (R1210C in CFH, variants in COL8A1 and RAD51B) are independently related to progression to advanced macular degeneration. PLoS One. 2014; 9:e87047. http://dx.doi.org/10.1371/journal.pone.0087047. [PubMed: 24498017]

Seddon JM, Stevens B, Rosner B, Allen NJ, Sperduto RD, Vazquez LE, Yannuzzi L, Howell GR, Haller JA, Christopherson KS, Blair NP, Nouri N, Willett W, Micheva KD, Mehalow AK, Huberman AD, Stafford B, Sher A, Litke AM, Lambris JD, Smith SJ, John SWM, Barres BA. Dietary fat and risk for advanced age-related macular degeneration. Arch. Ophthalmol. 2001b; 119:1191-1199. [PubMed: 11483088]

Seddon, JM.; Yu, Y.; Miller, EC.; Reynolds, R.; Tan, PL.; Gowrisankar, S.; Goldstein, JI.; Triebwasser, M.; Anderson, HE.; Zerbib, J.; Kavanagh, D.; Souied, E.; Katsanis, N.; Daly, MJ.; Atkinson, JP.; Raychaudhuri, S. Rare variants in CFI, C3 and C9 are associated with high risk of 
advanced age-related macular degeneration.. Nat. Genet. 2013. http://dx.doi.org/10.1038/ng. 2741.

Seitsonen SP, Onkamo P, Peng G, Xiong M, Tommila PV, Ranta PH, Holopainen JM, Moilanen JA, Palosaari T, Kaarniranta K, Meri S, Immonen IR, Järvelä IE. Multifactor effects and evidence of potential interaction between complement factor H Y402H and LOC387715 A69S in age-related macular degeneration. PLoS One. 2008; 3:e3833. http://dx.doi.org/10.1371/journal.pone. 0003833. [PubMed: 19048105]

Sekine H, Takahashi M, Iwaki D, Fujita T. The role of MASP-1/3 in complement activation. Adv. Exp. Med. Biol. 2013; 735:41-53. [PubMed: 23402018]

Sekiyama E, Saint-Geniez M, Yoneda K, Hisatomi T, Nakao S, Walshe TE, Maruyama K, HafeziMoghadam A, Miller JW, Kinoshita S, D'Amore PA. Heat treatment of retinal pigment epithelium induces production of elastic lamina components and antiangiogenic activity. FASEB J. 2012; 26:567-575. http://dx.doi.org/10.1096/fj.11-184127. [PubMed: 22067481]

Seth A, Cui J, To E, Kwee M, Matsubara J. Complement-associated deposits in the human retina. Investig. Ophthalmol. Vis. Sci. 2008; 49:743-750. http://dx.doi.org/10.1167/iovs.07-1072. [PubMed: 18235023]

Shaw PX, Zhang L, Zhang M, Du H, Zhao L, Lee C, Grob S, Lim SL, Hughes G, Lee J, Bedell M, Nelson MH, Lu F, Krupa M, Luo J, Ouyang H, Tu Z, Su Z, Zhu J, Wei X, Feng Z, Duan Y, Yang Z, Ferreyra H, Bartsch D-U, Kozak I, Zhang L, Lin F, Sun H, Feng H, Zhang K. Complement factor $\mathrm{H}$ genotypes impact risk of age-related macular degeneration by interaction with oxidized phospholipids. Proc. Natl. Acad. Sci. U. S. A. 2012; 109:13757-13762. http://dx.doi.org/ 10.1073/pnas.1121309109. [PubMed: 22875704]

Skeie JM, Fingert JH, Russell SR, Stone EM, Mullins RF. Complement component C5a activates ICAM-1 expression on human choroidal endothelial cells. Investig. Ophthalmol. Vis. Sci. 2010; 51:5336-5342. http://dx.doi.org/10.1167/iovs.10-5322. [PubMed: 20484595]

Skeie JM, Mullins RF. Macrophages in neovascular age-related macular degeneration: friends or foes? Eye. 2009; 23:747-755. http://dx.doi.org/10.1038/eye.2008.206. [PubMed: 18600240]

Skondra D, Papakostas T, Vavvas DG. Enhanced depth imaging optical coherence tomography in agerelated macular degeneration. Semin. Ophthalmol. 2012; 27:209-212. http://dx.doi.org/ 10.3109/08820538.2012.708807. [PubMed: 23163278]

Slakter JS, Yannuzzi LA, Guyer DR, Sorenson JA, Orlock DA. Indocyanine-green angiography. Curr. Opin. Ophthalmol. 1995; 6:25-32. [PubMed: 10151085]

Smailhodzic D, Klaver CC, Klevering BJ, Boon CJ, Groenewoud JM, Kirchhof B, Daha MR, Hollander den AI, Hoyng CB. Risk alleles in CFH and ARMS2 are independently associated with systemic complement activation in age-related macular degeneration. Ophthalmology. 2012; 119:339-346. http://dx.doi.org/10.1016/j.ophtha.2011.07.056. [PubMed: 22133792]

Sobrin L, Reynolds R, Yu Y, Fagerness J, Leveziel N, Bernstein PS, Souied EH, Daly MJ, Seddon JM. ARMS2/HTRA1 locus can confer differential susceptibility to the advanced subtypes of agerelated macular degeneration. Am. J. Ophthalmol. 2011; 151:345-352. e3. http://dx.doi.org/ 10.1016/j.ajo.2010.08.015. [PubMed: 21122828]

Sohn EH, Flamme-Wiese MJ, Whitmore SS, Wang K, Tucker BA, Mullins RF. Loss of CD34 expression in aging muman choriocapillaris endothelial cells. PLoS One. 2014a; 9 http:// dx.doi.org/10.1371/journal.pone.0086538.

Sohn, EH.; Khanna, A.; Tucker, BA.; Abramoff, MD.; Stone, EM.; Mullins, RF. Structural and biochemical analyses of choroidal thickness in human donor eyes.. Investig. Ophthalmol. Vis. Sci. 2014b. http://dx.doi.org/10.1167/iovs.13-13754

Sohn, EH.; Mullins, RF.; Stone, EM. Chapter 42-Macular dystrophies.. In: Ryan, SJ.; Sadda, SR.; Hinton, DR.; Schachat, AP.; Wilkinson, CP.; Wiedemann, P., editors. Retina. fifth ed.. W.B. Saunders; London: 2013. p. 852-890.

Soubrane G, Cruess A, Lotery A, Pauleikhoff D, Monès J, Xu X, Zlateva G, Buggage R, Conlon J, Goss TF. Burden and health care resource utilization in neovascular age-related macular degeneration: findings of a multi-country study. Arch. Ophthalmol. 2007; 125:1249-1254. http:// dx.doi.org/10.1001/archopht.125.9.1249. [PubMed: 17846366]

Prog Retin Eye Res. Author manuscript; available in PMC 2016 March 01. 
Spaide RF. Age-related choroidal atrophy. Am. J. Ophthalmol. 2009; 147:801-810. http://dx.doi.org/ 10.1016/j.ajo.2008.12.010. [PubMed: 19232561]

Spaide RF, Koizumi H, Pozzoni MC, Pozonni MC. Enhanced depth imaging spectral-domain optical coherence tomography. Am. J. Ophthalmol. 2008; 146:496-500. http://dx.doi.org/10.1016/j.ajo. 2008.05.032. [PubMed: 18639219]

Spraul CW, Lang GE, Grossniklaus HE. Morphometric analysis of the choroid, Bruch's membrane, and retinal pigment epithelium in eyes with age-related macular degeneration. Investig. Ophthalmol. Vis. Sci. 1996; 37:2724-2735. [PubMed: 8977488]

Stan RV, Tse D, Deharvengt SJ, Smits NC, Xu Y, Luciano MR, McGarry CL, Buitendijk M, Nemani KV, Elgueta R, Kobayashi T, Shipman SL, Moodie KL, Daghlian CP, Ernst PA, Lee H-K, Suriawinata AA, Schned AR, Longnecker DS, Fiering SN, Noelle RJ, Gimi B, Shworak NW, Carrière $\mathrm{C}$. The diaphragms of fenestrated endothelia: gatekeepers of vascular permeability and blood composition. Dev. Cell. 2012; 23:1203-1218. http://dx.doi.org/10.1016/j.devcel. 2012.11.003. [PubMed: 23237953]

Starita C, Hussain AA, Pagliarini S, Marshall J. Hydrodynamics of ageing Bruch's membrane: implications for macular disease. Exp. Eye Res. 1996; 62:565-572. http://dx.doi.org/10.1006/ exer.1996.0066. [PubMed: 8759524]

Staurenghi G, Flower RW. Clinical observations supporting a theoretical model of choriocapillaris blood flow in treatment of choroidal neovascularization associated with age-related macular degeneration. Am. J. Ophthalmol. 2002; 133:801-808. [PubMed: 12036672]

Stevens B, Allen NJ, Vazquez LE, Howell GR, Christopherson KS, Nouri N, Micheva KD, Mehalow AK, Huberman AD, Stafford B, Sher A, Litke AM, Lambris JD, Smith SJ, John SWM, Barres BA. The classical complement cascade mediates CNS synapse elimination. Cell. 2007; 131:1164-1178. http://dx.doi.org/10.1016/j.cell.2007.10.036. [PubMed: 18083105]

Stewart EA, Samaranayake GJ, Browning AC, Hopkinson A, Amoaku WM. Comparison of choroidal and retinal endothelial cells: characteristics and response to VEGF isoforms and anti-VEGF treatments. Exp. Eye Res. 2011; 93:761-766. http://dx.doi.org/10.1016/j.exer.2011.09.010. [PubMed: 21970900]

Stitt AW, O'Neill CL, O'Doherty MT, Archer DB, Gardiner TA, Medina RJ. Vascular stem cells and ischaemic retinopathies. Prog. Retin. Eye Res. 2011; 30:149-166. http://dx.doi.org/10.1016/ j.preteyeres.2011.02.001. [PubMed: 21352947]

Stone EM, Braun TA, Russell SR, Kuehn MH, Lotery AJ, Moore PA, Eastman CG, Casavant TL, Sheffield VC. Missense variations in the fibulin 5 gene and age-related macular degeneration. N. Engl. J. Med. 2004; 351:346-353. http://dx.doi.org/10.1056/NEJMoa040833. [PubMed: 15269314]

Sugita A, Hamasaki M, Higashi R. Regional difference in fenestration of choroidal capillaries in Japanese monkey eye. Jpn. J. Ophthalmol. 1982; 26:47-52. [PubMed: 7109332]

Takano T, Elimam H, Cybulsky AV. Complement-mediated cellular injury. Semin. Nephrol. 2013; 33:586-601. http://dx.doi.org/10.1016/j.semnephrol.2013.08.009. [PubMed: 24161043]

Taubes G. Cardiovascular disease. Does inflammation cut to the heart of the matter? Science. 2002; 296:242-245. http://dx.doi.org/10.1126/science.296.5566.242. [PubMed: 11951014]

Thompson BR, Lobo S, Bernlohr DA. Fatty acid flux in adipocytes: the in"s and out"s of fat cell lipid trafficking. Mol. Cell. Endocrinol. 2010; 318:24-33. http://dx.doi.org/10.1016/j.mce. 2009.08.015. [PubMed: 19720110]

Thurman JM, Holers VM. The central role of the alternative complement pathway in human disease. J. Immunol. 2006; 176:1305-1310. [PubMed: 16424154]

Tillett WS, Frances T Jr. Serological reactions in pneumonia with a non-protein somatic fraction of pneumococcus. J. Exp. Med. 1930; 52:561-571. [PubMed: 19869788]

Tilton RG, Miller EJ, Kilo C, Williamson JR. Pericyte form and distribution in rat retinal and uveal capillaries. Investig. Ophthalmol. Vis. Sci. 1985; 26:68-73. [PubMed: 3967956]

Tozer K, Roller AB, Chong LP, Sadda S, Folk JC, Mahajan VB, Russell SR, Boldt HC, Sohn EH. Combination therapy for neovascular age-related macular degeneration refractory to antivascular endothelial growth factor agents. Ophthalmology. 2013; 120:2029-2034. http:// dx.doi.org/10.1016/j.ophtha.2013.03.016. [PubMed: 23714319] 
Treatment of Age-related Macular Degeneration With Photodynamic Therapy (TAP) Study Group. Photodynamic therapy of subfoveal choroidal neovascularization in age-related macular degeneration with verteporfin: one-year results of 2 randomized clinical trialseTAP report 1. Arch. Ophthalmol. 1999; 117:1329-1345. [PubMed: 10532441]

Tserentsoodol N, Sztein J, Campos M, Gordiyenko NV. Uptake of cholesterol by the retina occurs primarily via a low density lipoprotein receptor-mediated process. Mol. Vis.. 2006

Tucker BA, Mullins RF, Stone EM. Stem cells for investigation and treatment of inherited retinal disease. Hum. Mol. Genet. 2014; 23:R9-R16. http://dx.doi.org/10.1093/hmg/ddu124. [PubMed: 24647603]

Tuo J, Ross RJ, Reed GF, Yan Q, Wang JJ, Bojanowski CM, Chew EY, Feng X, Olsen TW, Ferris FL, Mitchell P, Chan C-C. The HtrA1 promoter polymorphism, smoking, and age-related macular degeneration in multiple case-control samples. Ophthalmology. 2008; 115:1891-1898. http:// dx.doi.org/10.1016/j.ophtha.2008.05.021. [PubMed: 18718667]

Tymms MJ. Sorsby's fundus dystrophy: what does TIMP3 tell us about general mechanisms underlying macular degeneration? Clin. Exp. Optom. 1999; 82:124-129. [PubMed: 12482286]

van Landingham SW, Massof RW, Chan E, Friedman DS, Ramulu PY. Fear of falling in age-related macular degeneration. BMC Ophthalmol. 2014; 14:10. http://dx.doi.org/ 10.1186/1471-2415-14-10. [PubMed: 24472499]

Verteporfin In Photodynamic Therapy Study Group. Verteporfin therapy of subfoveal choroidal neovascularization in age-related macular degeneration: two-year results of a randomized clinical trial including lesions with occult with no classic choroidal neovascularizationeverteporfin in photodynamic therapy report 2. Am. J. Ophthalmol. 2001; 131:541-560. [PubMed: 11336929]

Vingerling JR, Vingerling JR, Hofman A, Hofman A, Grobbee DE, Grobbee DE, de Jong PT, de Jong PT. Age-related macular degeneration and smoking. Rotterdam Study. Arch. Ophthalmol. 1996; 114:1193-1196.

Vogt SD, Barnum SR, Curcio CA, Read RW. Distribution of complement anaphylatoxin receptors and membrane-bound regulators in normal human retina. Exp. Eye Res. 2006; 83:834-840. http:// dx.doi.org/10.1016/j.exer.2006.04.002. [PubMed: 16764856]

Vogt SD, Curcio CA, Wang L, Li C-M, McGwin G Jr. Medeiros NE, Philp NJ, Kimble JA, Read RW. Retinal pigment epithelial expression of complement regulator CD46 is altered early in the course of geographic atrophy. Exp. Eye Res. 2011; 93:413-423. http://dx.doi.org/10.1016/j.exer. 2011.06.002. [PubMed: 21684273]

Wallis R, Mitchell DA, Schmid R, Schwaeble WJ, Keeble AH. Paths reunited: initiation of the classical and lectin pathways of complement activation. Immunobiology. 2010; 215:1-11. http:// dx.doi.org/10.1016/j.imbio.2009.08.006. [PubMed: 19783065]

Wang G, Dubovy SR, Kovach JL, Schwartz SG, Agarwal A, Scott WK, Haines JL, Pericak-Vance MA. Variants at chromosome 10q26 locus and the expression of HTRA1 in the retina. Exp. Eye Res. 2013; 112:102-105. http://dx.doi.org/10.1016/j.exer.2013.04.019. [PubMed: 23644223]

Wang G, Scott WK, Whitehead P, Court BL, Kovach JL, Schwartz SG, Agarwal A, Dubovy S, Haines JL, Pericak-Vance MA. A novel ARMS2 splice variant is identified in human retina. Exp. Eye Res. 2012a; 94:187-191. http://dx.doi.org/10.1016/j.exer.2011.11.005. [PubMed: 22138417]

Wang G, Spencer KL, Court BL, Olson LM, Scott WK, Haines JL, Pericak-Vance MA. Localization of age-related macular degeneration-associated ARMS2 in cytosol, not mitochondria. Investig. Ophthalmol. Vis. Sci. 2009a; 50:3084-3090. http://dx.doi.org/10.1167/iovs.08-3240. [PubMed: 19255159]

Wang L, Clark ME, Crossman DK, Kojima K, Messinger JD, Mobley JA, Curcio CA. Abundant lipid and protein components of drusen. PLoS One. 2010a; 5:e10329. http://dx.doi.org/10.1371/ journal.pone.0010329. [PubMed: 20428236]

Wang L, Li C-M, Rudolf M, Belyaeva OV, Chung BH, Messinger JD, Kedishvili NY, Curcio CA. Lipoprotein particles of intraocular origin in human Bruch membrane: an unusual lipid profile. Investig. Ophthalmol. Vis. Sci. 2009b; 50:870-877. http://dx.doi.org/10.1167/iovs.08-2376. [PubMed: 18806290]

Wang M-Y, Ji S-R, Bai C-J, Kebir El D, Li H-Y, Shi J-M, Zhu W, Costantino S, Zhou H-H, Potempa LA, Zhao J, Filep JG, Wu Y. A redox switch in C-reactive protein modulates activation of 
endothelial cells. FASEB J. 2011; 25:3186-3196. http://dx.doi.org/10.1096/fj.11-182741. [PubMed: 21670067]

Wang MY, Rousseau J, Boisjoly H, Schmaltz H, Kergoat M-J, Moghadaszadeh S, Djafari F, Freeman EE. Activity limitation due to a fear of falling in older adults with eye disease. Investig. Ophthalmol. Vis. Sci. 2012b; 53:7967-7972. http://dx.doi.org/10.1167/iovs.12-10701. [PubMed: 23132799]

Wang Q, Chappell RJ, Klein R, Eisner A, Klein BE, Jensen SC, Moss SE. Pattern of age-related maculopathy in the macular area. The Beaver Dam Eye Study. Investig. Ophthalmol. Vis. Sci. 1996; 37:2234-2242.

Wang S, Linsenmeier RA. Hyperoxia improves oxygen consumption in the detached feline retina. Investig. Ophthalmol. Vis. Sci. 2007; 48:1335-1341. http://dx.doi.org/10.1167/iovs.06-0842. [PubMed: 17325181]

Wang Y, Bian Z-M, Yu W-Z, Yan Z, Chen W-C, Li X-X. Induction of interleukin-8 gene expression and protein secretion by C-reactive protein in ARPE-19 cells. Exp. Eye Res. 2010b; 91:135-142. http://dx.doi.org/10.1016/j.exer.2010.02.008. [PubMed: 20188089]

Wangsa-Wirawan ND, Linsenmeier RA. Retinal oxygen: fundamental and clinical aspects. Arch. Ophthalmol. 2003; 121:547-557. http://dx.doi.org/10.1001/archopht.121.4.547. [PubMed: 12695252]

Weber BH, Vogt G, Pruett RC, Stohr H, Felbor U. Mutations in the tissue inhibitor of metalloproteinases-3 (TIMP3) in patients with Sorsby's fundus dystrophy. Nat. Genet. 1994; 8:352-356. http://dx.doi.org/10.1038/ng1294-352. [PubMed: 7894485]

Weeks DE, Conley YP, Tsai HJ, Mah TS, Rosenfeld PJ, Paul TO, Eller AW, Morse LS, Dailey JP, Ferrell RE, Gorin MB. Age-related maculopathy: an expanded genome-wide scan with evidence of susceptibility loci within the 1q31 and 17q25 regions. Am. J. Ophthalmol. 2001; 132:682-692. [PubMed: 11704029]

Weismann D, Hartvigsen K, Lauer N, Bennett KL, Scholl HPN, Charbel Issa P, Cano M, Brandstätter H, Tsimikas S, Skerka C, Superti-Furga G, Handa JT, Zipfel PF, Witztum JL, Binder CJ. Complement factor $\mathrm{H}$ binds malondialdehyde epitopes and protects from oxidative stress. Nature. 2011; 478:76-81. http://dx.doi.org/10.1038/nature10449. [PubMed: 21979047]

Whitmore SS, Braun TA, Skeie JM, Haas CM, Sohn EH, Stone EM, Scheetz TE, Mullins RF. Altered gene expression in dry age-related macular degeneration suggests early loss of choroidal endothelial cells. Mol. Vis. 2013; 19:2274-2297. [PubMed: 24265543]

Wolf-Schnurrbusch UEK, Enzmann V, Brinkmann CK, Wolf S. Morphologic changes in patients with geographic atrophy assessed with a novel spectral OCT-SLO combination. Investig. Ophthalmol. Vis. Sci. 2008; 49:3095-3099. http://dx.doi.org/10.1167/iovs.07-1460. [PubMed: 18378583]

Yang Z, Camp NJ, Sun H, Tong Z, Gibbs D, Cameron DJ, Chen H, Zhao Y, Pearson E, Li X, Chien J, Dewan A, Harmon J, Bernstein PS, Shridhar V, Zabriskie NA, Hoh J, Howes K, Zhang K. A variant of the HTRA1 gene increases susceptibility to age-related macular degeneration. Science. 2006; 314:992-993. http://dx.doi.org/10.1126/science.1133811. [PubMed: 17053109]

Yasuma TR, Nakamura M, Nishiguchi KM, Kikuchi M, Kaneko H, Niwa T, Hamajima N, Terasaki H. Elevated C-reactive protein levels and ARMS2/HTRA1 gene variants in subjects without agerelated macular degeneration. Mol. Vis. 2010; 16:2923-2930. [PubMed: 21203342]

Yates JRW, Sepp T, Matharu BK, Khan JC, Thurlby DA, Shahid H, Clayton DG, Hayward C, Morgan J, Wright AF, Armbrecht AM, Dhillon B, Deary IJ, Redmond E, Bird AC, Moore AT, Genetic Factors in AMD Study Group. Complement C3 variant and the risk of age-related macular degeneration. N. Engl. J. Med. 2007; 357:553-561. http://dx.doi.org/10.1056/NEJMoa072618. [PubMed: 17634448]

Yu W, Dong S, Zhao C, Wang H, Dai F, Yang J. Cumulative association between age-related macular degeneration and less studied genetic variants in PLEKHA1/ARMS2/HTRA1: a meta and genecluster analysis. Mol. Biol. Rep. 2013; 40:5551-5561. http://dx.doi.org/10.1007/ s11033-013-2656-6. [PubMed: 24013816]

Yu, Y.; Triebwasser, MP.; Wong, EKS.; Schramm, EC.; Thomas, B.; Reynolds, R.; Mardis, ER.; Atkinson, JP.; Daly, M.; Raychaudhuri, S.; Kavanagh, D.; Seddon, JM. Whole-exome sequencing identifies rare, functional $\mathrm{CFH}$ variants in families with macular degeneration.. Hum. Mol. Genet. 2014. http://dx.doi.org/10.1093/hmg/ddu226. 
Yuan X, Gu X, Crabb JS, Yue X, Shadrach K, Hollyfield JG, Crabb JW. Quantitative proteomics: comparison of the macular Bruch membrane/choroid complex from age-related macular degeneration and normal eyes. Mol. Cell Proteomics. 2010; 9:1031-1046. http://dx.doi.org/ 10.1074/mcp.M900523-MCP200. [PubMed: 20177130]

Zalman LS, Muller-Eberhard HJ. Comparison of channels formed by poly C9, C5b-8 and the membrane attack complex of complement. Mol. Immunol. 1990; 27:533-537. [PubMed: 1696352]

Zamora DO, Riviere M, Choi D, Pan Y, Planck SR, Rosenbaum JT, David LL, Smith JR. Proteomic profiling of human retinal and choroidal endothelial cells reveals molecular heterogeneity related to tissue of origin. Mol. Vis. 2007; 13:2058-2065. [PubMed: 18079679]

Zareparsi S, Branham KEH, Li M, Shah S, Klein RJ, Ott J, Hoh J, Abecasis GR, Swaroop A. Strong association of the $\mathrm{Y} 402 \mathrm{H}$ variant in complement factor $\mathrm{H}$ at $1 \mathrm{q} 32$ with susceptibility to agerelated macular degeneration. Am. J. Hum. Genet. 2005; 77:149-153. http://dx.doi.org/ 10.1086/431426. [PubMed: 15895326]

Zeng F, Zhang M, Xu Y, Xu H. ARMS2 interference leads to decrease of proinflammatory mediators. Graefes Arch. Clin. Exp. Ophthalmol. 2013; 251:2539-2544. http://dx.doi.org/10.1007/ s00417-013-2442-0. [PubMed: 23959158]

Zeng S, Hernandéz JJ, Mullins RF. Effects of antioxidant components of AREDS vitamins and zinc ions on endothelial cell activation: implications for macular degeneration. Investig. Ophthalmol. Vis. Sci. 2012; 53:1041-1047. http://dx.doi.org/10.1167/iovs.11-8531. [PubMed: 22247465]

Zhan, X.; Larson, DE.; Wang, C.; Koboldt, DC.; Sergeev, YV.; Fulton, RS.; Fulton, LL.; Fronick, CC.; Branham, KE.; Bragg-Gresham, J.; Jun, G.; Hu, Y.; Kang, HM.; Liu, D.; Othman, M.; Brooks, M.; Ratnapriya, R.; Boleda, A.; Grassmann, F.; Strachwitz von, C.; Olson, LM.; Buitendijk, GHS.; Hofman, A.; van Duijn, CM.; Cipriani, V.; Moore, AT.; Shahid, H.; Jiang, Y.; Conley, YP.; Morgan, DJ.; Kim, IK.; Johnson, MP.; Cantsilieris, S.; Richardson, AJ.; Guymer, RH.; Luo, H.; Ouyang, H.; Licht, C.; Pluthero, FG.; Zhang, MM.; Zhang, K.; Baird, PN.; Blangero, J.; Klein, ML.; Farrer, LA.; Deangelis, MM.; Weeks, DE.; Gorin, MB.; Yates, JRW.; Klaver, CCW.; Pericak-Vance, MA.; Haines, JL.; Weber, BHF.; Wilson, RK.; Heckenlively, JR.; Chew, EY.; Stambolian, D.; Mardis, ER.; Swaroop, A.; Abecasis, GR. Identification of a rare coding variant in complement 3 associated with age-related macular degeneration.. Nat. Genet. 2013. http://dx.doi.org/10.1038/ng.2758

Zhang H, Morrison MA, DeWan A, Adams S, Andreoli M, Huynh N, Regan M, Brown A, Miller JW, Kim IK, Hoh J, Deangelis MM. The NEI/NCBI dbGAP database: genotypes and haplotypes that may specifically predispose to risk of neovascular age-related macular degeneration. BMC Med. Genet. 2008; 9:51. http://dx.doi.org/10.1186/1471-2350-9-51. [PubMed: 18541031]

Zhang L, Lee K, Niemeijer M, Mullins RF, Sonka M, Abramoff MD. Automated segmentation of the choroid from clinical SD-OCT. Investig. Ophthalmol. Vis. Sci. 2012a; 53:7510-7519. http:// dx.doi.org/10.1167/iovs.12-10311. [PubMed: 23060139]

Zhang L, Lim SL, Du H, Zhang M, Kozak I, Hannum G, Wang X, Ouyang H, Hughes G, Zhao L, Zhu X, Lee C, Su Z, Zhou X, Shaw R, Geum D, Wei X, Zhu J, Ideker T, Oka C, Wang N, Yang Z, Shaw PX, Zhang K. High temperature requirement factor A1 (HTRA1) gene regulates angiogenesis through transforming growth factor- $\beta$ family member growth differentiation factor 6. J. Biol. Chem. 2012b; 287:1520-1526. http://dx.doi.org/10.1074/jbc.M111.275990. [PubMed: 22049084]

Zipfel PF, Skerka C. Complement regulators and inhibitory proteins. Nat. Rev. Immunol. 2009; 9:729_ 740. http://dx.doi.org/10.1038/nri2620. [PubMed: 19730437]

Zweifel SA, Imamura Y, Spaide TC, Fujiwara T, Spaide RF. Prevalence and significance of subretinal drusenoid deposits (reticular pseudodrusen) in age-related macular degeneration. Ophthalmology. 2010a; 117:1775-1781. http://dx.doi.org/10.1016/j.ophtha.2010.01.027. [PubMed: 20472293]

Zweifel SA, Spaide RF, Curcio CA, Malek G, Imamura Y. Reticular pseudodrusen are subretinal drusenoid deposits. Ophthalmology. 2010b; 117:303-312. e1. http://dx.doi.org/10.1016/j.ophtha. 2009.07.014. [PubMed: 19815280] 


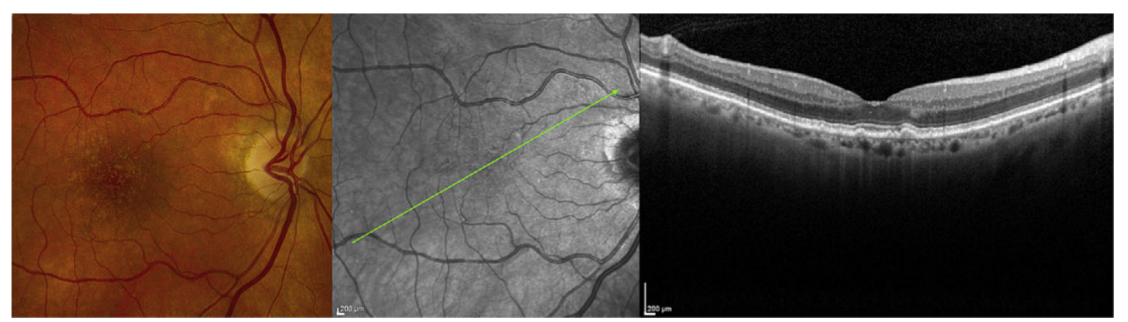

Fig. 1.

Clinical appearance of drusen. Images of the right fundus of a 78 year old Caucasian female. Left panel, photograph demonstrating numerous macular drusen of various sizes; middle panel, infrared image showing location of optical coherence tomography scan in right panel indicating the sub-RPE location corresponding to drusen. 


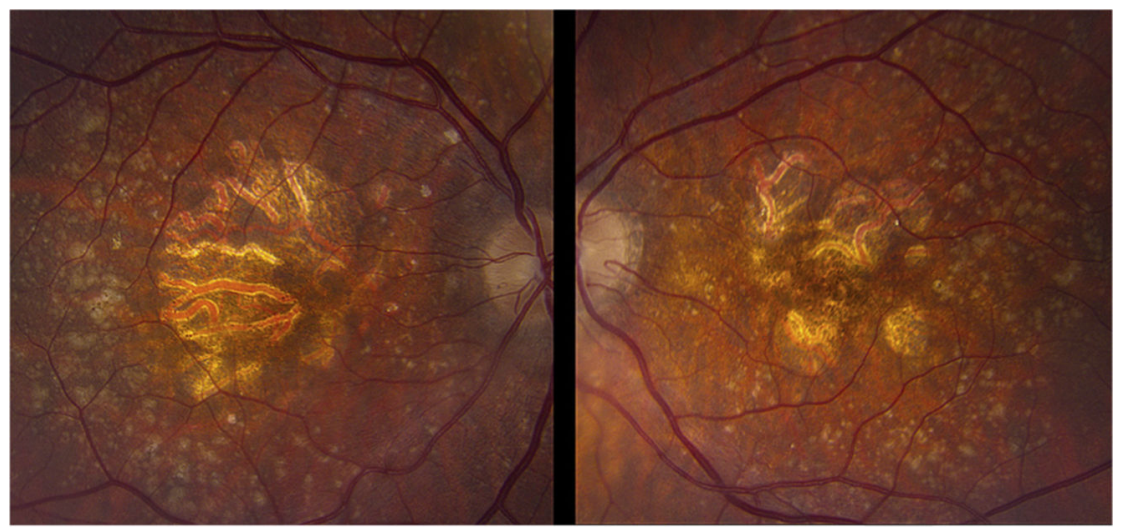

Fig. 2.

Clinical appearance of geographic atrophy. Fundus of an 88 year old Caucasian female. Left panel shows the right fundus (VA 20/100) with geography atrophy in the center of the macula with surrounding drusen, the largest of which are prominent in the temporal macula. Notice the confluence of the GA in this eye compared to the Right panel where the GA rings the fovea of the left eye (VA 20/40) in nummular fashion with similarly prominent drusen in peripheral macula. 


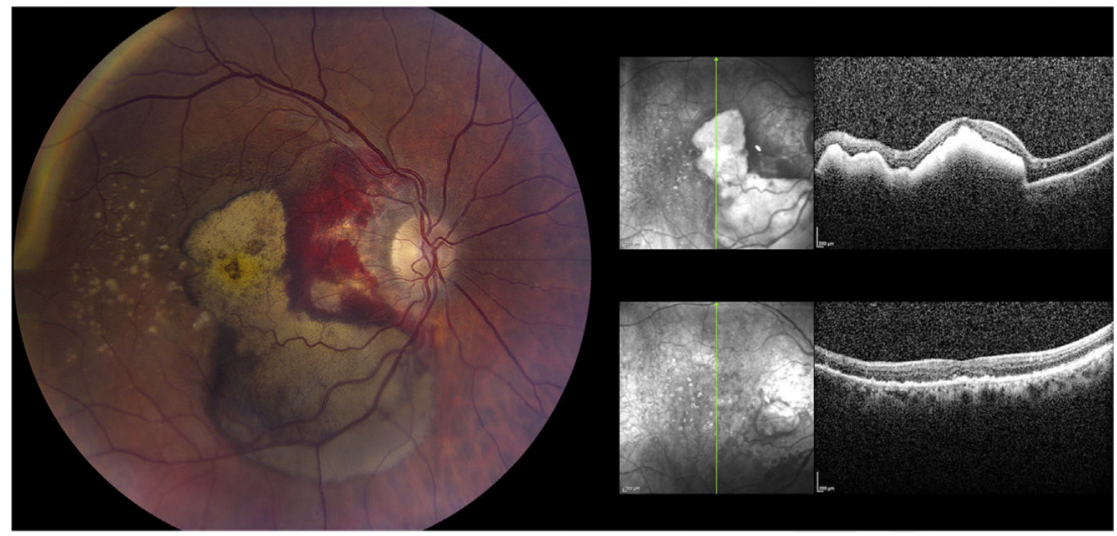

Fig. 3.

Choroidal neovascularization. Images of 87 year old male with neovascular AMD of the right eye (VA 20/150). Upon presentation (left panel) there was prominent blood in the macula that was already dehemoglobinizing in the fovea and inferior macula corresponding to hyperreflective material on OCT (right upper panel). 3 months after anti-VEGF injections the blood has largely resolved (right lower panel) but VA is 20/100 due to atrophy of the outer retina. 


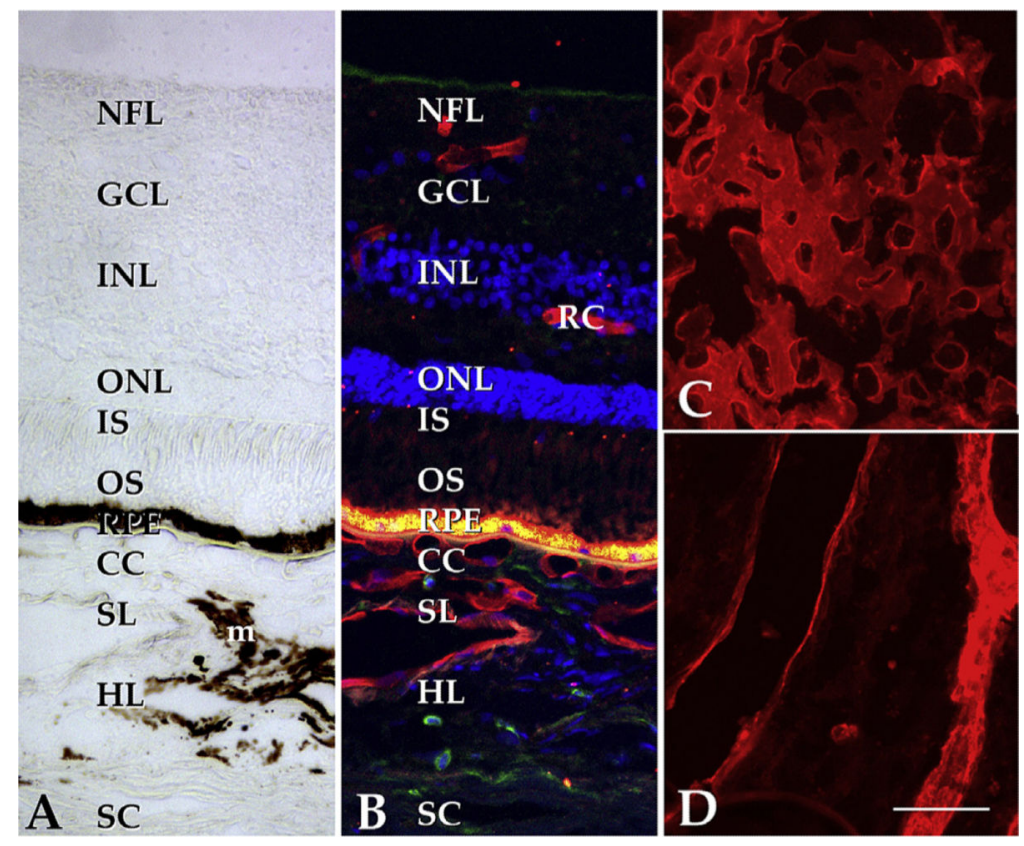

Fig. 4.

Structure of the human macula. (A) Brightfield image of the extrafoveal macula; in normal eyes, the neural retina, RPE and choroid exist as an interdependent unit. Light enters the retina from the top of the panel, penetrates the inner retina and excites photoreceptor cell outer segments (OS). Stray photons are absorbed by melanosomes in the RPE and choroidal melanocytes $(\mathrm{m})$. The phototransduction cascade results in arrest of glutamate release from photoreceptor cells and the excitation of neurons in the inner nuclear layer (INL), which in turn excite the ganglion cells (GC) that elaborate axons to the brain. The choroid itself is divided into the choriocapillaris (CC), Sattler's layer (SL), Haller's layer (HL), and the suprachoroidea, adjacent to the sclera (SC). Whereas the choriocapillaris is the vascular supply for the photoreceptor cells and RPE, the inner retina has its own vascular network (retinal capillaries, RC). B, same field as A shown with UEA-I (red), anti-CD45 antibody (green) and the nuclear stain DAPI (blue). Note the labeling of retinal and choroidal endothelial cells. The intense fluorescence at the level of the RPE is due to lipofuscin autofluorescence. C, flat section through the choriocapillaris layer shows dense, anastomosing network of large caliber capillaries (UEA-I, red); D, deeper section through the outer choroid. Scalebar, $50 \mu \mathrm{m}$. 

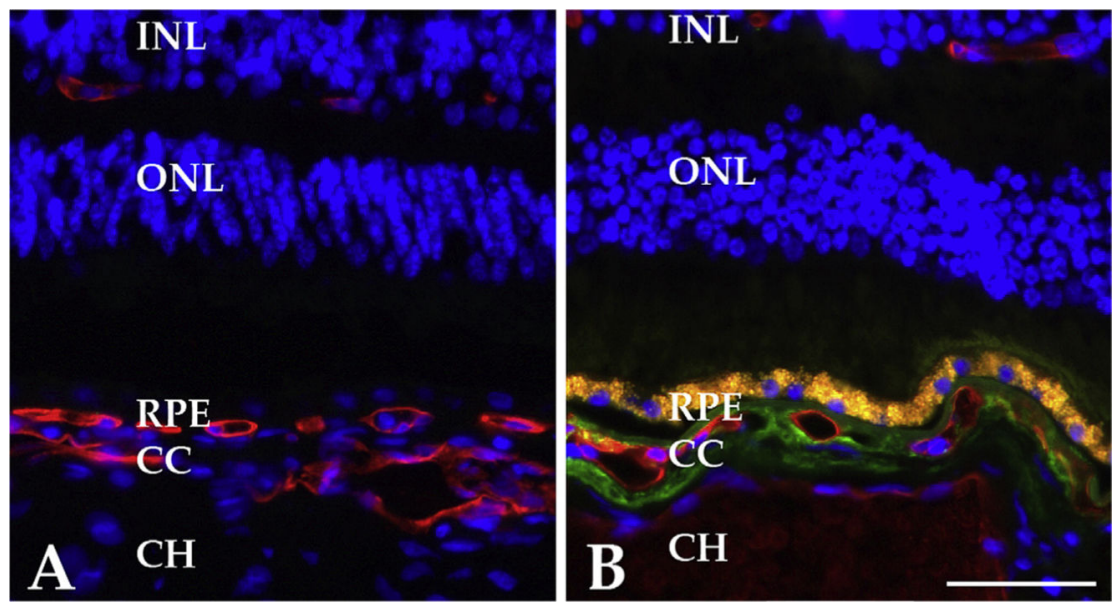

Fig. 5.

Accumulation of the membrane attack complex in aging. Anti-MAC antibody is shown in green, UEA-I lectin is depicted in red. A, section of newborn donor without MAC immunoreactivity; B, section of 79 year old donor with extensive MAC immunoreactivity in the choriocapillaris. ELISA analyses show increased MAC in aging and additional increased MAC in AMD (see e.g. Mullins et al., in press AJP). Scalebar, $50 \mu \mathrm{m}$. 


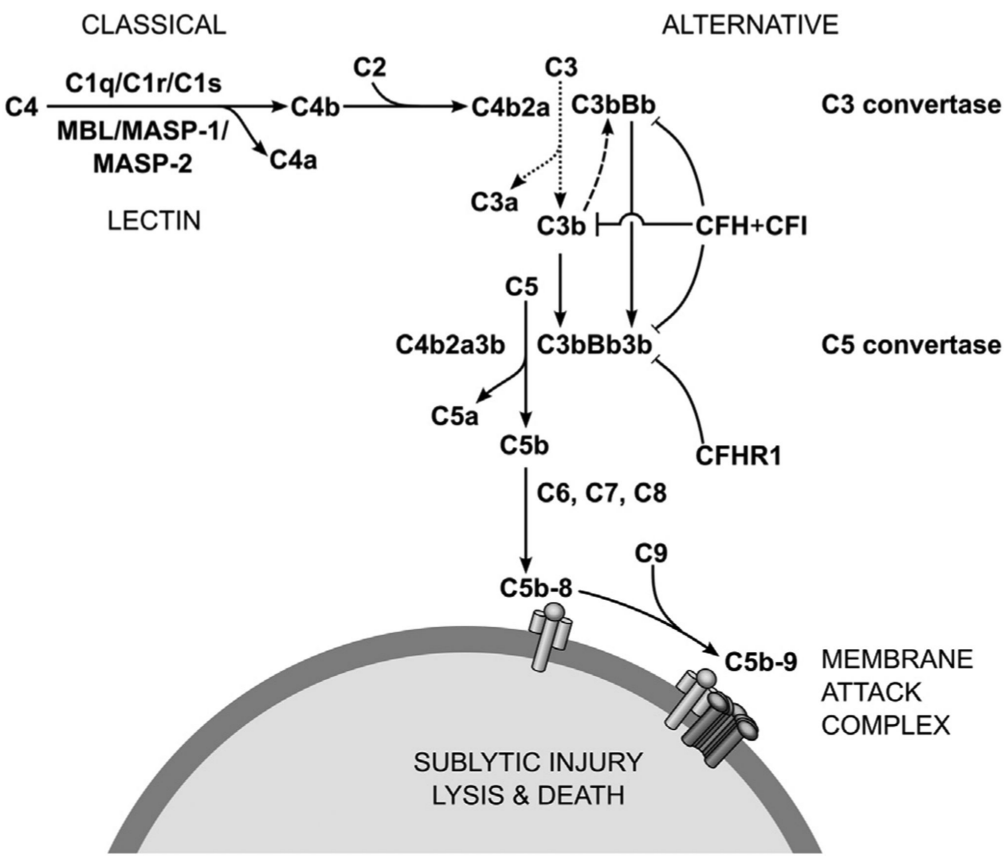

Fig. 6.

Diagram showing some of the key elements of the complement cascade. In the classical pathway, initiation occurs when $\mathrm{C} 1 \mathrm{q}$ binds to $\mathrm{IgG}$ or IgM immune complexes. The lectin pathway engages when mannose-binding lectin (MBL) binds pathogen associated carbohydrate moieties, such as mannose or glucose. In the alternative pathway, C3 spontaneously hydrolyzes (dotted line) but negative regulators (e.g., $\mathrm{CFH}$ and $\mathrm{CFI}$ ) bound to the extracellular matrix of host cells prevent amplifying cleavage of $\mathrm{C} 3$ by $\mathrm{C} 3 \mathrm{~b}$ (dashed line). Without binding opportunities for $\mathrm{CFH}$, as on bacterial cell walls, positive feedback occurs ultimately leading to MAC deposition. Figure adapted from Thurman and Holers (2006). 


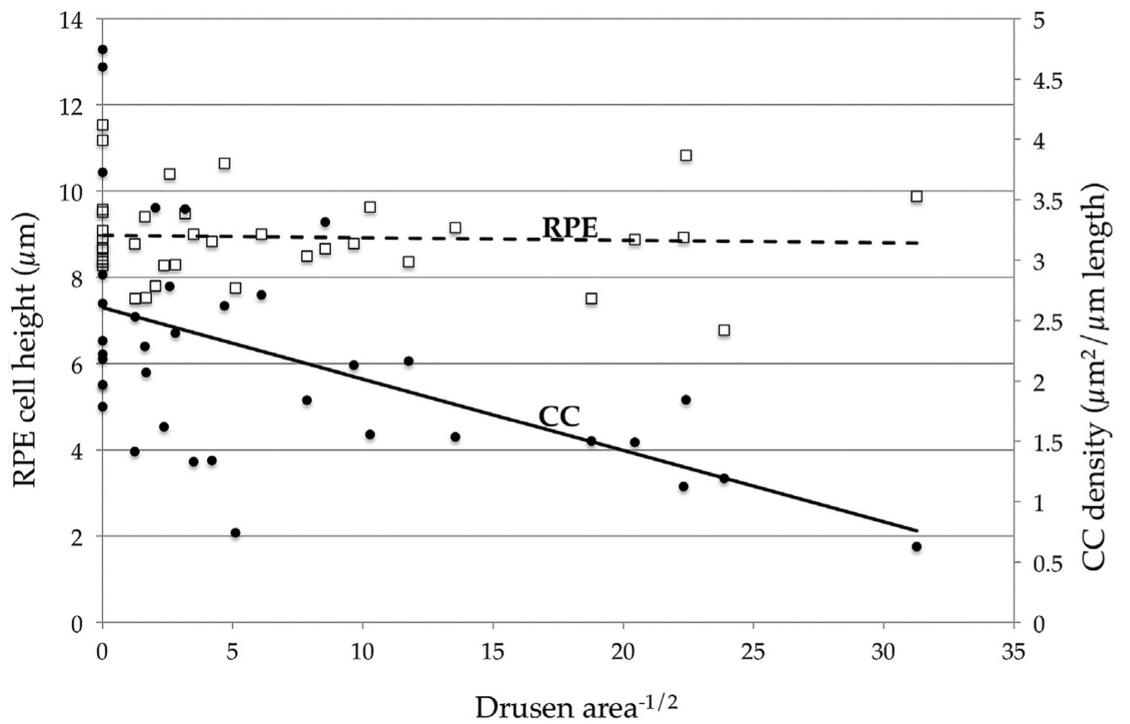

Fig. 7.

Quantitative measurements of subRPE deposits and vascular density in human eyes. Linear regression analysis performed on a series of human donors shows that increasing size and/or number of drusen was negatively correlated with vascular density (filled circles/solid trendline; $\left.r^{2}=0.22, P<0.01\right)$. In contrast, the height of the RPE (open squares, dashed line) was not correlated with drusen density. Adapted from Mullins et al. (2011b). 

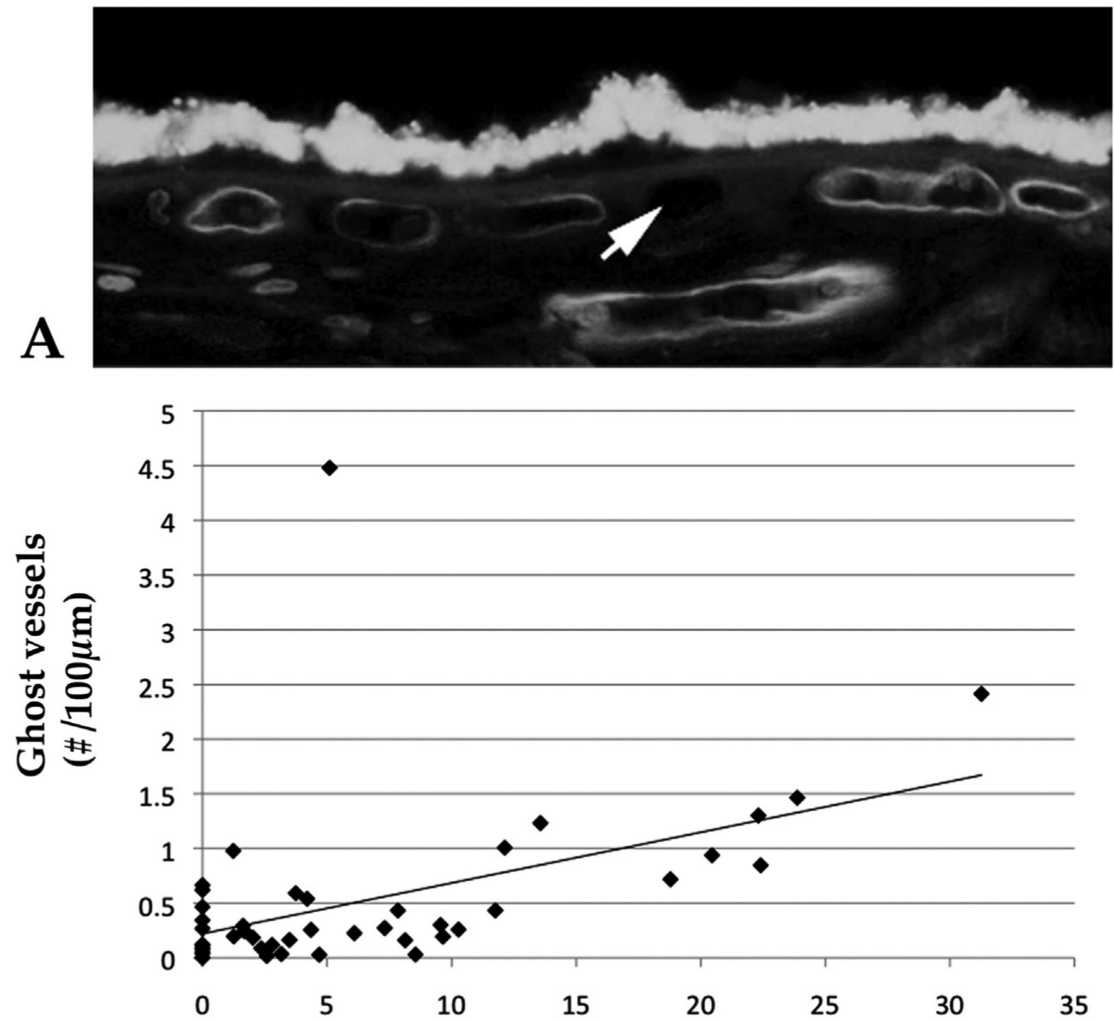

B

Drusen density $(\mu \mathrm{m} 2 / \mu \mathrm{m})-1 / 2$

Fig. 8.

Ghost vessels in the choriocapillaris are associated with pathologic subRPE deposits in AMD. A, Section of human macula labeled with UEA-I lectin shows two healthy vessels (asterisks) surrounding a UEA-I negative ghost vessel (asterisk). B, Linear regression analysis of numbers of ghost vessels versus the square root of drusen density. Drusen and ghost vessels showed a strong positive correlation $\left(r^{2}=0.57\right.$, corrected $\left.P<0.001\right)$. Adapted from Mullins et al. (2011b). 


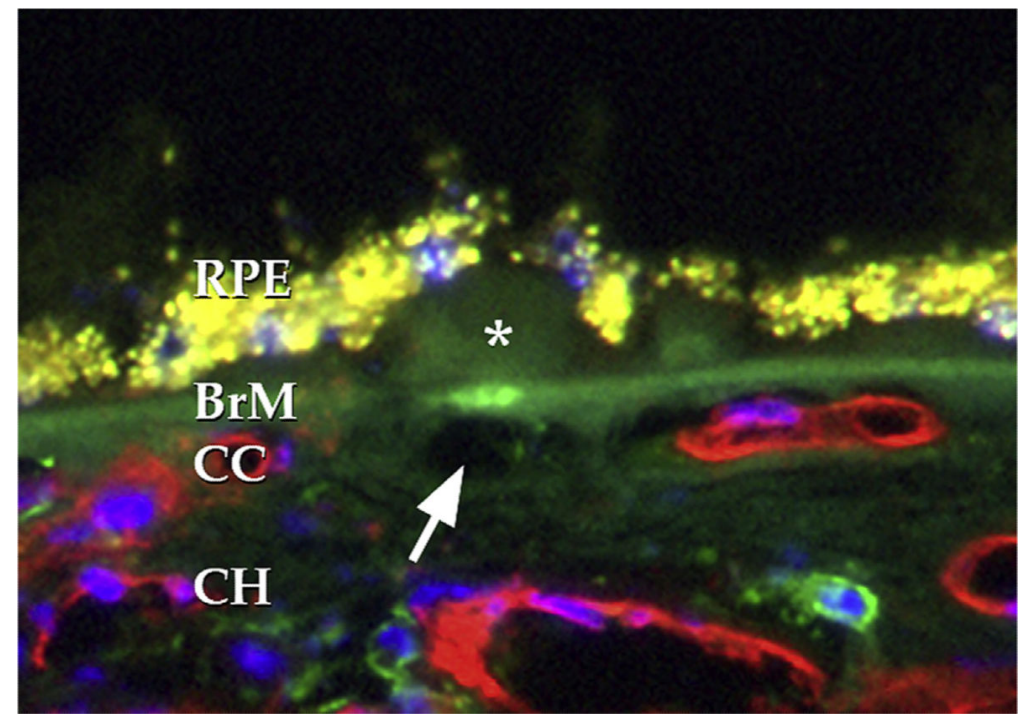

Fig. 9.

In addition to being more abundant in eyes in association with an increasing volume of drusen, ghost vessels appear to be frequently spatially associated with drusen as well. Section of human macula labeled with UEA-I lectin (red) and anti-CD45 antibody (green). Druse (asterisk) appears centered over choriocapillaris ghost (arrow). See also Sohn and Mullins, 2012, “Age Related Macular Degeneration - The Recent Advances in Basic Research and Clinical Care", Gui-Shuang Ying, editor. 

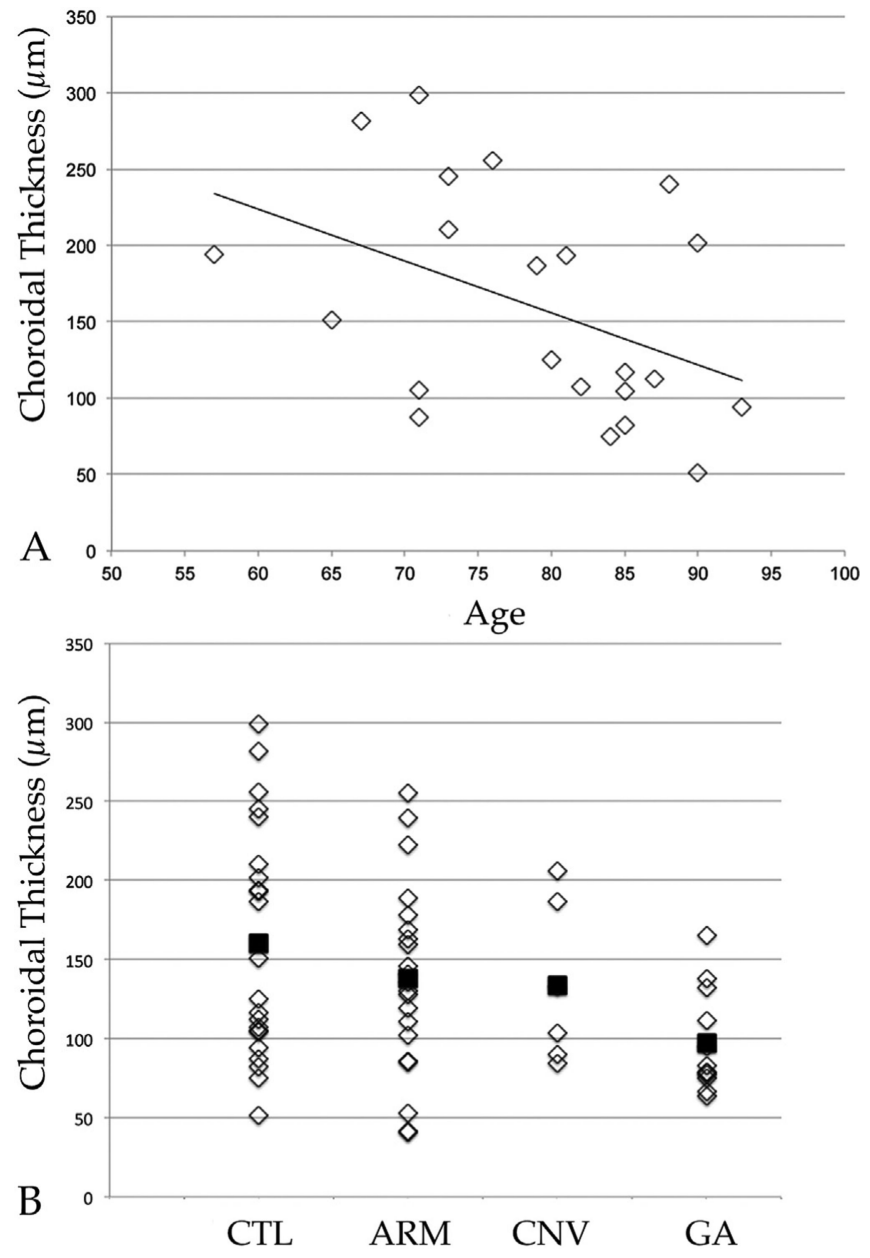

Fig. 10.

Effects of age and AMD on choroidal thickness. (A) Scatter plot of age (x-axis) and choroidal thickness ( $y$-axis) of 22 eyes without AMD. Among the non-AMD samples included in this study, age showed a statistically significant negative relationship to thickness (slope $P<0.05$ ), although the correlation was weak $\left(r^{2}=0.19\right)$. (B) Donor maculae were categorized as controls (CTL), early/dry AMD (ARM), neovascular AMD $(\mathrm{CNV})$, or geographic atrophy (GA). Eyes with geographic atrophy showed significant choroidal thinning compared to the other categories $(P<0.05)$. Diamonds indicate individuals, and filled squares indicate averages for each category. From Sohn et al. (2014b). 


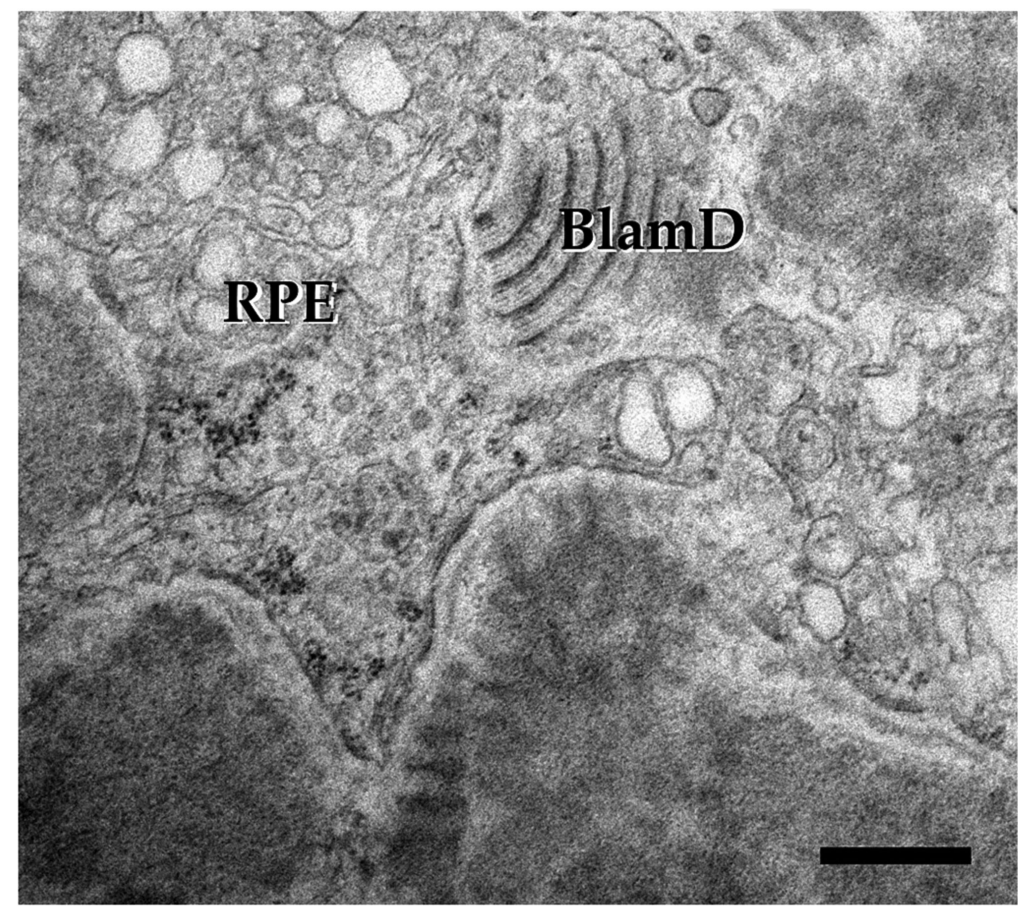

Fig. 11.

Ultrastructural appearance of basal laminar deposits in a human eye with geographic atrophy. Note the characteristic banded pattern with reproducible periodicity. These deposits typically form beneath the RPE, between the plasma membrane and basal lamina. Scalebar = $500 \mathrm{~nm}$.

Prog Retin Eye Res. Author manuscript; available in PMC 2016 March 01. 

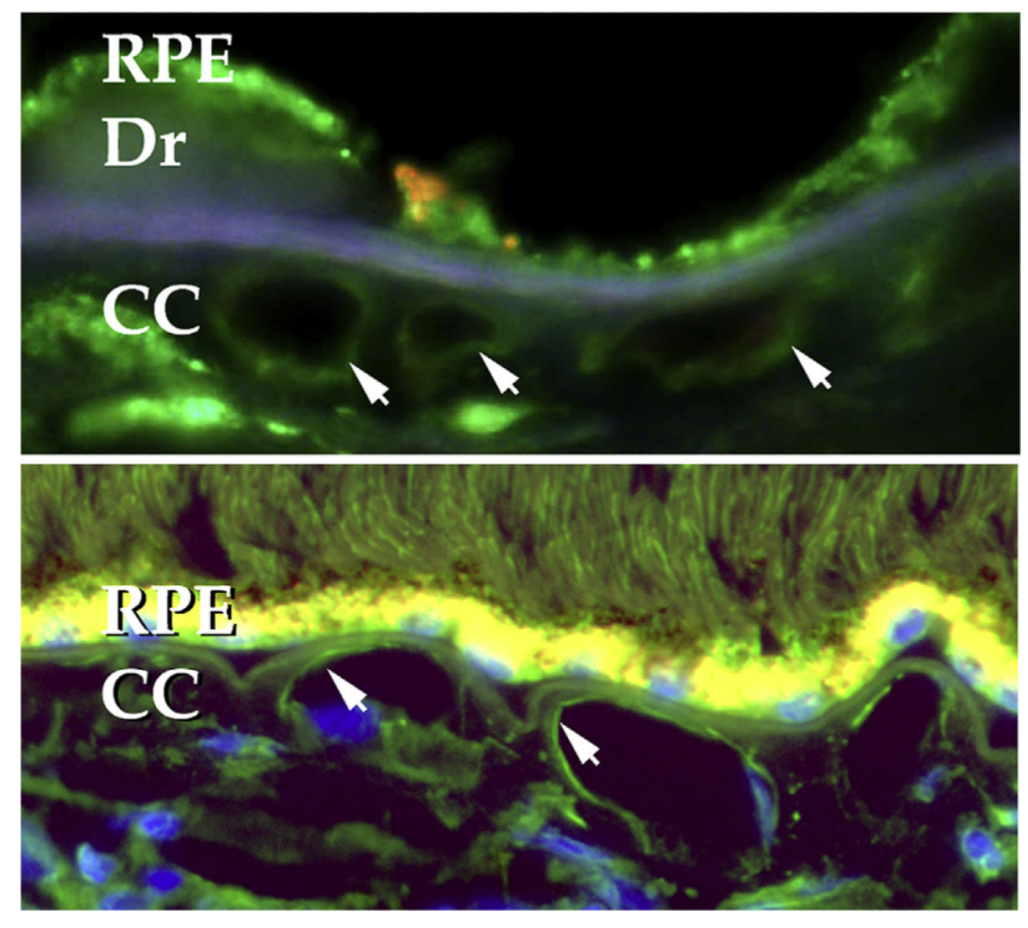

Fig. 12.

The human choriocapillaris has functional binding sites for LDL. Top, While the major site of LDL uptake is in choroidal macrophages, organ cultures of RPE/choroid exposed to fluorescent LDL show uptake in the choriocapillaris (CC), arrows. Bottom,

Immunohistochemistry with anti-LDL receptor antibodies show labeling in choriocapillaris endothelial cells (CC, arrows), Dr, druse. See also Tserentsoodol et al. (2006). 


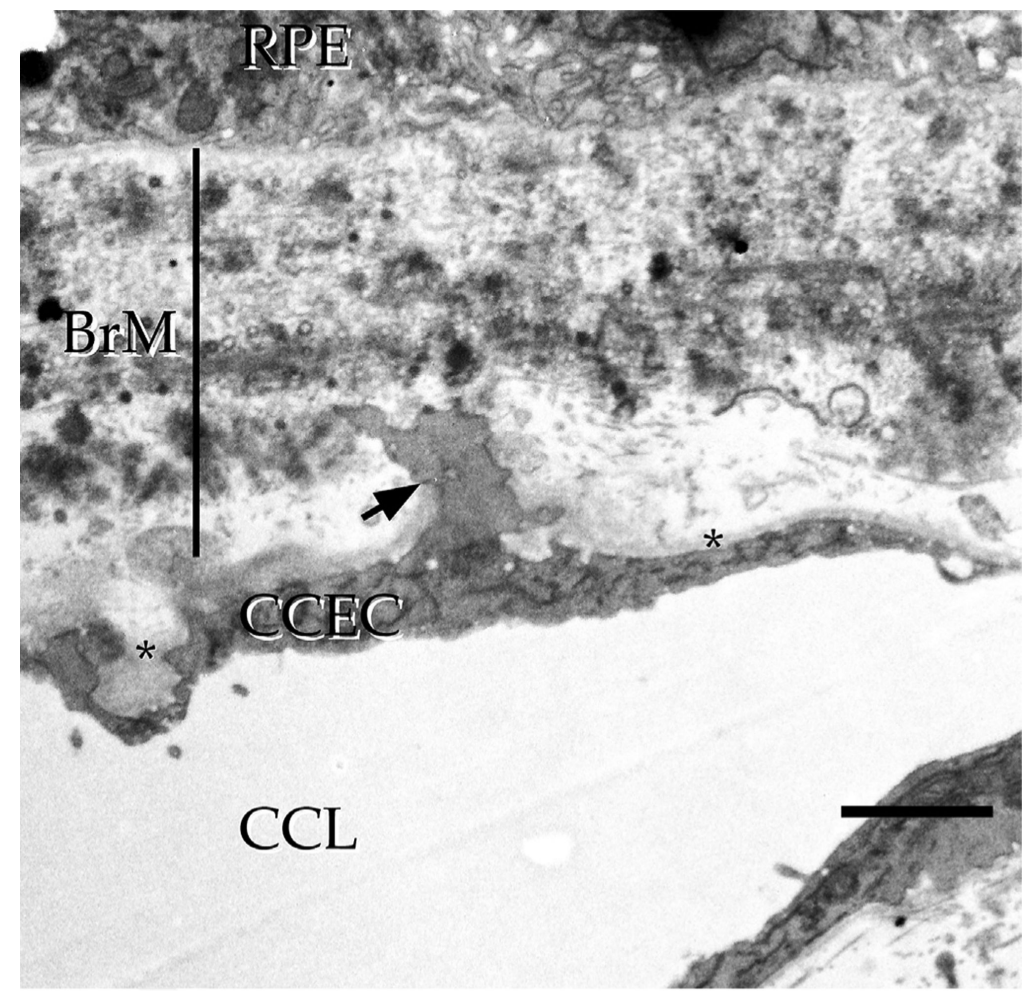

Fig. 13.

Choriocapillaris endothelial cells elaborate processes (arrow) that project into Bruch's membrane, where they presumably serve synthetic and/or degradative functions. Loss of choriocapillaris vasculature inevitably results in loss of this function. Figure shows a transmission electron micrograph of the extramacular region of a 77 year old human donor eye. BrM, Bruch's membrane; CCEC, choriocapillaris endothelial cell; CCL, choriocapillaris lumen. Asterisk, choriocapillaris basal lamina; scalebar $=2 \mu \mathrm{m}$. 

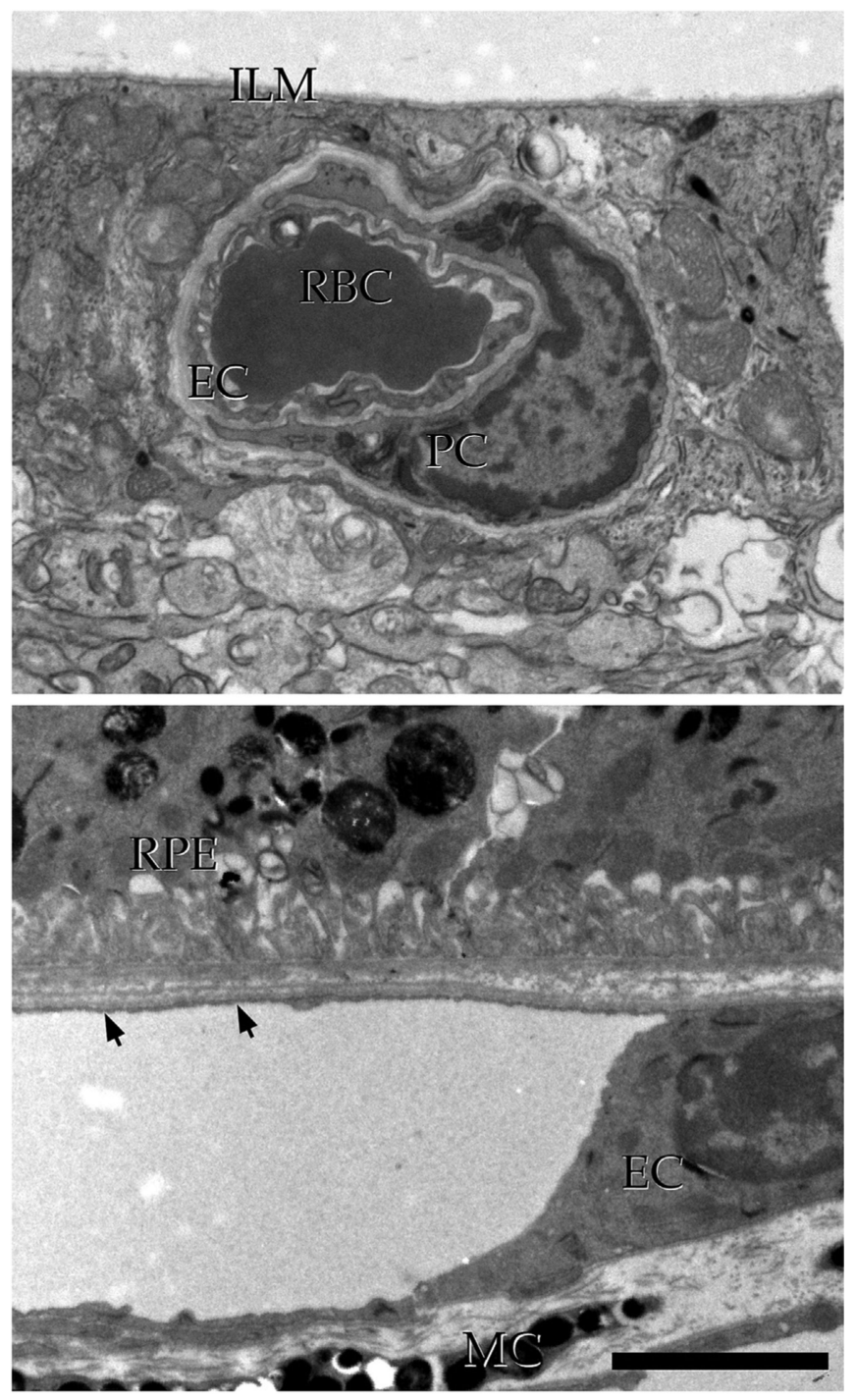

Fig. 14.

Ultrastructural comparison of endothelial cells (EC) of the retinal vasculature (top) and choriocapillaris (bottom) in mouse. In the retina, note the small diameter of the vessel, that narrowly permits the passage of a red blood cell (RBC). The retinal endothelium has relatively abundant cytosol, tight junctions (arrowhead), and a basal lamina. These capillaries are surrounded by pericytes (PC) which also have their own basal lamina and dark-staining glial processes. In contrast, choriocapillary endothelial cells (bottom) show a very small distance between their lumen and the extravascular space, especially on the surface facing the RPE basal infoldings. The inner surface of these cells is also typically fenestrated, giving the appearance of beads on a strong (arrows). A choroidal melanocyte (MC) is also depicted. Scalebar $=2 \mu \mathrm{m}$. 


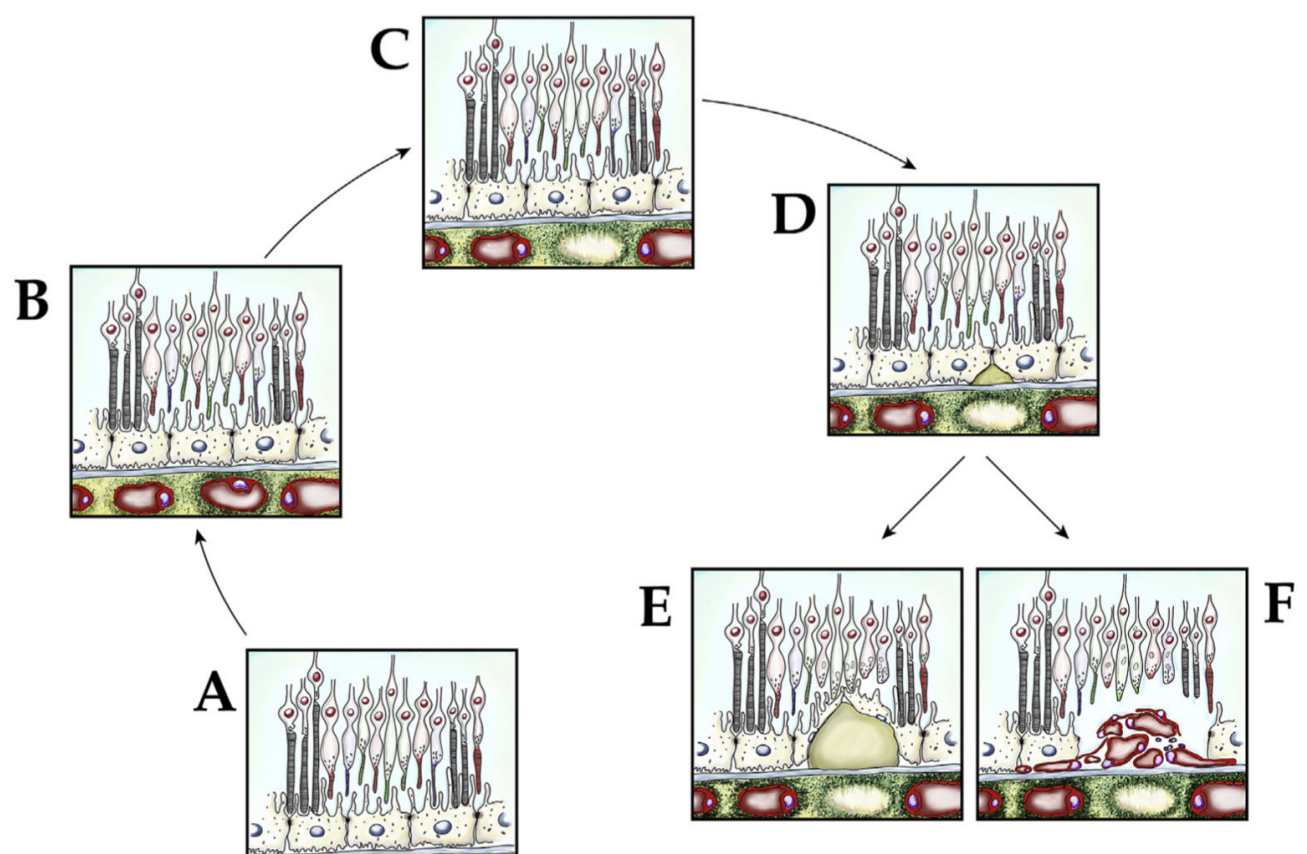

Fig. 15.

Schematic diagram depicting the proposed pathological processes involved in the development and progression of AMD. In a young macula (A), photoreceptor cells are supported by the RPE and choriocapillaris. During normal aging (B), MAC (green profiles) accumulates in Bruch's membrane and the choriocapillaris. The continuous exposure to MAC, especially in eyes with high-risk CFH genotypes, leads to loss of choriocapillaris endothelial cells and formation of ghost vessels (C). Impaired clearance, increased hypoxia or other events lead to increased deposition of drusen (D), which can lead to further atrophy (E) or choroidal neovascularization $(F)$. 